\title{
THE FUTURE OF THE JUDICIAL SYSTEM IN THE EUROPEAN UNION
}

\author{
Ulrich Walter Hoehler \\ McGill University, Montreal
}

March 2002

\begin{abstract}
A thesis submitted to the Faculty of Graduate Studies and Research in partial fulfilment of the requirements of the degree of Master of Laws.
\end{abstract}


National Library of Canada

Acquisitions and Bibliographic Services

395 Wellington Street Ottawa ON KIA ON4 Canada
Bibliothèque nationale du Canada

Acquisitions ef services bibliographiques

395, rue Wollingtion

Ottawa ON KIA ON4

Canada
Your 苚le Votra rélérence

Our the Natre rilarence
The author has granted a nonexclusive licence allowing the National Library of Canada to reproduce, loan, distribute or sell copies of this thesis in microform, paper or electronic formats.
L'auteur a accordé une licence non exclusive permettant à la Bibliothèque nationale du Canada de reproduire, prêter, distribuer ou vendre des copies de cette thèse sous la forme de microfiche/film, de reproduction sur papier ou sur format électronique.

L'auteur conserve la propriété du droit d'auteur qui protège cette thèse. copyright in this thesis. Neither the thesis nor substantial extracts from it may be printed or otherwise reproduced without the author's permission.
$\mathrm{Ni}$ la thèse ni des extraits substantiels de celle-ci ne doivent être imprimés ou autrement reproduits sans son autorisation. 


\section{Table of contents}

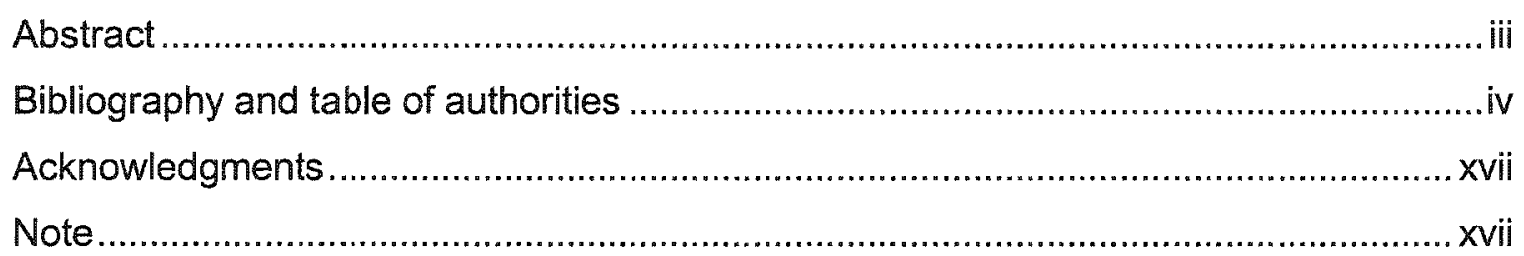

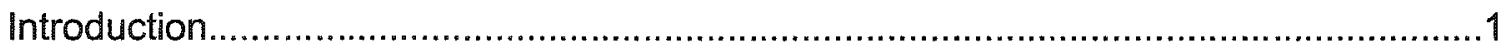

Part 1 History of the development of courts applying European Union law....................2

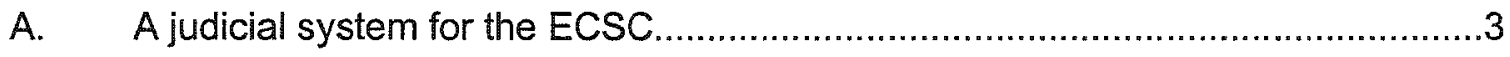

B. The emerging of a Court of Justice of the European Communities .....................4

C. Co-operation between the Court of Justice and the courts of the Member

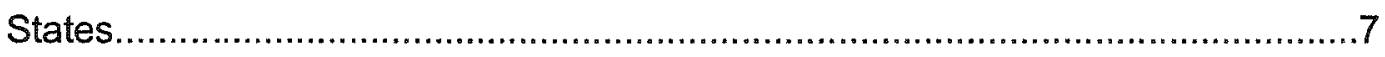

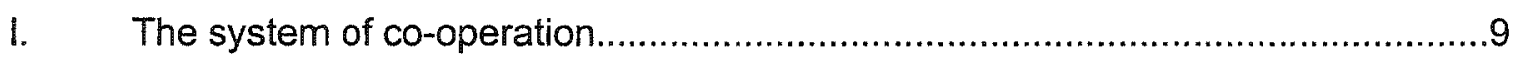

II. Remedies and procedure in the national courts........................................ 11

D. Development of the Court of Justice under the Treaties................................... 14

E. Secondary Community law and conventions concluded between the Member

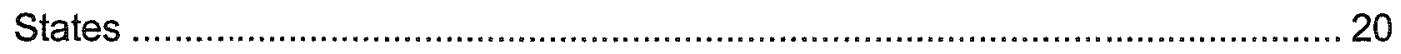

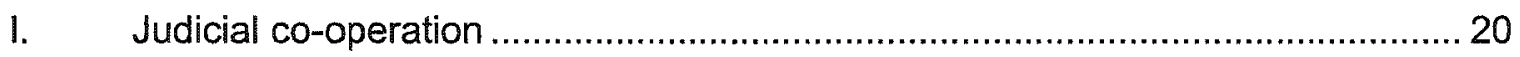

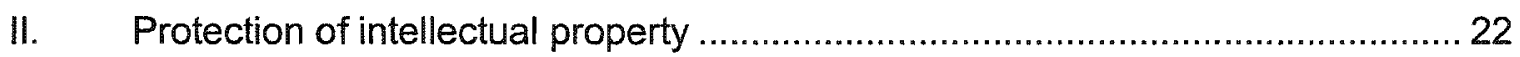

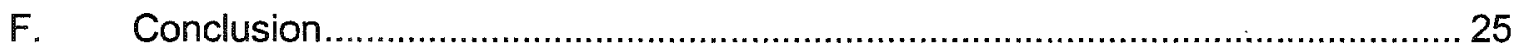

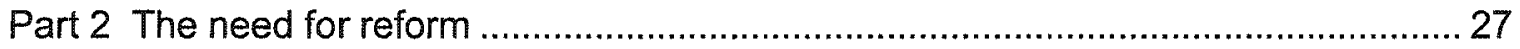

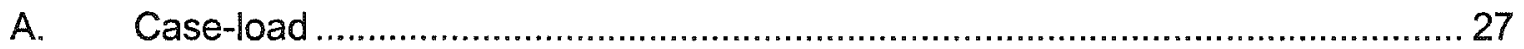

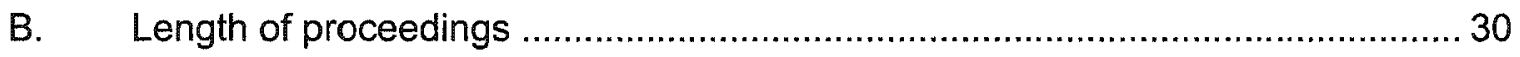

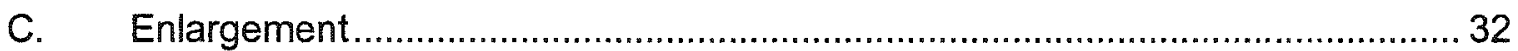

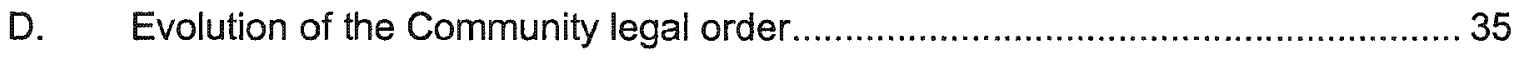

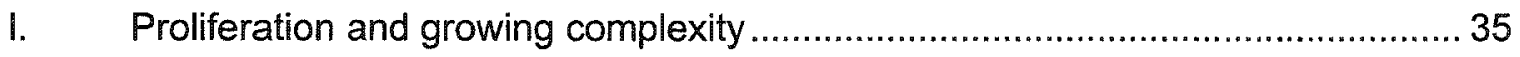

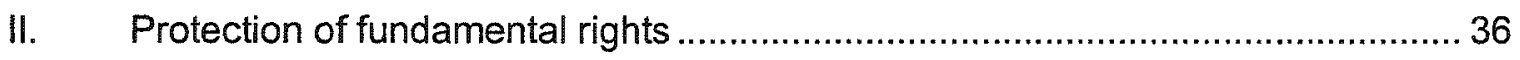

E. Conclusion - The need for structural reform ........................................... 38

Part 3 Identifying possible changes to the judicial structure ................................. 41 
A. Extending the competences of the court(s) of first instance ...........................42

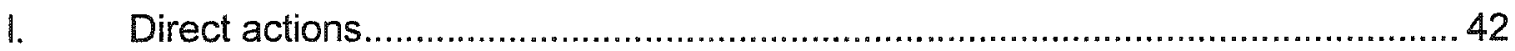

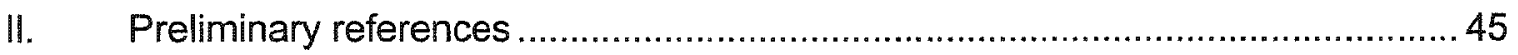

III. Standing of individuals to bring actions for annulment.................................. 48

IV. Opinions concerning international agreements .........................................49

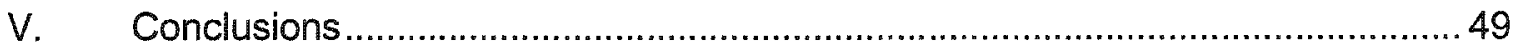

B. Mechanisms for limiting the flow of appeals to the Court of Justice ...................50

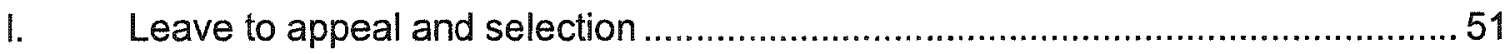

11. Appeals brought by Member States or Community institutions .........................5 53

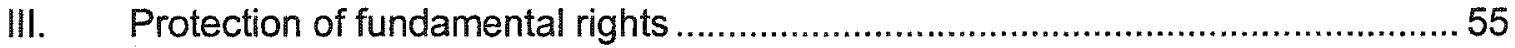

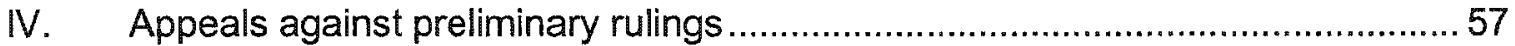

C. Increasing the responsibility of the courts of the Member States ......................58

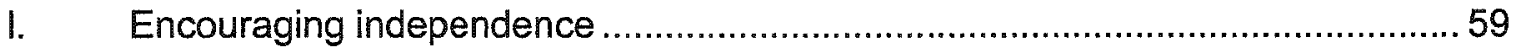

II. Submission of draft answers to the question referred ..................................61 61

III. Limiting the courts entitled to make preliminary references .............................6 62

IV. Selection of questions by the Court of Justice ............................................ 64

V. Designation of decentralised judicial bodies with limited jurisdiction to rule on

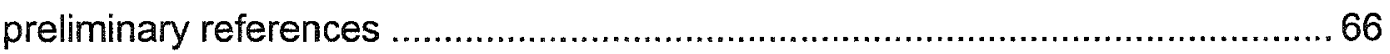

D. Institutionalising chambers; creation of specialised tribunals .........................68

I. Court divisions and the principle of representation .......................................6 68

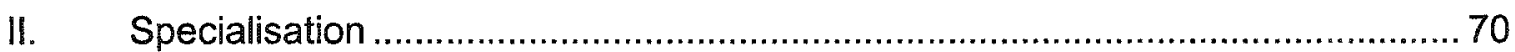

III. Tribunals below the Court of First Instance ................................................... 72

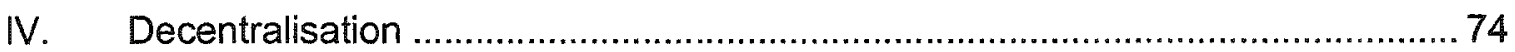

E. Empowering the European Commission to decide treaty infringements ............76

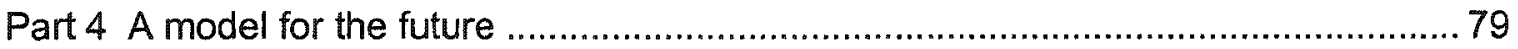

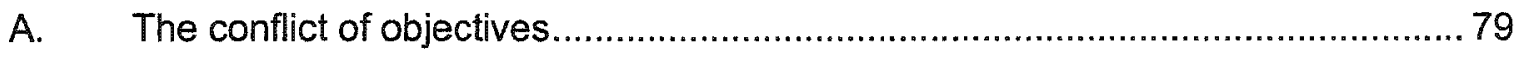

1. The rule of law and European integration ............................................... 80

II. The rule of law and the protection of individual rights ................................... 83

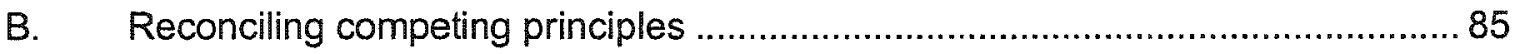

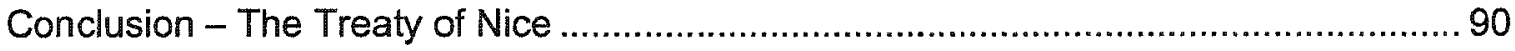




\begin{abstract}
The judicial system in what is now the European Union has been subject to only a few structural changes since the Court of Justice assumed jurisdiction over the European Economic Community and the European Atomic Energy Community. In a more significant development, the Court of Justice has shaped its own role and its relationship with the courts of the Member States. Today, the functioning of the resultant system is put at risk by an increasing case-load and duration of proceedings, but also by the impact of certain developments in the Community legal order and the intended enlargement of the European Union. Various mechanisms of reform, including those now framed by the Treaty of Nice, may remedy individual problems. But only the re-organisation of the courts according to their different essential tasks will lead to a principled structure for the future.
\end{abstract}

Le système judiciaire de la présente Union européenne fut soumis à seulement quelques changements structurels depuis que la Cour de justice a commencé à exercer les attributions de la juridiction sur la Communauté économique européenne et sur la Communauté européenne de l'énergie atomique. Le développement qui est plus significative, c'est que la Cour de justice a modelé, elle-même, son rôle et ses relations avec les cours des États membres. Aujourd'hui, le fonctionnement du système est menacé par une augmentation du nombre d'affaires et une prolongation des procédures, mais aussi à cause des conséquences des certains développements dans l'ordre juridique communautaire et du projet de l'élargissement de l'Union européenne. Divers mécanismes de réforme, y compris ceux qui sont maintenant proposés par le traité de Nice, résoudraient peut-être des problèmes individuels. Or, seule la réorganisation des cours conformément à leurs fonctions essentielles mènera à une structure pour l'avenir, qui sera réglée par des principes. 


\section{Bibliography and table of authorities}

\section{INTERNATIONAL AGREEMENTS}

Convention for the protection of human rights and fundamental freedoms, 4 November 1950 , [1969] E.T.S. No. 5

Convention on the grant of European patents, 5 October 1973, [1982] U.K.T.S. No. 16

\section{EUROPEAN COMMUNITIES AND EUROPEAN UNION: TREATIES, LEGISLATION AND OTHER DECISIONS AND AGREEMENTS}

Treaty establishing the European Coal and Steel Community, 18 April 1951, (1957) 261 U.N.T.S. 140

Protocol on the Statute of the Court of Justice, 18 April 1951, (1957) 261 U.N.T.S. 246

Treaty establishing the European Economic Community, 25 March 1957, (1958) 298 U.N.T.S. 3, now: Treaty establishing the European Community, [1997] O.J. C 340/173 (consolidated version)

Treaty establishing the European Atomic Energy Community, 25 March 1957, (1958) 298 U.N.T.S. 167

Convention relating to certain institutions common to the European Communities, 25 March 1957 , (1958) 298 U.N.T.S. 269

Protocol on the Statute of the Court of Justice of the European Economic Community, 17 April 1957, (1958) 298 U.N.T.S. 147

Protocol on the Statute of the Court of Justice of the European Atomic Energy Community, 17 April 1957, (1958) 298 U.N.T.S. 256

Regulation No 1 determining the languages to be used by the European Economic Community, 15 April 1958, in Dutch, French, German and Italian [1958] O.J. L 17/385

Decision of the Representatives of the Governments of the Member States on the provisional location of certain institutions and departments of the Communities, 8 April 1965, [1967] O.J. 152/67 (English special edition)

Convention on jurisdiction and the enforcement of judgments in civil and commercial matters, 27 September 1968, [1998] O.J. C 27/3 (consolidated version)

Protocol on the interpretation by the Court of Justice of the Convention of 27 September 1968 on jurisdiction and the enforcement of judgments in civil and commercial matters, 3 June 1971, [1998] O.J. C 27/28 (consolidated version)

Council Decision 74/584/EEC, Euratom, ECSC of 26 November 1974, [1974] O.J. L 318/20

Community Patent Convention, 15 December 1975 and 15 December 1989, [1989] O.J. L 401/10

Council Directive 76/207/EEC of 9 February 1976 on the implementation of the principle of equal treatment for men and women as regards access to employment, vocational training and promotion and working conditions, [1976] O.J. L 39/40 
Joint Declaration by the European Parliament, the Council and the Commission, 5 April 1977, [1977] O.J. C 103/1

Convention on the law applicable to contractual obligations, 19 June 1980, [1998] O.J. C 27/36 (consolidated version)

Single European Act, 17 February 1986 and 28 February 1986, [1987] O.J. L 169/1

Council Decision 88/591/ECSC, EEC, Euratom of 24 October 1988 establishing a Court of First Instance of the European Communities, [1988] O.J. L 319/1 and [1989] O.J. L 241/4 (corrigenda)

First Protocol on the interpretation by the Court of Justice of the European Communities of the Convention on the law applicable to contractual obligations, opened for signature in Rome on 19 June 1980, 19 December 1988, [1998] O.J. C 27/47 (consolidated version)

Second Protocol conferring on the Court of Justice of the European Communities certain powers to interpret the Convention on the law applicable to contractual obligations, opened for signature in Rome on 19 June 1980, 19 December 1988, [1998] O.J. C 27/52 (consolidated version)

Agreement relating to Community patents - Done at Luxembourg on 15 December 1989, [1989] O.J. L 401/1

Protocol on the settlement of litigation concerning the infringement and validity of Community patents, 15 December 1989, [1989] O.J. L 401/34

Council Directive 89/665/EEC of 21 December 1989 on the coordination of the laws, regulations and administrative provisions relating to the application of review procedures to the award of public supply and public works contracts, [1989] O.J. L 395/33

Rules of Procedure of the Court of First Instance of the European Communities of 2 May 1991, [1991] O.J. L 136/1 and [1991] O.J. L 317/34 (corrigenda)

Rules of Procedure of the Court of Justice of the European Communities of 19 June 1991, [1991] O.J. L 176/7 and [1992] O.J. L 383/1 (corrigenda)

Treaty on European Union, 7 February 1992, [1992] O.J. C 191/1 and [1997] O.J. C 340/145 (consolidated version)

Council Directive 92/13/EEC of 25 February 1992 on the coordination of the laws, regulations and administrative provisions relating to the application of Community rules on the procurement procedures of entities operating in the water, energy, transport and telecommunications sector, [1992] O.J. L 76/14

Decision taken by common agreement between the Representatives of the Governments of the Member States on the location of the seats of the institutions and of certain bodies and departments of the European Communities, 12 December 1992, reprinted European Communities, European Union - Selected Instruments taken from the Treaties (Luxembourg: Office for Official Publications of the European Communities, 1999) 795

Council Decision 93/350/Euratom, ECSC, EEC of 8 June 1993 amending Council Decision 88/591/ECSC, EEC, Euratom establishing a Court of First Instance of the European Communities, [1993] O.J. L 144/21

Council Regulation (EC) No 40/94 of 20 December 1993 on the Community trade mark, [1994] O.J. L 11/1 
Council Decision 94/149/ECSC, EC of 7 March 1994 amending Decision 93/350/Euratom, ECSC, EEC amending Decision 88/591/ECSC, EEC, Euratom establishing a Court of First Instance of the European Communities, [1994] O.J. L 66/29

Council Regulation (EC) No 2100/94 of 27 July 1994 on Community plant variety rights, [1994] O.J. L $227 / 1$

Council Decision 95/1/EC, Euratom, ECSC of 1 January 1995 adjusting the instruments concerning the accession of new Member States to the European Union, [1995] O.J. L 1/1

Council Regulation (EC) No 2506/95 of 25 October 1995 amending Regulation (EC) No 2100/94 on Community plant variety rights, [1995] O.J. L 258/3

Council Regulation (EC) No 384/96 of 22 December 1995 on protection against dumped imports from countries not members of the European Community, [1996] O.J. L 56/1

Treaty of Amsterdam amending the Treaty on European Union, the Treaties establishing the European Communities and certain related Acts, 2 October 1997, [1997] O.J. C 340/1

Protocol integrating the Schengen acquis into the framework of the European Union, 2 October 1997, [1997] O.J. C 340/93

Protocol on the location of the seats of the institutions and of certain bodies and departments of the European Communities and of Europol, 2 October 1997, [1997] O.J. C 340/112

Final Act of Amsterdam, 2 October 1997, [1997] O.J. C 340/115

Council Regulation (EC) No 2026/97 of 6 October 1997 on protection against subsidized imports from countries not members of the European Community, [1997] O.J. L 288/1

Council Act of 28 May 1998 drawing up, on the basis of Article K.3 of the Treaty on European Union, the Convention on jurisdiction and the recognition and enforcement of judgments in matrimonial matters, [1998] O.J. C 221/1

Council Act of 28 May 1998 drawing up, on the basis of Article K.3 of the Treaty on European Union, the Protocol on the interpretation by the Court of Justice of the European Communities of the Convention on jurisdiction and the recognition and enforcement of judgments in matrimonial matters, [1998] O.J. C 221/19

Amendments to the Rules of Procedure of the Court of First Instance of the European Communities to enable it to give decisions in cases when constituted by a single judge of 17 May 1999, [1999] O.J. L 135/92

Amendments to the Rules of Procedure of the Court of Justice of 16 May 2000, [2000] O.J. L $122 / 43$

Council Regulation (EC) No 1347/2000 of 29 May 2000 on jurisdiction and the recognition and enforcement of judgments in matrimonial matters and in matters of parental responsibility for children of both spouses, [2000] O.J. L 160/19

Charter of Fundamental Rights of the European Union solemnly proclaimed by the European Parliament, the Council and the European Commission, 7 December 2000, [2000] O.J. C 364/1

Council Regulation (EC) No 44/2001 of 22 December 2000 on jurisdiction and the recognition and enforcement of judgments in civil and commercial matters, [2001] O.J. L 12/1 
Treaty of Nice amending the Treaty on European Union, the Treaties establishing the European Communities and certain related Acts, 26 February 2001, [2001] O.J. C 80/1

Protocol on the Statute of the Court of Justice, 26 February 2001, [2001] 0.J. C 80/53

Final Act of Nice, 26 February 2001, [2001] O.J. C 80/70

Council Regulation (EC) No 6/2002 of 12 December 2001 on Community designs, [2002] O.J. L $3 / 1$

\section{OTHER LEGISLATION}

Canada: Supreme Court Act, formerly Supreme and Exchequer Courts Act, 1875, now R.S.C. 1985 c. S-26

Canada: Federal Court Act, 1970, now R.S.C. 1985 c. F-7

Canada: Tax Court of Canada Act, 1983, now R.S.C. 1985 c. T-2

Canada: Federal Court Rules, 1998, P.C. 1998-125, C. Gaz. 1998.II.424

United States of America: Constitution of the United States, 17 September 1787, reprinted [2001] U.S.C.S. Constitution

United States of America: Title 28 United States Code, 25 June 1948, [2001] 28 U.S.C.S.

United States of America: Rules of the Supreme Court of the United States, 26 July 1995, [2001] U.S.C.S. Court Rules

\section{JURISPRUDENCE}

Court of Justice: Judgment of 5 February 1963, Van Gend en Loos v Nederlandse Administratie der Belastingen, Case 26/62 [1963] E.C.R. 1

Court of Justice: Judgment of 18 February 1964, Crediet- en Handelsvereiniging Rotterdam and Suikerfabriek en Raffinaderij Puttershoek v Minister van Landbouw en Visserij, Cases 73 and 74/63 [1964] E.C.R. 1

Court of Justice: Judgment of 15 July 1964, Costa v ENEL, Case 6/64 [1964] E.C.R. 585

Court of Justice: Judgment of 1 December 1965, Schwarze v. Einfuhr- und Vorratsstelle für Getreide und Futtermittel, Case 16/65 [1965] E.C.R. 877

Court of Justice: Judgment of 12 November 1969, Stauder v Stadt Ulm, Case 29/69 [1969] E.C.R. 419

Court of Justice: Judgment of 6 October 1970, Grad v Finanzamt Traunstein, Case 9/70 [1970] E.C.R. 825

Court of Justice: Judgment of 17 December 1970, Internationale Handelsgesellschaft v Einfuhrund Vorratsstelle Getreide, Case 11/70 [1970] E.C.R. 1125

Court of Justice: Judgment of 14 May 1974, Nold v Commission, Case 4/73 [1974] E.C.R. 491

Court of Justice: Judgment of 4 December 1974, Van Duyn v Home Office, Case 41/74 [1974] E.C.R. 1337 
Court of Justice: Judgment of 28 October 1975, Rutili $\vee$ Minister for the Interior, Case 36/75 [1975] E.C.R. 1219

Court of Justice: Judgment of 22 January 1976, Russo v AIMA, Case 60/75 [1976] E.C.R. 45

Court of Justice: Judgment of 16 December 1976, Rewe Zentral $v$ Landwirtschaftskammer für das Saarland, Case 33/76 [1976] E.C.R. 1989

Court of Justice: Judgment of 16 December 1976, Comet v Produktschap voor Siergewassen, Case 45/76 [1976] E.C.R. 2043

Court of Justice: Judgment of 9 March 1978, Administrazione delle Finanze dello Stato v Simmenthal, Case 106/77 [1978] E.C.R. 629

Court of Justice: Judgment of 13 December 1979; Hauer v Land Rheinland-Pfalz, Case 44/79 [1979] E.C.R. 3727

Court of Justice: Judgment of 27 February 1980, Just $\vee$ Danish Ministry for Fiscal Affairs, Case 68/79 [1980] E.C.R. 501

Court of Justice: Judgment of 7 July 1981, Rewe Handelsgesellschaft Nord and Rewe Markt Steffen v Hauptzollamt Kiel, Case 158/80 [1981] E.C.R. 1805

Court of Justice: Judgment of 9 November 1983, Admministrazione delle Finanze dello Stato $v$ San Giorgio, Case 199/82 [1983] E.C.R. 3595

Court of Justice: Judgment of Judgment of 10 April 1984, Von Colson and Kamann v Land Nordrhein-Westfalen, Case 14/83 [1984] E.C.R. 1891

Court of Justice: Judgment of 23 April 1986, Les Verts v Parliament, Case 294/83 [1986] E.C.R. 1339

Court of Justice: Judgment of 15 May 1986, Johnston v Chief Constable of the Royal Ulster Constabulary, Case 222/84 [1986] E.C.R. 1651

Court of Justice: Judgment of 15 October 1987, UNECTEF v Heylens and Others, Case 222/86 [1987] E.C.R. 4097 at 4117

Court of Justice: Judgment of 22 October 1987, Foto Frost v Hauptzollamt Lübeck-Ost, Case 314/85 [1987] E.C.R. 4199

Court of Justice: Judgment of 22 February 1990, ECSC v Busseni, C-221/88 [1990] E.C.R. 1-495

Court of Justice: Judgment of 17 May 1990, $R$ v Secretary of State for Transport, ex parte Factortame and Others, C-213/89 [1990] E.C.R. I-2433

Court of Justice: Judgment of 22 May 1990, Parliament v Council, C-70/88 [1990] E.C.R. I-2041

Court of Justice: Judgment of 21 February 1991, Zuckerfabrik Süderditmmarschen v Hauptzollamt Itzehoe and Zuckerfabrik Soest v Hauptzollamt Paderborn, C-143/88 and 92/89 [1991] E.C.R. $1-415$

Court of Justice: Judgment of 21 July 1991, Emmot v Minister for Social Welfare and AttorneyGeneral, C-208/90 [1991] E.C.R. I-4269 
Court of Justice: Judgment of 19 November 1991, Francovich and Others v Italy, C-6 and 9/90 [1991] E.C.R. I-5357

Court of Justice: Opinion of 14 December 1991, Draft agreement between the Community, on the one hand, and the countries of the European Free Trade Association, on the other, relating to the creation of the European Economic Area, Opinion 1/91 [1991] E.C.R. I-6079

Court of Justice: Judgment of 27 October 1993, Steenhorst-Neerings v Bestuur van der Bedrijfsvereniging voor Detailhandel, Ambachten en Huisvrouwen, C-338/91 [1993] E.C.R. I-5475

Court of Justice: Judgment of 9 March 1994, Textilwerke Deggendorf v Germany, C-188/92 [1994] E.C.R. I-833

Court of Justice: Judgment of 14 July 1994, Faccini Dori v Recreb, C-91/92 [1994] E.C.R. I-3325

Court of Justice: Judgment of 6 December 1994, Johnson v Chief Adjudication Officer, C-410/92 [1994] E.C.R. I-5483

Court of Justice: Judgment of 9 November 1995, Atlanta Fruchhandelsgesellschaft and Others v Bundesamt für Ernährung und Forstwirtschaft, C-465/93 [1995] E.C.R. I-3761

Court of Justice: Judgment of 14 December 1995, Van Schijndel and Van Veen v Stichting Pensioenfonds voor Fysiotherapeuten, C-430 and 431/93 [1995] E.C.R. I-4705

Court of Justice: Judgment of 5 March 1996, Brasserie du Pêcheur $v$ Germany and $R . v$ Secretary of State for Transport, ex parte Factortame and Others, C-46 und 48/93 [1996] E.C.R. I-1029

Court of Justice: Opinion of 28 March 1996, Accession by the Community to the European Convention for the Protection of Human Rights and Fundamental Freedoms, Opinion 2/94 [1996] E.C.R. $1-1759$

Court of Justice: Judgment of 14 January 1997, Comateb and Others v Directeur Général des Douanes et Droits IndirectsJudgment, C-192 and 218/95 [1997] E.C.R. 165

Court of Justice: Judgment of 2 February 1997, Fantask and Others $v$ Industrieministeriet (Erhhervsministeriet), C-188/95 [1997] E.C.R. I-6783

Court of Justice: Judgment of 17 July 1997, Haahr Petroleum v Åbenrå Havn and Others, C90/94 [1997] E.C.R. I-4085

Court of Justice: Judgment of 17 July 1997, Texaco and Olieselkabet Danmark v Middelfart Havn and Others, C-114 and 115/95 [1997] E.C.R. 1-4263

Court of Justice: Judgment of 20 November 1997, Wiener SI v Hauptzollamt Emmerich, C-338/95 [1997] E.C.R. I-6495

Court of Justice: Judgment of 15 September 1998, EDIS v Ministero delle Finanze, C-231/96 [1998] E.C.R. I-4951

Court of Justice: Judgment of 17 December 1998, Baustahlgewerbe v Commission, C-185/95 P [1998] E.C.R. I-8417

European Commission of Human Rights: Decision of 10 July 1978, CFDT v European Communities and Others, Application No. 8030/77, 13 D.R. 231 
European Commission of Human Rights: Decision of 9 February 1990, M. \& Co. v Germany, Application No. 13258/87, 64 D.R. 138

European Court of Human Rights: Judgment of 26 February 1998, Pafitis and Others v Greece, Application No. 20323/92 ECHR Reports 1998-I 436

European Court of Human Rights: Judgment of 18 February 1999, Matthews v United Kingdom, Application No. 24833/94 ECHR Reports 1999-I 251

\section{DOCUMENTS OF THE EUROPEAN COMMUNITIES, THE EUROPEAN UNION AND THE MEMBER STATES}

Conference of the Representatives of the Governments of the Member States, Intergovernmental Conference on Institutional Reform (Report to the Feira European Council, 14 June 2000), Doc. No. CONFER $4750 / 00$

Conference of the Representatives of the Governments of the Member States, IGC 2000: Contribution from the French Delegation on Reform of the Judicial System of the European Union (Information Note, 27 March 2000), Doc. No. CONFER 4726/00

Court of First Instance, Contribution for the Purposes of the 1996 intergovernmental Conference (22 May 1995), reprinted in German [1995] Zeitschrift für Europäisches Gemeinschaftsrecht 320

Court of First Instance, Reflections on the Future Development of the Community Judicial System (Discussion Paper, 3 December 1990), reprinted (1991) 16 European Law Review 175

Court of Justice, Annual Report (extracts) - Statistics of Judicial Activity of the Court of Justice, Statistics of Judicial Activity of the Court of First Instance, 1998, 1999, 2000 <http://curia.eu.int/ en/pei/rapan.htm>

Court of Justice, Information Note on References by National Courts for Preliminary Rulings ( 9 December 1996) <http://curia.eu.int/en/txts/others/index.htm>

Court of Justice, Proposal for Amendment of Council Decision 88/591, with a view to extending the jurisdiction of the Court of First Instance (Proposal submitted to the Council, 27 October 1998) $<$ http://curia.eu.int/en/tsts/propositions/index.htm>

Court of Justice, Report on Certain Aspects of the Application of the Treaty on European Union (22 May 1995), reprinted in German [1995] Zeitschrift für Europäisches Gemeinschaftsrecht 316

Court of Justice \& Court of First Instance, Contribution by the Court of Justice and the Court of First Instance to the Intergovernmental Conference (Contribution to the Intergovernmental Conference on Institutional Reform, February 2000) <http://curia.eu.int/en/txt/intergov/cig.pdf>

Court of Justice \& Court of First Instance, The Future of the Judicial System of the European Union (Proposals and Reflections) (Discussion Paper, 10 May 1999) <http://curia.eu.int/en/txt/ intergov/ave.pdf>

Court of Justice \& Court of First Instance, Proposals Submitted by the Court of Justice and the Court of First Instance with Regard to the New Intellectual Property Cases (February 1999) <http://curia.eu.int/en/txts/propositions/index.htm>

European Commission, Promoting innovations through patents - The follow-up to the Green Paper on the Community patent and the patent system in Europe (Communication to the Council, the European Parliament and the Economic and Social Committee, 5 February 1999), COM (1999) 42 final 
European Commission, Proposal for a Council Regulation on the Community patent (1 August 2000), COM (2000) 412 final

European Commission, Reform of the Community Courts (Additional Commission Contribution to the Intergovernmental Conference on Institutional Reform, 1 March 2000) <http://europa.eu. int/comm/igc2000/offdoc/discussiondocs/cont04022000_en.pdf>

European Council, Presidency Conclusions - Nice European Council Meeting 7, 8 and 9 December 2000 , Doc. No. SN 400/00

European Council, Laeken Declaration on the future of the European Union, 14 and 15 December 2001, Doc. No. SN 300/01 ADD 1

Government of the United Kingdom, IGC 1996: Memorandum by the United Kingdom on the European Court of Justice (July 1996)

Government of the United Kingdom, A Partnership of Nations: The British Approach to the European Union Intergovernmental Conference 1996 (March 1996), Doc. No. Cm 3181

R. Schuman, Declaration of 9 May 1950, reprinted in English [1980] Bulletin of the European Communities No. 5,14

Working Party on the Future of the European Court of Justice, Report by the Working Party on the Future of the European Communities' Court System (Report to the Commission, January 2000) <http://europa.eu.int/comm/igc2000/offdoc/discussiondocs/index_en.htm>

\section{SECONDARY MATERIAL: MONOGRAPHS}

A. Arnull, The European Union and its Court of Justice (Oxford: Oxford University Press, 1999)

L. N. Brown \& T. Kennedy, L. N. Brown and F. G. Jacobs' The Court of Justice of the European Communities, $5^{\text {th }}$ ed. (London: Sweet \& Maxwell, 2000)

P. Craig \& G. de Búrca, EU Law, $2^{\text {nd }}$ ed. (Oxford: Oxford University Press, 1998)

R. H. Fallon, D. J. Meltzer \& D. L. Shapiro, Hart and Wechsler's The Federal Courts and the Federal System, $4^{\text {th }}$ ed. (Westbury: The Foundation Press, 1996)

T. C. Hartley, The Foundations of European Community Law, $4^{\text {th }}$ ed. (Oxford: Oxford University Press, 1998)

N. M. Hunnings, The European Courts (London: Cartermill, 1996)

P. W. Hogg, Constitutional Law of Canada, $4^{\text {th }}$ ed. (loose-leaf) (Scarborough: Carswell, 1997)

Members of the EC Section of the British Institute's Advisory Board chaired by The Rt. Hon. the Lord Slynn of Hadley, The Role and Future of the European Court of Justice (London: The British Institute of International and Comparative Law, 1996)

T. Millett, The Court of First Instance of the European Communities (London: Butterworths, 1990)

H. Rasmussen, On Law and Policy in the European Court of Justice (Dordrecht: Martinus Nijhoff, 1986) 
S. A. Scheingold, The Rule of Law in European Integration (New Haven: Yale University Press, 1965)

H. G. Schermers \& D. F. Waelbroeck, Judicial Protection in the European Communities, $5^{\text {th }}$ ed. (Deventer: Kluwer, 1992)

G. R. Stone et al., Constitutional Law, $4^{\text {th }}$ ed. (Gaithersburg: Aspen Law \& Business, 2001)

C. Wadlow, Enforcement of Intellectual Property in European and International Law (London: Sweet \& Maxwell, 1998)

\section{SECONDARY MATERIAL: ARTICLES}

K. Alter, "The European Union's Legal System and Domestic Policy: Spillover or Backlash?" (2000) 54 International Organization 489

K. Alter, "Explaining National Court Acceptance of European Court Jurisprudence: A Critical Evaluation of Theories of Legal Integration" in A.-M. Slaughter, A. Stone Sweet \& J. H. H. Weiler, eds., The European Court and National Courts - Doctrine and Jurisprudence (Oxford: Hart, 1998) 227

A. Arnull, "The Community Judicature and the 1996 IGC" (1995) 20 European Law Review 599

A. Arnull, "The European Court and Judicial Objectivity: A Reply to Professor Hartley" (1996) 112 The Law Quarterly Review 411

A. Arnull, "Judicial Architecture or Judicial Folly? The Challenge facing the European Union" (1999) 24 European Law Review 516

A. Arnull, "Private Applicants an the Action for Annulment under Article 173 of the EC Treaty" (1995) 32 Common Market Law Review 7

A. Arnull, "Refurbishing the Judicial Architecture of the European Community" (1994) 43 International and Comparative Law Quaterly 296

A. Arnull, "Rights and Remedies: Restraint or Activism?" in J. Lonbay \& A. Biondi, eds., Remedies for Breach of EC Law (Chichester: John Wiley \& Sons, 1997) 15

A. Arnull, "Underpinning the Community's Judicial Architecture" (1997) 22 European Law Review 1

P. Beaumont, "European Court of Justice and Jurisdiction and Enforcement of Judgments in Civil and Commercial Matters" (1997) 46 International and Comparative Law Quarterly 205

P. Beaumont, "European Court of Justice and Jurisdiction and Enforcement of Judgments in Civil and Commercial Matters" (1999) 48 International and Comparative Law Quarterly 223

K. Borgsmidt, "The Advocate General at the European Court of Justice: A Comparative Study" (1988) 13 European Law Review 106

R. D. Brewster, "Calling the Tune or Following the Lead: The European Court of Justice in European Policy Making" (1998) 13 Tulane European and Civil Law Forum 1

L. N. Brown, "National Protection of Community Rights: Reconciling Autonomy and Effectiveness" in J. Lonbay \& A. Biondi, eds., Remedies for Breach of EC Law (Chichester: John Wiley \& Sons, 1997) 67 
A. Bzdera, "L'Enjeu Politique de la Réforme Institutionelle de la Cour de Justice de la Communauté Européene" (1992) 356 Revue du Marché Commun et de l'Union Européene 240

A.-M. Burley \& W. Mattli, "Europe before the Court: A Political Theory of Legal Integration" (1993) 47 International Organization 41

M. Cappelletti, "Is the European Court of Justice 'Running Wild'?" (1987) 12 European Law Review 3

J. C. Cohen, "The European Preliminary Reference and U.S. Supreme Court Review of State Court Judgments: A Study in Comparative Judicial Federalism" (1996) 44 The American Journal of Comparative Law 421

P. Craig, "Once Upon a Time in the West: Direct Effect and the Federalization of EEC Law" (1992) 12 Oxford Journal of Legal Studies 453

P. Craig, "The Road to the 1996 Intergovernmental Conference: The Contribution of the European Court of Justice and the Court of First Instance" [1996] Public Law 13

R. Craufurd Smith, "Remedies for Breaches of EU Law in National Courts: Legal Variation and Selection" in P. Craig \& G. de Búrca, eds., The Evolution of EU Law (Oxford: Oxford University Press, 1999) 287

M. A. Dauses, "Empfiehlt es sich, das System des Rechtsschutzes und der Gerichtsbarkeit in der Europäischen Gemeinschaft weiterzuentwickeln?" (Report for the $60^{\text {th }}$ German Lawyers' Conference, 21 September 1994) in Ständige Deputation des Deutschen Juristentages, ed., Verhandlungen des Sechzigsten Deutschen Juristentags, vol. 1 (München: Beck, 1994) D 1

A. M. Donner, "The Constitutional Powers of the Court of Justice of the European Communities", (1974) 11 Common Market Law Review 127

P. R. Dubinsky, "The Essential Function of Federal Courts: The European Union and the United States Compared" (1994) 42 The American Journal of Comparative Law 295

O. Due, "The Court of First Instance" (1988) 8 Yearbook of European Law 1

O. Due, "The Impact of the Amsterdam Treaty upon the Court of Justice" (1999) 22 Fordham International Law Journal 48

D. Edward, "How the Court of Justice Works" (1995) 20 European Law Review 539

D. Edward, "What Kind of Law Does Europe Need? The Role of Law, Lawyers and Judges in Contemporary European Integration" (1998/1999) 5 Columbia Journal of European Law 1

U. Everling, "The Court of Justice as a Decisionmaking Authority" (1984) 82 Michigan Law Review 1294

U. Everiing, "Empfiehit es sich, das System des Rechtsschutzes und der Gerichtsbarkeit in der Europäischen Gemeinschaft weiterzuentwickeln?" (Comment for the $60^{\text {th }}$ German Lawyers' Conference, 21 September 1994) in Ständige Deputation des Deutschen Juristentages, ed., Verhandlungen des Sechzigsten Deutschen Juristentags, vol. 2, book 1 (München: Beck, 1994) N 9

U. Everling, "Justiz im Europa von Morgen" [1993] Deutsche Richterzeitung 5 
G. Garrett, R. D. Kelemen \& H. Schulz, "The European Court of Justice, National Governments, and Legal Integration in the European Union" (1998) 52 International Organization 149

W. Van Gerven, "Bridging the Gap Between Community and National Laws: Towards a Principle of Homogeneity in the Field of Legal Remedies?" (1995) 32 Common Market Law Review 679

W. van Gerven, "The Role and Structure of the European Judiciary now and in the Future", (1996) 21 European Law Review 211

C. Harlow, "A Common European Law of Remedies?" in C. Kilpatrick, T. Novitz \& P. Skidmore, eds., The Future of Remedies in Europe (Oxford: Hart, 2000) 69

C. Harlow, "Towards a Theory of Access for the European Court of Justice" (1992) 12 Yearbook of European Law 213

T. C. Hartley, "The European Court, Judicial Objectivity and the Constitution of the European Union" (1996) 112 The Law Quarterly Review 95

C. M. G. Himsworth, "Things Fall Apart: The Harmonisation of Community Judicial Procedural Protection Revisited" (1997) 22 European Law Review 291.

The Rt. Hon. The Lord Howe of Aberavon, "Euro-Justice: Yes or No?" (1996) 21 European Law Review 187

J.P. Jacqué \& J. H.H. Weiler, "On the road to European Union - A new Judicial Architecture: An Agenda for the Intergovernmental Conference" (1990) 27 Common Market Law Review 185

P. J. G. Kapteyn, "The Court of Justice of the European Communities after the Year 2000" in D. Curtin \& T. Heukels, eds., Institutional Dynamics of European Integration - Essays in Honour of Henry G. Schermers, vol. 2 (Dordrecht: Martinus Nijhoff, 1994) 135

T. Kennedy, "The Essential Minimum: The Establishment of the Court of First Instance" (1989) 14 European Law Review 7

C. Kilpatrick, "The Future of Remedies in Europe" in C. Kilpatrick, T. Novitz \& P. Skidmore, eds., The Future of Remedies in Europe (Oxford: Hart, 2000) 1

T. Koopmans, "The Future of the Court of Justice of the European Communities" (1991) 11 Yearbook of European Law 15

M. Lagrange, "La Cour de Justice des Communautés Européennes: Du Plan Schuman à I'Union Européenne" [1978] Revue Trimestrielle de Droit Européen 2

K. Lenaerts, "Constitutionalism and the Many Faces of Federalism" (1990) 38 The American Journal of Comparative Law 205

C. O. Lenz, "Reform des Europäischen Gerichtshofs im Blick auf die Erweiterung der Europäischen Union" (Forum Constitutionis Europae Lecture 4/00, Humboldt University, Berlin, 8 May 2000)<http://www.whi-berlin.de>

C. O. Lenz, "The Court of Justice of the European Communities" (1989) 14 European Law Review 127

V. Lipp, "Entwicklung und Zukunft der Europäischen Gerichtsbarkeit" [1997] Juristenzeitung 326 
G. F. Manchini, "The Making of a Constitution for Europe" (1989) 26 Common Market Law Review 595

G. F. Mancini \& D. T. Keeling, "From CILFIT to ERT: The Constitutional Challenge facing the European Court" (1991) 11 Yearbook of European Law 1

W. Mattli \& A.-M. Slaughter, "Revisiting the European Court of Justice" (1998) 52 International Organization 177

P. Mengozzi, "The Protection of Individual Rights and the Court of First Instance of the European Communities" (2000) 23 Fordham International Law Journal 707

J. Mischo, "Un Rôle nouveau pour la Cour de Justice?" (1990) 342 Revue du Marché Commun 681

N. A. E. M. Neuwahl, "Article 173 Paragraph 4 EC: Past, Present, and Possible Future" (1996) 21 European Law Review 17

J. Rinze, "The Role of the European Court of Justice as a Federal Constitutional Court" [1993] Public Law 426

G. C. Rodriguez Iglesias, "The EC Court of Justice and the Institutional Reform of the European Union" (Speech, April 2000) <http://curia.eu.int/en/txt/intergov/rod.pdf>

G. C. Rodríguez Iglesias, "Der Gerichtshof der Europäischen Gemeinschaften als Verfassungsgericht" [1992] Europarecht 225

D. W. J. Scorey, "A new Model for the Communities' Judicial Architecture in the new Union" (1996) 21 European Law Review 224

J. Sedemund, "Empfiehlt es sich, das System des Rechtsschutzes und der Gerichtsbarkeit in der Europäischen Gemeinschaft weiterzuentwickeln?" (Comment for the $60^{\text {th }}$ German Lawyers' Conference, 21 September 1994) in Ständige Deputation des Deutschen Juristentages, ed., Verhandlungen des Sechzigsten Deutschen Juristentags, vol. 2, book 1 (München: Beck, 1994) N 41

M. Shapiro, "The European Court of Justice" in P. Craig \& G. de Búrca, eds., The Evolution of EU Law (Oxford: Oxford University Press, 1999) 321

C. Stefanou and H. Xanthaki, "Are National Remedies the Only Way Forward? Widening the Scope of Article 215 (2) of the Treaty of Rome" in J. Lonbay \& A. Biondi, eds., Remedies for Breach of EC Law (Chichester: John Wiley \& Sons, 1997) 85

A. Stone Sweet \& T. L. Brunell, "Constructing a Supranational Constitution: Dispute Resolution and Governance in the European Community" (1998) 92 American Political Science Review 63

S. E. Strasser, "Evolution and Effort: Docket Control and Preliminary References in the European Court of Justice" (1996) 2 Columbia Journal of European Law 49

R. Streinz \& S. Leible, "Die Zukunft des Gerichtssystems der Europäischen Gemeinschaft Reflexionen über Reflexionspapiere" [2001] Europäisches Wirtschafts- \& Steuerrecht 1

E. Szyszcyak, "Making Europe More Relevant to its Citizens: Effective Judicial Process" (1996) 21 European Law Review 351

A. P. Tash, "Remedies for European Community Law Claims in Member State Courts: Toward a European Standard" (1993) 31 Columbia Journal of Transnational Law 377 
T. Tridimas, "The Court of Justice and Judicial Activism" (1996) 21 European Law Review 199

J. L. Da Cruz Vilaça, "La nouvelle Architecture Judiciaire Européene et la Conférence Intergouvernementale" (1996) 32 Cahiers de Droit Européen 3

J. L. Da Cruz Vilaça \& L. M. Pais Antunes, "The Court of First Instance of the European Communities: A Significant Step towards the Consolidation of the European Community as a Community Governed by the Rule of Law" (1990) 10 Yearbook of European Law 1

R. Voß, "Empfiehlt es sich, das System des Rechtsschutzes und der Gerichtsbarkeit in der Europäischen Gemeinschaft weiterzuentwickeln?" (Comment for the $60^{\text {th }}$ German Lawyers' Conference, 21 September 1994) in Ständige Deputation des Deutschen Juristentages, ed., Verhandlungen des Sechzigsten Deutschen Juristentags, vol. 2, book 1 (München: Beck, 1994) N 25

A. Ward, "The Limits of the Uniform Application of Community Law and Effective Judicial Review: A Look Post-Amsterdam" in C. Kilpatrick, T. Novitz \& P. Skidmore, eds., The Future of Remedies in Europe (Oxford: Hart, 2000) 213

J. H. H. Weiler, "The European Court, National Courts and References for Preliminary Rulings The Paradox of Success: A Revisionist View of Article 177 EEC" (EUI Working Paper 85/203) in EUI Working Papers (Badia Fiesolana: European University Institute, 1985) 


\title{
Acknowledgments
}

I would like to thank my supervisor, Professor Armand de Mestral, for helpful comments and suggestions. I also wish to thank Peter King and Menka Nagrani for their linguistic advice.

\begin{abstract}
Note
Attention needs to be drawn to the exact names of the courts established by European Union law. In particular, it is sometimes necessary to distinguish the Court of Justice of the European Communities as a judicial body from the Court of First Instance of the European Communities, commonly referred to as CFI. Where this is the case, I will speak of the former as 'Court of Justice as a court' according to the fact that the eventual amendments by the Treaty of Nice will introduce two separate jurisdictions. In any other case, the institution will be referred to in its entirety as 'Court of Justice of the European Communities' or 'Court of Justice' or simply 'Court'.
\end{abstract}




\section{Introduction}

The court system of the European Union is in need of reform. This thesis will explore why it is increasingly difficult for the Community judiciary to fulfil its function (Part 2), and from the discussion of various reform proposals a model for the judicial structure of the future will be inferred (Part 4). The recently concluded Treaty of Nice, ${ }^{1}$ despite its emphasis on the amendment of the provisions on the Court of Justice, has not rendered the need for such a model obsolete.

If the Treaty fails to be ratified, it will not be for disagreement over the requirement to make changes to the judicial system. Indeed, it will be shown (in Part 3) that in the past decade, both scholars and the Community institutions, including the Court of Justice itself, have made numerous contributions to a growing debate on the court system. During the intergovernmental conference in 2000 , there was an early understanding that the structure and operation of the Community courts needed to be innovated, and that further discussion should focus on the details, not the principle, of reform. ${ }^{2}$

Ratification of the Treaty of Nice, on the other hand, would not immediately bring about the necessary changes. The concluding part of the thesis will explain that in calling upon the Community institutions to implement reforms by way of separate decisions and amendments to the new Statute of the Court of Justice, ${ }^{3}$ the Treaty lays down only some of the aspects of the future of the judicial system in the European Union. A historical review of the development of courts applying European Union law will be given at the beginning (Part 1).

\footnotetext{
${ }^{1}$ Treaty of Nice amending the Treaty on European Union, the Treaties establishing the European Communities and certain related Acts, 26 February 2001, [2001] O.J. C 80/1 [hereinafter Treaty of Nice].

${ }^{2}$ See Conference of the Representatives of the Governments of the Member States, Intergovernmental Conference on Institutional Reform (Presidency Report to the Feira European Council, 14 June 2000), Doc. No. CONFER $4750 / 00$ at 39.

3 Protocol on the Statute of the Court of Justice, Nice, 26 February 2001, [2001] O.J. C 80/53 [hereinafter Statute of the Court of Justice (Nice)].
} 


\section{Part 1 History of the development of courts applying European Union law}

The foundations of what would later be called the 'judicial architecture"1 of the European Union were laid down with the establishment of the first of the Communities, the European Coal and Steel Community (ECSC). For a historical review of the institutional developments, it is proposed to first look at the Treaties in their original form including the Treaty establishing the ECSC ${ }^{2}$ although the latter will soon expire on 23 July 2002, 50 years after having entered into force. ${ }^{3}$

\section{A. A judicial system for the ECSC}

The ECSC Treaty created four institutions, a High Authority, a Common Assembly, a Special Council of Ministers and a Court of Justice, to regulate the envisaged 'pooling of coal and steel production'4 of the Member States. In the course of the negotiations leading to the signing of the Treaty, ${ }^{5}$ a system of institutional checks and balances had been brought about in which the Court of Justice was to ensure the rule of law in the interpretation and application of the present Treaty and of its implementing regulations. ${ }^{\prime}$ According to the common constitutional traditions of the Member States, the rule of law was thus entrusted to a permanent and independent judiciary. ${ }^{7}$

\footnotetext{
${ }^{1}$ The term was coined by Jean Paul Jacqué and Joseph H. H. Weiler, "On the Road to European Union - A new Judicial Architecture: an Agenda for the Intergovernmental Conference" (1990) 27 Common Market Law Review 185.

${ }^{2}$ Treaty establishing the European Coal and Steel Community signed in Paris on 18 April 1951, (1957) 261 U.N.T.S. 140 [hereinafter ECSC Treaty].

${ }^{3}$ Article 97 ECSC Treaty.

${ }^{4}$ These were the short-term objectives of the ECSC as proposed by Robert Schuman in the Declaration of 9 May 1950, reprinted in English [1980] Bulletin of the European Communities No. 5 at 14.

${ }_{5}^{5}$ For details with regard to the Court of Justice, see M. Lagrange, "La Cour de Justice des Communautés Européennes: Du Plan Schuman à l'Union Européenne" [1978] Revue Trimestrielle de Droit Européen 2; H. Rasmussen, On Law and Policy in the European Court of Justice (Dordrecht: Martinus Nijhoff, 1986) at 202 - 206.

Article 31 ECSC Treaty according to the translated version (from the French authentic text) offered in (1957) 261 U.N.T.S. 140 at 165; the newer official English translation reads slightly differently.

${ }^{7}$ See M. A. Dauses, "Empfiehlt es sich, das System des Rechtsschutzes und der Gerichtsbarkeit in der Europäischen Gemeinschaft weiterzuentwickeln?" (Report for the $60^{\text {th }}$ German Lawyers' Conference, 21 September 1994) in Ständige Deputation des Deutschen Juristentags, ed., Verhandlungen des Sechzigsten Deutschen Juristentags, vol. 1 (München: Beck 1994) D 1 at D 44.
} 
The main provisions on the Court of Justice conferred on it the power to annul acts of other Community organs. ${ }^{8}$ A request for annulment was to be made primarily by another institution or by one or several of the Member States, but under certain conditions undertakings and associations which could be addressed and sanctioned by the High Authority had also standing to take an appeal to the Court of Justice. ${ }^{9}$

The Court was also given the power to rule on a Member State's failure to fulfil its obligations under the Treaty, yet as part of general provisions at the end of the Treaty only..$^{10}$ Actions were to be brought either by another Member State as a dispute over the application of the Treaty, or in form of a request by the State allegedly infringing upon it to review a decision of the High Authority based on a finding of such failure. Consequently, the Member States have always been under some kind of scrutiny by the Court of Justice.

Ever since the ECSC was created, the institutional system of the Communities has not only comprised a court at the Community level but has also called for co-operation between that institution and the courts of the Member States. Thus, whereas the Court of Justice was given jurisdiction to assess damages against the ECSC related to a wrongful act or omission in the performance of its functions, ${ }^{11}$ it would be allowable before the domestic courts to involve the Community in any other litigation not pertaining to the application of treaty provisions or implementing regulations. ${ }^{12}$ Moreover, the Court was given exclusive jurisdiction to rule on the validity of acts of the High Authority or the Council even if contested before a tribunal in the Member States. ${ }^{13}$ This was the birth of a system of references for preliminary rulings that would later serve to establish an intensive dialogue between the national courts and the judiciary at the Community level.

The procedures and working methods of the Court were primarily influenced by a court structure found in French administrative law. ${ }^{14}$ This applies in particular to the office of advocate general, originally established by Article 10 of the Statute of the

\footnotetext{
${ }_{9}^{8}$ Articles 33,34 , and 38 ECSC Treaty.

${ }^{9}$ Article 33 para 2 and Article 36 ECSC Treaty; the term 'undertaking' is defined in Article 80 ECSC Treaty.

${ }_{11}^{10}$ See Articles 88 and 89 para 1 ECSC Treaty.

11 Article 40 para 1 and para 2 ECSC Treaty.

${ }^{12}$ See Article 40 para 3 ECSC Treaty. Also, see Article 6 ECSC Treaty conferring on the ECSC legal personality and the most extensive legal capacity under the laws of the Member States.

${ }_{13}$ Article 41 ECSC Treaty.

${ }^{14}$ See especially M. Lagrange, supra n. 5 at 5 .
} 
Court. ${ }^{15}$ The advocate general was modelled on the commissaire du gouvernement of the French Conseil d'État, but comparable offices exist also in the court systems of Belgium, Italy and the Netherlands. ${ }^{16}$ On the other hand, the obligation of domestic tribunals to ask the Court for a ruling on the validity of a legal act of the ECSC was inspired by similar exclusive jurisdictions of some of the Member States' constitutional courts concerning the validity of legislation, especially in Germany and Italy. ${ }^{17}$ However, the French influence on the tradition of the Court is still apparent in the continuing use of French as its single internal working language. ${ }^{18}$

\section{B. The emerging of a Court of Justice of the European Communities}

With the conclusion of the Treaties of Rome ${ }^{19}$ a legal system was established that, by and large, has endured until today: the European Economic Community (EEC) and the European Atomic Energy Community (EAEC) were added to the ECSC, each comprising new tasks for the judiciary. The various judicial functions pertaining to the respective Community jurisdictions were left separate, but a Convention also signed at Rome ${ }^{20}$ merged the court systems so as to create a single Court of Justice of the European Communities by drawing upon the resources of the former ECSC Court. ${ }^{21}$ Luxembourg, which had never been officially declared the seat of the Court but had served as its location in the founding years, became provisional seat of the new single Court. ${ }^{22}$ The loca-

${ }^{15}$ Protocol on the Statute of the Court of Justice signed in Rome on 18 April 1951, (1957) 261 U.N.T.S. 246 [hereinafter Statute (ECSC)].

${ }^{16}$ See K. Borgsmidt, "The Advocate General at the European Court of Justice: A Comparative Study" (1988) 13 European Law Review 106 at 106 - 107 and 113, and C. O. Lenz, "The Court of Justice of the European Communities" (1989) 14 European Law Review 127 at 130.

${ }^{17}$ See N. M. Hunnings, The European Courts (London: Cartermill, 1996) at $35-36$ and A. Arnull, The European Union and its Court of Justice (Oxford: Oxford University Press, 1999) at 49.

${ }^{18}$ D. Edward, "How the Court of Justice Works" (1995) 20 European Law Review 539 at 546 and C. O. Lenz, supra n. 16 at $131-132$.

19 Treaty establishing the European Economic Community signed in Rome on 25 March 1957, (1958) 298 U.N.T.S. 3 [hereinafter EEC Treaty]; Treaty establishing the European Atomic Energy Community (EURATOM) signed in Rome on 25 March 1957, (1958) 298 U.N.T.S. 167 [hereinafter EAEC Treaty].

${ }^{20}$ Convention relating to certain institutions common to the European Communities signed in Rome on 25 March 1957, (1958) 298 U.N.T.S. 269.

${ }^{21}$ For an account of the Court's personnel in the founding years, see S. A. Scheingold, The Rule of Law in European Integration (New Haven: Yale University Press, 1965) at 26 - 32.

${ }^{22}$ Article 3 of the Decision of the Representatives of the Governments of the Member States on the provisional location of certain institutions and departments of the Communities, done at Brussels on 8 April 1965, [1967] O.J. 152/67 (English special edition), reads: 
tion was declared definitive by common agreement between the governments of the Member States in 1992. ${ }^{23}$ This was confirmed by a Protocol on the location of the seats of the institutions and of certain bodies and departments of the European Communities and of Europol ${ }^{24}$ drawn up with the Treaty of Amsterdam in 1997. ${ }^{25}$ Both the Decision of 1992 and the Protocol state that they are without prejudice to the provisions concerning the seat of any future institutions or departments as contained in the Decision of 8 April 1965.

The jurisdiction of the Court of Justice has always been wider within the realm of the EAEC and EEC (now: European Community/EC) ${ }^{26}$ than according to the institutional framework of the ECSC. Under the EC and EAEC Treaties, the Member States are subject to more direct judicial scrutiny: it is only the Court rather than mainly the Commission/High Authority to rule that a Member State is persistently failing to comply with Community law. ${ }^{27}$ In both the EC Treaty and the EAEC Treaty, the provisions on Member State review are contained in the respective special sections on the Court, and they include the express rule that '[i]f the Court of Justice finds that a Member State has failed to fulfil an obligation under this Treaty, the State shall be required to take the necessary measures to comply with the judgment of the Court of Justice. ${ }^{28}$

The Court of Justice shall remain in Luxembourg.

There shall also be located in Luxembourg the judicial and quasi-judicial bodies, including those competent to apply the rules on competition, already existing or yet to be set up pursuant to the Treaties establishing the European Coal and Steel Community, the European Economic Community and the European Atomic Energy Community, or to conventions concluded within the framework of the Communities, whether between Member States or with third countries.

${ }^{23}$ Decision taken by common agreement between the Representatives of the Governments of the Member States on the location of the seats of the institutions and of certain bodies and departments of the European Communities, Edinburgh, 12 December 1992; the Decision is reprinted in European Union - Selected Instruments taken from the Treaties, Book I, vol. 1 (Luxembourg: Office for Official Publications of the European Communities, 1999) at 795.

${ }^{24}$ Protocol on the location of the seats of the institutions and of certain bodies and departments of the European Communities and of Europol, [1997] O.J. C 340/112.

${ }^{25}$ See Treaty of Amsterdam amending the Treaty on European Union, the Treaties establishing the European Communities and certain related Acts signed on 2 October 1997, [1997] O.J. C $340 / 1$ [hereinafter Treaty of Amsterdam].

${ }^{26}$ The Treaty on European Union, signed in Maastricht on 7 February 1992, [1992] O.J. C 191/1, has changed the name of the EEC to 'European Community'. The EEC Treaty was consequently termed Treaty establishing the European Community [hereinafter EC Treaty], and a consolidated version including the amendments and re-numbering brought about by the Treaty of Amsterdam has been published in [1997] O.J. C 340/173.

${ }_{27}$ Articles 226, 227 EC Treaty (ex Articles 169, 170 EC Treaty) and Articles 141, 142 EAEC Treaty.

${ }^{28}$ Article 228 (1) EC Treaty (ex Article 171 (1) EC Treaty) and Article 143 (1) EAEC Treaty. 
Also, according to the different decision-making powers and legislative procedures in the framework of the EC and EAEC, more institutions are subject to broad judicial review under Article 230 para 1 EC Treaty (ex Article 173 para 1 EC Treaty) and Article 146 para 1 EAEC Treaty. In contrast, the ECSC Treaty limits the Court's jurisdiction over an act of the Council or of the European Parliament/Assembly to the review of lack of competence and substantial procedural violations. ${ }^{29}$ When the Treaty on European Union ${ }^{30}$ established, for the first time, effective legislative powers of the European Parliament under the EC Treaty and constituted the European Central Bank by initiating the process of monetary union, Articles 173 to 176 EC Treaty (now Articles 230 to 233 EC Treaty) and Article 146 EAEC Treaty were revised so as to provide these bodies' standing to be sued and to sue in order to protect their prerogatives. As far as mere légitimation passive and légitimation active are concerned, the treaty amendments followed jurisprudence of the Court of Justice that had already established the Parliament's standing against the wording of former Article 173 EEC Treaty. ${ }^{31}$ However, amendments to the ECSC Treaty went only so far as to allow the Parliament's standing for the purpose of protecting its prerogatives, ${ }^{32}$ and they did not lift the limitations on judicial scrutiny of parliamentary acts according to Article 38 para 3 ECSC Treaty.

The empowerment of the Court of Justice under the EC and EAEC Treaties as opposed to the former Court of the ECSC is also shown by the role of individual litigants: any natural or legal person may bring actions against legal acts of the two Communities. ${ }^{33}$ This reflects that as a result of the increasing scope of competences introduced by the Treaties of Rome and the following treaty amendments, individuals of all sorts were to be addressed or at least directly and individually concerned by the Communities' administrative and legislative measures. ${ }^{34}$ The same can be said with respect to the

\footnotetext{
${ }^{29}$ Article 38 para 3 ECSC Treaty.

${ }^{30}$ Supra n. 26; the Treaty on European Union [hereinafter TEU] was amended and re-numbered by the Treaty of Amsterdam and a consolidated version has been republished in [1997] O.J. C $340 / 145$.

${ }^{31}$ Court of Justice, Judgment of 23 April 1986, Les Verts $\vee$ Parliament, Case 294/83 [1986] E.C.R. 1339, and Judgment of 22 May 1990, Parliament v Council, C-70/88 [1990] E.C.R. I-2041. For an account of the development of the Court's case law regarding the standing of the European Parliament, see A. Arnull, supra n. 17 at $34-38$.

32 See Article 33 para 4 ECSC as amended by Article H TEU (now Article 9 TEU). With the Treaty of Amsterdam, the Court of Auditors has now been given légitimation active after the same pattern under all three Treaties.

${ }^{33}$ Now, after insertion of new paragraphs by the TEU, Article 230 para 4 EC Treaty (ex Article 173 para 4 EC Treaty) and Article 146 para 4 EAEC Treaty.

${ }^{34}$ For further discussion of locus standi of individuals for the purpose of challenging Community acts, see Part 2 Section D Subsection II, below.
} 
standing of any individual and any legal person to claim the failure of either the EC or the EAEC to address to that person a particular decision. ${ }^{35}$ Under the ECSC Treaty, in contrast, proceedings against inactivity of the Commission/High Authority may only be instituted by another institution, the Member States, or by undertakings and certain associations. $^{36}$ Actions by any other individual party are not allowable.

Finally, the EC and EAEC Treaties have always provided for an express jurisdiction of the Court of Justice in disputes between the Community and its servants. ${ }^{37}$ However, with the exception of the preliminary rulings procedure, the provisions of the Treaties of Rome concerning other competences of the Court were largely taken from the ECSC Treaty. The single Court was thus given important uniform powers pervading the three of the Communities, such as the jurisdiction relating to the Communities' noncontractual liability or following an arbitration clause, or the competence to prescribe provisional measures in cases pending before it. The evolution of the provisions governing preliminary references from the courts of the Member States will be considered in the following section.

\section{Co-operation between the Court of Justice and the courts of the Member States}

As was the ECSC, both the EC and EAEC were given legal personality and the most extensive legal capacity accorded to legal persons under the laws of the Member States. ${ }^{38}$ The Communities could thus become party to legal proceedings not only before the Court of Justice, but also before domestic courts. ${ }^{39}$ As a consequence, the law governing the Communities as legal persons interacting with others was to be determined also by tribunals belonging to the court systems of the Member States. This would apply to disputes for which the Treaties did not establish jurisdiction at the Community level.

However, a very important strengthening of the relationship between the Court of Justice and the national courts had yet to emerge from the Treaties of Rome: the new

\footnotetext{
${ }^{35}$ Article 232 para 3 EC Treaty (ex Article 175 para 3 EC Treaty) and Article 148 para 3 EAEC Treaty.

${ }_{37}^{36}$ Article 35 ECSC Treaty.

${ }^{37}$ Article 236 EC Treaty (ex Article 179 EC Treaty) and Article 152 EAEC Treaty.

${ }^{38}$ Articles 281, 282 EC Treaty (ex Articles 210, 211 EC Treaty) and Articles 184, 185 EAEC Treaty.

${ }^{39}$ Article 240 EC Treaty (ex Article 183 EC Treaty), Article 155 EAEC Treaty, Article 40 para 3 ECSC Treaty.
} 
Communities incorporated a refined system of references for a preliminary ruling. It is worthwhile quoting here at length Article 234 EC Treaty (ex Article 177 EC Treaty), which includes an amendment made by the TEU in order to reflect the creation of the European Central Bank (ECB) but otherwise reads the same as the provisions of the original EEC Treaty:40

The Court of Justice shall have jurisdiction to give preliminary rulings concerning:

(a) the interpretation of this Treaty;

(b) the validity and interpretation of acts of the institutions of the Community and of the ECB;

(c) the interpretation of the statutes of bodies established by an act of the Council, where those statutes so provide.

Where such a question is raised before any court or tribunal of a Member State, that court or tribunal may, if it considers that a decision on the question is necessary to enable it to give judgment, request the Court of Justice to give a ruling thereon.

Where any such question is raised in a case pending before a court or tribunal of a Member State against whose decisions there is no judicial remedy under national law, that court or tribunal shall bring the matter before the Court of Justice.

The ECSC Treaty had hitherto not prescribed exactly how the interlocutory rulings of the Court of Justice must be instigated. Neither did Article 41 ECSC Treaty establish any reference procedure in order to obtain a ruling on the interpretation rather than on the validity of Community law. However, the case law of the Court of Justice has brought the respective provisions into line with each other. According to the Court, questions of interpretation may also be referred to it under the ECSC Treaty. ${ }^{41}$ Conversely, the Court has interpreted Article 234 EC Treaty so as to prohibit any domestic tribunal from considering a Community act invalid without asking for a preliminary ruling. ${ }^{42}$ Mandatory reference to the Court of Justice pertaining to the question of the validity of Community acts had before then only been addressed by the ECSC Treaty. Broadly speaking, with the Treaties of Rome it was thus established that any court of the Member States may request a ruling on the interpretation of all treaty law or on the validity and interpretation of any part of secondary Community law, and that it is required to do so when seriously

\footnotetext{
${ }^{40}$ Apart from the reference to the European Central Bank and another minor variation, the wording of Article 234 EC Treaty (ex Article 177 EC Treaty) and of Article 150 EAEC Treaty is identical.

${ }^{41}$ Court of Justice, Judgment of 22 February 1990, ECSC v Busseni, C-221/88 [1990] E.C.R. I495 , at 1-523 - 1-524. For a report on the development of the Court's interpretation concerning Article 41 ECSC since the conclusion of the Treaties of Rome, see H. G. Schermers \& D. F. Waelbroeck, Judicial Protection in the European Communities, $5^{\text {th }}$ ed. (Deventer: Kluwer, 1992) at $\S 684$.

42 Court of Justice, Judgment of 22 October 1987, Foto Frost $v$ Hauptzollamt Lübeck-Ost, Case 314/85 [1987] E.C.R. 4199.
} 
doubting the validity of a Community act, or in general if it is the court of last resort in the dispute brought before it. With respect to the referring court, however, the Court of Justice fulfils a complementary function, rather than being hierarchically superior. ${ }^{43}$ The relations are co-operative in nature. ${ }^{44}$

\section{The system of co-operation}

The system of co-operating courts is silently based on a principle the Treaties do not expressly mention. It is the principle of 'division of labour' according to which the Community legal order is applied both by courts at the institutional level of the Community and by national courts. It partly derives from the way Community law operates within the legal orders of the Member States. Apart from the Member States' obligations under the Treaties, secondary Community law can be either directly applicable or it may need to be incorporated into national law by legislative acts of the Member States. ${ }^{45}$ And it is now firmly established that Treaty provisions and Community legislation - even if not directly applicable according to the form of the legal act - may exert direct effect on individual legal relationships under certain conditions. ${ }^{46}$ The law in the Member States thus consists of legal rules enacted by institutions at the varied domestic levels as well as at the level of the Communities, and sometimes, law of domestic origin is penetrated by the requirements of directly effective provisions of the Community legal order.

This does not yet determine the system of courts for the interpretation and application of Community law, nor does it necessarily prescribe a particular structure. Federal states, confronted with the same phenomena, provide examples for parallel federal and provincial courts as in the United States or Canada, ${ }^{47}$ and for merged sys-

\footnotetext{
${ }^{43}$ D. Edward, supra n. 18 at 546, and H. G. Schermers \& D. F. Waelbroeck, supra n. 41 at $\S 689$.

${ }^{44}$ See e.g. A. Arnull, supra n. 17 at 51.

${ }^{45}$ See the distinction under Article 249 EC Treaty (ex Article 189 EC Treaty) and Article 161 EAEC Treaty between 'regulations' and 'directives', and the distinction between 'decisions' and 'recommendations' according to Article 14 ECSC Treaty respectively.

${ }^{46}$ See the case law of the Court of Justice following Judgment of 5 February 1963, Van Gend en Loos v Nederlandse Administratie der Belastingen, Case 26/62 [1963] E.C.R. 1 (provisions of the Treaties), Judgment of 6 October 1970, Grad v Finanzamt Traunstein, Case 9/70 [1970] E.C.R. 825 (decisions [EC] in conjunction with a directive addressed to the Member States), and Judgment of 4 December 1974, Van Duyn v Home Office, Case 41/74 [1974] E.C.R. 1337 (directives [EC]).

${ }^{47}$ In comparison with the United States where, according to the Constitution of the United States of 17 September 1787, reprinted [2001] U.S.C.S. Constitution, Article III Section 1, the federal jurisdiction is in principle 'vested in one supreme Court, and in such inferior Courts as the Congress may from time to time ordain and establish', the dualism of the Canadian court system is much less pronounced: provincial courts exercise jurisdiction in federal law matters except where the law provides otherwise, and the Supreme Court of Canada hears appeals in cases arising
} 
tems as in Germany where access to the federal level is preserved for a certain stage of appeal. Also, parallel structures can be encountered where separate sets of courts are established according to different branches of the law, while national supreme courts may or may not have special jurisdiction to rule on the interpretation and validity of higher order (respectively constitutional) law. Yet, the European Communities and its institutions, including the Court of Justice, are restricted to the tasks and competences as conferred upon them by the Treaties. ${ }^{48}$ The principle of limited empowerment means with respect to the Court that it has only limited jurisdiction in disputes involving private parties. It was noted above ${ }^{49}$ that individuals and legal persons have access to the Court of Justice in order to take action against Community measures and to claim reparation for damages caused by the Communities' institutions. But access does not extend further. A wide array of disputes involving rights and defences which are derived from, or informed by, Community law must thus be open for litigation before domestic courts. In fact, it is mainly the courts in the Member States that carry out the application of the Community legal order. ${ }^{50}$

National courts therefore share Community jurisdiction with the Court of Justice. They are 'Community courts' ${ }^{51}$ although the Treaties do not speak of them as such - that is the Treaties mention them hardly at all. In order to fulfil this function, the courts of the Member States are supported by way of the preliminary rulings procedure. The resultant structure does not precisely fit any of the court systems of federal states, and it needs to be worked in on the basis of mutual understanding and respect, the actual co-operation being entrusted to the courts. ${ }^{52}$ It follows from all of the above that the role of the domestic courts and their co-operation with the Court of Justice are necessarily part of the debate on the future of the Community judicial system.

under both provincial and federal laws; see P. W. Hogg, Constitutional Law of Canada, $4^{\text {th }}$ ed. (loose-leaf) (Scarborough: Carswell, 1997) at 7-2 - 7-4 and 8-7.

${ }^{48}$ Articles 5, 7 (1) EC Treaty (ex Articles 3b, 4 (1) EC Treaty) and Article 3 (1) EAEC Treaty; similar limits are prescribed by Article 5 para 1 ECSC Treaty.

${ }^{49}$ At $6-7$.

${ }^{50}$ See H. G. Schermers \& D. F. Waelbroeck, supra n. 41 at $\S 674$.

51 D. Edward, supra n. 18 at 546 . Recent German literature has stressed that the courts of the Member States constitute a part of a europäische Gerichtsbarkeit, a term that combines the meaning of jurisdiction and institutional system with respect to the application of Community law, see V. Lipp, "Entwicklung und Zukunft der Europäischen Gerichtsbarkeit" [1997] Juristenzeitung 326 at 326 n. 3, and M. A. Dauses, supra n. 7 at D $12-D 13$.

${ }^{52}$ See N. M. Hunnings, supra n. 17 at $35-36$. See also L. N. Brown \& T. Kennedy, eds., Brown and Jacobs' The Court of Justice of the European Communities, $5^{\text {th }}$ ed. (London: Sweet \& Maxwell, 2000) at 229 et seq. 


\section{Remedies and procedure in the national courts}

Ever since it is recognised that under certain conditions, the Community legal order is to be interpreted 'as producing direct effects and creating individual rights which national courts must protect', ${ }^{53}$ there has been a need for clarification of what the courts are actually required to do in order to provide that protection. Some requirements in view of particular remedies are contained in secondary Community law, but such legislative measures are rather exceptional. ${ }^{54}$ Therefore, the Court of Justice has been called upon, by way of references for a preliminary ruling, to set out procedural and remedial guidelines for the enforcement of Community rights. The Court has done so to such an extent that some commentators ${ }^{55}$ perceive it as overemphasizing 'judicial supra-nationalism' and consequently degrading domestic courts to the level of subordinate.

In an initial series of cases concerning remedies for breach of Community law, the Court of Justice underlined the autonomy of national courts and national proceedings, founded on the division of competence and the element of co-operation. ${ }^{56}$ Only two qualifications were made: the procedural conditions had not to be less favourable than those relating to comparable rights of domestic law (principle of 'non-discrimination' or 'equivalence'), and national rules would not be applicable, if they rendered the exercise of Community rights impossible or excessively difficult ('effectiveness' or 'practical

\footnotetext{
${ }^{53}$ Court of Justice, Judgment of 5 February 1963, Van Gend en Loos v Nederlandse Administratie der Belastingen, supra n. 46 at 13.

${ }^{54}$ See e.g. the remedies prescribed by Council Directive 89/665/EEC of 21 December 1989 on the coordination of the laws, regulations and administrative provisions relating to the application of review procedures to the award of public supply and public works contracts, [1989] O.J. L 395/33, and Council Directive 92/13/EEC of 25 February 1992 on the coordination of the laws, regulations and administrative provisions relating to the application of Community rules on the procurement procedures of entities operating in the water, energy, transport and telecommunications sector, [1992] O.J. L 76/14. For a discussion of the enforcement of Community intellectual property rights by courts of the Member States, see Section E Subsection II, below.

${ }^{55}$ See C. Kilpatrick, "The Future of Remedies in Europe" in C. Kilpatrick, T. Novitz \& P. Skidmore, eds., The Future of Remedies in Europe (Oxford: Hart, 2000) 1 at $10-12$, and C. Harlow, "A Common European Law of Remedies?" in C. Kilpatrick, T. Novitz \& P. Skidmore, ibid., 69 at 82. The implicit reproach of improper judicial activism is rejected, for example, by A. Arnull, "Rights and Remedies: Restraint or Activism?" in J. Lonbay \& A. Biondi, eds., Remedies for Breach of EC Law (Chichester: John Wiley \& Sons, 1997) 15, and M. Shapiro, "The European Court of Justice" in P. Craig \& G. de Búrca, eds., The Evolution of EU Law (Oxford: Oxford University Press, 1999) 321 at 335 and $339-340$.

${ }^{56}$ Court of Justice, Judgment of 16 December 1976, Rewe Zentralfinanz and Rewe Zentral v Landwirtschaftskammer für das Saarland, Case 33/76 [1976] E.C.R. 1989; Judgment of 16 December 1976, Comet v Produktschap voor Siergewassen, Case 45/76 [1976] E.C.R. 2043; Judgment of 27 February 1980, Just $\vee$ Danish Ministry for Fiscal Affairs, Case 68/79 [1980] E.C.R. 501; Judgment of 9 November 1983, Admministrazione delle Finanze dello Stato v San Giorgio, Case 199/82 [1983] E.C.R. 3595.
} 
impossibility' test). The same deference to the autonomy of judicial process was expressed by the Court when it held that the EC Treaty 'was not intended to create new remedies in the national courts to ensure the observance of Community law other than those already laid down by national law. ${ }^{.57}$ Thus, where it was appropriate to award an individual damages for the infringement of Community law by a Member State, the claim would have to be assessed in the context of the provisions of the domestic law regarding state liability. ${ }^{58}$ The principles of autonomy, equivalence and effectiveness continue sometimes to be invoked by the Court as limitations to its intervention in the conduct of judicial proceedings. ${ }^{59}$

However, the more remarkable of the Court's recent case law has intruded far into the domain of remedies and procedure. In a first move, the Court took the opportunity of the arrival of directives, which contained the general obligation of the Member States to introduce judicial procedures for the enforcement of rights provided for by these directives, ${ }^{60}$ in order to establish effective judicial protection as a principle of general nature and as an individual right. ${ }^{61}$ it held subsequently that for the sake of

${ }^{57}$ Court of Justice, Judgment of 7 July 1981, Rewe Handelsgesellschaft Nord and Rewe Markt Steffen v Hauptzollamt Kiel, Case 158/80 [1981] E.C.R. 1805 at 1838. However, the Court had previously ruled in Judgment of 9 March 1978, Administrazione delle Finanze dello Stato $\mathrm{v}$ Simmenthal, Case 106/77 [1978] E.C.R. 629 at 644, that the effective application of Community law may require existing remedies of the domestic law to be adapted.

${ }^{58}$ See Court of Justice, Judgment of 22 January 1976, Russo v AIMA, Case 60/75 [1976] E.C.R. 45 at 56.

59 See e.g. Court of Justice, Judgment of 27 October 1993, Steenhorst-Neerings $\vee$ Bestuur van der Bedrijfsvereniging voor Detailhandel, Ambachten en Huisvrouwen, C-338/91 [1993] E.C.R. I5475 at 1-5520; Judgment of 6 December 1994, Johnson v Chief Adjudication Officer, C-410/92 [1994] E.C.R. I-5483 at I-5509; Judgment of 14 December 1995, Van Schijndel and Van Veen v Stichting Pensioenfonds voor Fysiotherapeuten, C-430 and 431/93 [1995] E.C.R. I-4705 at I4737; Judgment of 14 January 1997, Comateb and Others v Directeur Général des Douanes et Droits Indirects, C-192 and 218/95 [1997] E.C.R. 165 at I-191; Judgment of 17 July 1997, Haahr Petroleum $\vee$ Åbenrå Havn and Others, C-90/94 [1997] E.C.R. I-4085 at I-4157; Judgment of 17 July 1997, Texaco and Olieselkabet Danmark v Middelfart Havn and Others, C-114 and 115/95 [1997] E.C.R. I-4263 at I-4285; Judgment of 15 September 1998, EDIS v Ministero delle Finanze, C-231/96 [1998] E.C.R. I-4951 at l-4986.

${ }^{60}$ See e.g. Council Directive 76/207/EEC of 9 February 1976 on the implementation of the principle of equal treatment for men and women as regards access to employment, vocational training and promotion and working conditions, [1976] O.J. L 39/40, Article 6. For a list of corresponding provisions in other measures on the equal treatment for men and women, see A. Arnull, supra $n$. 17 at 153 (annotation 55).

${ }^{61}$ See Court of Justice, Judgment of 10 April 1984, Von Colson and Kamann v Land NordrheinWestfalen, Case 14/83 [1984] E.C.R. 1891 at 1908, and Judgment of 15 May 1986, Johnston v Chief Constable of the Royal Ulster Constabulary, Case 222/84 [1986] E.C.R. 1651, which states at 1682:

The requirement of judicial control stipulated by [Article 6 of Directive 76/207] reflects a general principle of law which underlies the constitutional traditions common to the 
protecting Community rights effectively, national courts might be required to grant interim relief even where they lack this competence under national law. ${ }^{62}$ Rather than creating a new remedy, the ruling concerned the disapplication of a national obstacle to the grant of an available measure, ${ }^{63}$ but the Court went further soon. Referring to the principles of both effet utile and judicial protection of individuals, the Court prescribed for the domestic legal orders a remedy of state liability in damages for failure to implement particular rights of Community law. ${ }^{64}$ Thus, the Member States are to face a new kind of procedure in view of non-compliance with their obligations under the Treaties. The Court inserted this procedure into each Member State's own legal system. ${ }^{65}$ In another case, the Court struck down national procedural time-limits precluding claims for benefit that an individual had not been able to exercise for lack of proper transposition of a directive. $^{66}$ Later, however, the Court accepted limitations on the retroactive effect of similar

Member States. That principle is also laid down in Articles 6 and 13 of the European Convention for the Protection of Human Rights and Fundamental Freedoms of 4 November $1950 \ldots[T]$ he principles on which that Convention is based must be taken into account in Community law.

See also Court of Justice, Judgment of 15 October 1987, UNECTEF v Heylens and Others, Case 222/86 [1987] E.C.R. 4097 at 4117, a case relating to the freedom of movement for workers according to Article 48 EEC Treaty (now Article 39 EC Treaty).

${ }_{62}$ See Court of Justice, Judgment of 17 May $1990, R \vee$ Secretary of State for Transport, ex parte Factortame and Others, C-213/89 [1990] E.C.R. I-2433 at I-2474. As a follow-up, the Court set out guidelines for interim protection where the validity of Community measures is contested in proceedings before national courts; see Judgment of 21 February 1991, Zuckerfabrik Süderditmmarschen $\vee$ Hauptzollamt Itzehoe and Zuckerfabrik Soest $\vee$ Hauptzollamt Paderborn, C143/88 and 92/89 [1991] E.C.R. 1-415, and Judgment of 9 November 1995, Atlanta Fruchhandelsgesellschaft and Others $\vee$ Bundesamt für Ernährung und Forstwirtschaft, C-465/93 [1995] E.C.R. I-3761.

${ }_{63}$ See W. Van Gerven, "Bridging the Gap Between Community and National Laws: Towards a Principle of Homogeneity in the Field of Legal Remedies?" (1995) 32 Common Market Law Review 679 at 686 - 687, and A. Arnull, supra n. 17 at 166; contra A. P. Tash, "Remedies for European Community Law Claims in Member State Courts: Toward a European Standard" (1993) 31 Columbia Journal of Transnational Law 377 at $395-397$.

${ }_{64}$ See Court of Justice, Judgment of 19 November 1991, Francovich and Others v Italy, C-6 and 9/90 [1991] E.C.R. I-5357 at 5414, and Judgment of 14 July 1994, Faccini Doriv Recreb, C-91/92 [1994] E.C.R. I-3325 at I-3357. The Court has subsequently clarified that a remedy of this kind is not only available where a Member State fails to implement rights based on secondary Community law lacking direct effect as in the cases above, but that it also applies to the infringement of rights contained in directly effective provisions; see Judgment of 5 March 1996, Brasserie du Pêcheur v Germany and $R$. v Secretary of State for Transport, ex parte Factortame and Others, C-46 und 48/93 [1996] E.C.R. I-1029 at I-1143.

${ }_{65}$ An alternative remedy on the basis of Article 288 para 2 EC Treaty to be heard before the Court of Justice is proposed by $\mathrm{C}$. Stefanou and $\mathrm{H}$. Xanthaki, "Are National Remedies the Only Way Forward? Widening the Scope of Article 215 (2) of the Treaty of Rome" in J. Lonbay \& A. Biondi, supra n. 55 , at 85 et seq.

${ }^{66}$ Court of Justice, Judgment of 21 July 1991, Emmot $\vee$ Minister for Social Welfare and AttorneyGeneral, C-208/90 [1991] E.C.R. I-4269. 
claims against the state, and it repeatedly referred to the former ruling as necessitated by an exceptional case. ${ }^{67}$

To conclude one may say that the Court of Justice has indeed intervened strongly and that its case law has imposed new and original requirements upon the judicial process in the Member States. However, the Court seems not always consistent in its approach, often restricting itself for the sake of national procedural autonomy. The distinction between the supervision of procedural and substantive law is thus maintained. $^{68}$ Nevertheless, the judicial system continues to rely on the close co-operation between the domestic courts and the Community judiciary in every aspect of the law.

\section{Development of the Court of Justice under the Treaties}

Throughout the history of the Court of Justice, the number of judges and advocates general has related to the number of Member States, each accession to the Communities leading to an increase in personnel. There are currently eight advocates general and 15 judges $^{69}$ - one judge per Member State although the Treaties do not prescribe certain nationalities. ${ }^{70}$ The posts of advocates general are filled by the five most populous Member States and by rotation of the smaller ones. ${ }^{71}$

Apart from the adjustments concerning the personnel of the Court, only two amendments were made in the period between the conclusion of the Treaties of Rome and the Maastricht Treaty. Council Decision 74/584/EEC, Euratom, ECSC of 26 November $1974^{72}$ enabled the Court of Justice to form chambers in order to rule on pre-

67 See e.g. Judgment of 2 February 1997, Fantask and Others v Industrieministeriet (Erhervsministeriet), C-188/95 [1997] E.C.R. 1-6783 at I-6839, where the Court stated that 'the solution adopted in Emmott was justified by the particular circumstances of that case, in which the time-bar had the result of depriving the applicant of any opportunity whatever to rely on her right to equal treatment under a Community directive...'

${ }_{68}$ Greater harmonisation of national remedies and procedural law is called for by C. M. G. Himsworth, "Things Fall Apart: The Harmonisation of Community Judicial Procedural Protection Revisited" (1997) 22 European Law Review 291. See also E. Szyszcyak, "Making Europe More Relevant to its Citizens: Effective Judicial Process" (1996) 21 European Law Review 351.

${ }^{69}$ See Article 221 para 1 and Article 222 para 1 EC Treaty (ex Article 165 para 1 and ex Article 166 para 1 EC Treaty) and the corresponding provisions of the EAEC and ECSC Treaties.

70 The Court of First Instance currently also consists of one 'member' from each Member State all of whom sit as judges and may be called upon exceptionally to perform the tasks of an advocate general, see Council Decision 88/591/ECSC, EEC, Euratom of 24 October 1988 establishing a Court of First Instance of the European Communities, infra n. 76, Article 2 (1) and (3), as amended by the Act of Accession of 24 June 1994 in the version set out in Article 10 of Council Decision 95/1/EC, Euratom, ECSC of 1 January 1995 adjusting the instruments concerning the accession of new Member States to the European Union, [1995] O.J. L 1/1.

71 See L. N. Brown \& T. Kennedy, supra n. 52 at $71-72$.

${ }^{72}$ Council Decision 74/584/EEC, Euratom, ECSC of 26 November 1974, [1974] O.J. L 318/20. 
liminary references, a possibility that had been prohibited by reference to this procedure. ${ }^{73}$ And upon entry into force of the Single European $\mathrm{Act}^{74}$ in 1987, the Council became empowered to attach to the Court a Court of First Instance (CFI) by way of subsequent decision. ${ }^{75}$ New Article 168a EEC Treaty and the corresponding provisions inserted into the EAEC and ECSC Treaties predetermined the new judicial body's limited jurisdiction by excluding from it preliminary references and two categories of cases coinciding with those preserved from assignment to a chamber of the Court of Justice as a court: actions brought by Member States and those brought by Community institutions. Council Decision 88/591/ECSC, EEC, Euratom of 24 October $1988^{76}$ then established the $\mathrm{CFI}$ and introduced provisions concerning its organisation and procedure into the three Protocols on the Statutes of the Court of Justice. The Decision transferred to the $\mathrm{CFI}$ the jurisdiction in a narrow range of cases, which were considered to

frequently require an examination of complex facts, that is to say actions or proceedings brought by servants of the Communities and also, in so far as the ECSC Treaty is concerned, by undertakings and associations in matters concerning levies, production, prices, restrictive agreements, decisions or practices and concentrations, and so far as the EEC Treaty is concerned, by natural or legal persons in competitions matters... ${ }^{77}$

According to the provisions of the Treaties, an appeal on points of law only would lie from any decision of the CFI to the Court of Justice as the other court. As implied by the wording of the Treaties and the fact that the CFI was to be constituted by way of Council decision, only the inner-institutional was concerned, the CFI being subordinate to another judicial body and, albeit consisting of an independent judiciary, by no means an autonomous Community institution. ${ }^{78}$

Changes to the scope of procedures open for transfer to the jurisdiction of the CFI were introduced by the TEU in late 1993 (entry into force) along with further

\footnotetext{
${ }^{73}$ See Article 164 para 3 of the original EEC Treaty and Article 137 para 3 of the original EAEC Treaty. Identical restrictions were contained in Article 32 ECSC Treaty as revised by the Convention of 25 March 1957, supra n. 20.

${ }^{74}$ Single European Act signed at Luxembourg on 17 February 1986 and at The Hague on 28 February 1986, [1987] O.J. L 169/1.

${ }^{75}$ For details on the background to, and the measures for, the establishment of the Court of First Instance, see especially T. Kennedy, "The Essential Minimum: The Establishment of the Court of First Instance" (1989) 14 European Law Review 7.

${ }^{76}$ Council Decision 88/591/ECSC, EEC, Euratom of 24 October 1988 establishing a Court of First Instance of the European Communities, [1988] O.J. L 319/1 and [1989] O.J. L 241/4 (corrigenda). ${ }^{77} 16^{\text {th }}$ Recital of the Decision.

${ }^{78}$ See T. Millett, The Court of First Instance of the European Communities (London: Butterworths, 1990) at 7, and J. L. da Cruz Vilaça \& L. M. Pais Antunes, "The Court of First Instance of the European Communities: A Significant Step towards the Consolidation of the European Community as a Community Governed by the Rule of Law" (1990) 10 Yearbook of European Law 1 at 18 -19 .
} 
amendments to the possibility of assigning cases to a chamber. According to revised Article 165 para 2 EC Treaty (now Article 221 para 2 EC Treaty) and the corresponding amendments to the other Treaties, chambers of the Court of Justice as a court may now be assigned to hear cases of all sorts. However, a Member State or a Community institution that is a party to the particular proceeding may request that the Court sit in plenary session. ${ }^{79}$ Cases before the CFI, on the contrary, have always been heard by chambers ${ }^{80}$ - and only since the Rules of Procedure of the CFI entered into force in 1991, a chamber as well as the President of the CFI may, in special cases or under extraordinary circumstances, refer a proceeding to the CFI sitting in plenary session. ${ }^{81}$ As to the competences of the CFI, Article 168a EC Treaty (now Article 225 EC Treaty) and the corresponding provisions of the EAEC and ECSC Treaties were revised by the TEU in order to allow any category of procedure other than preliminary references to be transferred to it. However, two Council Decisions of 1993 and $1994^{82}$ extended the jurisdiction of the CFI only so far as to reach the maximum scope to which it had been allowed under the original provisions. Today, the CFI has jurisdiction to hear and determine at first instance no more than the range of cases it had been given by 1994: actions brought by Community personnel against their employer; direct actions by natural or legal persons against a Community institution; and damages claims by natural or legal persons according to Article 288 EC Treaty (ex Article 215 EC Treaty), Article 188 EAEC Treaty and Article 40 ECSC Treaty.

Besides the aforementioned amendments and the treaty revisions pertaining to the standing of the European Parliament and the $\mathrm{ECB},{ }^{83}$ the Maastricht Treaty brought a substantial change to the powers of the Court of Justice as regards persistent infringements of the Treaties by a Member State. The Court may now impose financial

\footnotetext{
${ }^{79}$ Article 165 para 3 EC Treaty (now Article 221 para 3 EC Treaty), Article 137 para 3 EAEC Treaty, Article 32 para 3 ECSC Treaty.

${ }^{80}$ See Council Decision 88/591/ECSC, EEC, Euratom, supra n. 76, Article 2 (4).

${ }^{81}$ See Rules of Procedure of the Court of First Instance of the European Communities of 2 May 1991, [1991] O.J. L 136/1 and [1991] O.J. L 317/34 (corrigenda) [hereinafter Rules of Procedure (CFI)], Articles 13 (1) and 11 (1) para 1 and the references made by Article 11 (1) para 2.

${ }^{82}$ Council Decision 93/350/Euratom, ECSC, EEC of 8 June 1993 amending Council Decision 88/591/ECSC, EEC, Euratom establishing a Court of First Instance of the European Communities, [1993] O.J. L 144/21, and Council Decision 94/149/ECSC, EC of 7 March 1994 amending Decision 93/350/Euratom, ECSC, EEC amending Decision 88/591/ECSC, EEC, Euratom establishing a Court of First Instance of the European Communities, [1994] O.J. L 66/29.

${ }^{83}$ See Section $B$, above.
} 
sanctions, if Member States do not comply with a judgment that holds them failing to fulfil an obligation under the Treaties. ${ }^{84}$

In contrast, the Court of Justice was hardly affected by the introduction of a European Union institutional structure being superimposed on the three Communities (the 'first pillar') and comprising a system of intergovernmental co-operation and common action within the 'second' and 'third pillars', the foreign and security policy and justice and home affairs. According to Article L TEU (now, after amendment, Article 46 TEU), the intergovernmental pillars were excluded from the jurisdiction of the Court. The same applied to the respect for fundamental rights, which was laid down as a European Union principle in Article F TEU (now Article 6 TEU). As a mere exception, Article K.3 (2) (c) of the original TEU allowed the Member States to confer jurisdiction on the Court concerning the interpretation and application of conventions concluded within the framework of co-operation in justice and home affairs. These limitations on the powers of the Court have recently been loosened by the Treaty of Amsterdam, which stipulates the current state of European Union treaty law. ${ }^{85}$

It was expected that the Treaty of Amsterdam would make changes to the judicial institutions in the European Union, as the intergovernmental conference in 1996/1997 was proceeding at a time when debate on the future of the court system had been pushed ahead by both scholars and some of the Member States and Community institutions. ${ }^{86}$ The actual amendments, however, were almost completely limited to the provisions on the jurisdiction of the Court of Justice relating to various parts of the former area of justice and home affairs and to other matters of the TEU.

By transferring certain policies from the European Union to the EC, the Treaty of Amsterdam established new Community competences with respect to visas, asylum, immigration and other aspects of the free movement of persons, in particular in the field of judicial co-operation between the Member States in civil matters. ${ }^{87}$ Instead of submitting this area to the jurisdiction of the Court of Justice as it stands in general, two limitations have been given effect. First, only domestic courts of last resort are allowed -

\footnotetext{
${ }^{84}$ Article 228 (2) EC Treaty (ex Article 171 EC Treaty) and Article 143 (2) EAEC Treaty. The ECSC Treaty has always provided for sanctions by the Commission/High Authority with the approval of a qualified majority of votes in the Council, the sanctions being subject to full judicial review by the Court of Justice, see Article 88 ECSC Treaty.

${ }^{85}$ The Treaty of Amsterdam, supra n. 25, entered into force on 1 May 1999.

${ }^{86}$ See e.g. P. Craig \& G. de Búrca, EU Law, $2^{\text {nd }}$ ed. (Oxford: Oxford University Press, 1998) at 85, and O. Due, "The Impact of the Amsterdam Treaty upon the Court of Justice" (1999) 22 Fordham international Law Journal 48 at 51.

${ }^{87}$ See Articles 61 - 67 EC Treaty.
} 
and required - to request a preliminary ruling. ${ }^{88}$ The Court of Justice, secondly, is prohibited from reviewing Council acts in connection with the absence of controls on persons crossing internal borders, if the measures taken are related to the maintenance of law and order or to the safeguarding of internal security. ${ }^{89}$ However, new Article 68 (3) EC Treaty has introduced a procedure previously unknown to the Treaties: the Council, the Commission and the Member States may ask the Court a Justice for a ruling on the interpretation of the provisions here concerned, or on the interpretation of Community acts based thereon. It is a variation on the French pourvoi dans l'intérêt de la $10 i,{ }^{90}$ proceeding without participation of the parties to any case that might have given rise to the request and bearing no effect on any previous court decisions.

As to the remaining part of the European Union's third pillar, now consisting of provisions on police and judicial co-operation in criminal matters, the competences of the Court of Justice have been extended by a set of complex rules. A Member State may declare acceptance of the Court's jurisdiction to rule on questions referred to it by a court of that State in a procedure resembling preliminary references under Article 234 EC Treaty. ${ }^{91}$ It is left to the Member State to decide whether references are to be made by any court or by the courts of last resort only, ${ }^{92}$ and it may prescribe as a matter of national law that tribunals of the latter type have an obligation to refer. ${ }^{93}$ Preliminary rulings may be given on the interpretation and in some cases on the interpretation and validity of certain measures, but they cannot be requested for the interpretation of treaty provisions. Article 35 (5) TEU furthermore excludes the Court from ruling on the validity and proportionality of measures concerning the maintenance of law and order and the safeguarding of internal security, in this case when carried out by organs of the Member States.

Unconditional jurisdiction was conferred on the Court in actions brought by a Member State or the European Commission in order to challenge framework decisions or decisions with respect to criminal matters. ${ }^{94}$ Moreover, the Court may now rule on disputes between Member States concerning the interpretation or application of the

\footnotetext{
${ }^{88}$ Article 68 (1) EC Treaty.

${ }^{89}$ Article 68 (2) EC Treaty.

${ }^{90}$ See K. Borgsmidt, supra n. 16 at 113.

${ }^{91}$ See Article 35 (1) and (2) Treaty.

${ }^{92}$ Article 35 (3) TEU.

${ }^{93}$ See Declaration (No. 10) on Article 35 of the Treaty on European Union adopted by the Conference of the Representatives of the Governments of the Member States, Final Act of Amsterdam done on 2 October 1997, [1997] O.J. C 340/115 at 133.

${ }^{94}$ See Article 35 (6) TEU.
} 
widest range of acts within the third pillar, yet only following the failure of a political settlement by the Council ${ }^{95}$ - and it has been given jurisdiction in disputes between Member States and the Commission with regard to the interpretation and application of conventions. $^{96}$

The TEU was furthermore amended in order to allow the Court of Justice to review the action of the Community institutions with regard to the principle of fundamental rights insofar as the Treaties establish the jurisdiction of the Court. ${ }^{97}$ Finally, the new possibility of closer co-operation in view of particular policies ${ }^{98}$ has been linked to the submission to the Court's jurisdiction in correspondence with the field of law to which the policies would belong under the Treaties (EC or European Union). ${ }^{99}$

It follows that according to the changes brought about by the Treaty of Amsterdam, the Court of Justice now assumes some role on the level of the European Union. However, one may say that the actual function is minor, ${ }^{100}$ for the Court's competences are limited by complex provisions and the submission to its jurisdiction remains partly voluntary. Individuals, as is criticised by some authors, ${ }^{101}$ still lack a sufficient guarantee of judicial protection against activities under the provisions of the third pillar. ${ }^{102}$ This further reduces the significance of the Court outside the realm of the three Communities. Given the intergovernmental nature of the policies within the second and the third pillar, it comes as no surprise, however, that the existence of the European Union institutional structure does not have the same impact on the Community judiciary as it does for the construction of a closer political union between the Member States.

\footnotetext{
${ }^{95}$ Article 35 (7) TEU

${ }^{96}$ Ibid.

${ }^{97}$ See Article 46 (d) TEU.

${ }^{98}$ See Articles 43 - 45 TEU

${ }^{99}$ Article 11 (4) EC Treaty, and Article 40 (4) para 1 TEU with Article 35 TEU respectively. However, the actual establishment of closer co-operation as well as any subsequent accession are subject to judicial review according to the competences of the Court under the EC Treaty, see Article 40 (4) para 2.

${ }^{100}$ See O. Due, supra n. 86 at 71.

${ }^{101}$ A. Arnull, supra n. 17 at $71-73$; O. Due, supra n. 86 at 66 . For further analysis, see A. Ward, "The Limits of the Uniform Application of Community Law and Effective Judicial Review: A Look Post-Amsterdam" in C. Kilpatrick, T. Novitz \& P. Skidmore, supra n. 55 at 213 et seq.

${ }_{102}$ As a consequence, the European Court of Human Rights might decide to exercise jurisdiction in applications calling into question the respect for fundamental rights as concerns a measure by the European Union: the Court has recently held the Member States responsible for the violation of human rights by an act which belongs to the Community legal order (revision of the EEC Treaty by the Maastricht Treaty) but cannot be challenged before the Court of Justice; see Judgment of 18 February 1999, Matthews v United Kingdom, Application No. 24833/94, ECHR Reports 1999-1 251 at 266. For further discussion of the protection of fundamental rights in Community law, see Part 2 Section D Subsection II, below.
} 


\section{E. Secondary Community law and conventions concluded between the Member States}

The court system of the European Union has been shaped also by constitutional provisions contained in Community legislation and in Member State agreements complementing the Treaties. A selection of these provisions is of interest for the present purpose and will be examined briefly.

\section{Judicial co-operation}

The Member States have drawn up a number of conventions in order to co-operate on a state-to-state basis in areas not (then) covered by the Treaties. Although concluded as international agreements, they are closely linked to the Community legal order, ${ }^{103}$ and some are considered a part of the acquis communautaire to be extended in full with any accession of new Member States. ${ }^{104}$ Today, conventions in the field of police and judicial co-operation in criminal matters are to be established and implemented under the auspices of the European Union. ${ }^{105}$

Where the Member States have desired the Court of Justice to ensure uniform interpretation of particular conventions, they concluded separate protocols providing for its jurisdiction. Powers under the Protocol on the interpretation by the Court of Justice of the Convention of 27 September 1968 on jurisdiction and the enforcement of judgments in civil and commercial matters, ${ }^{106}$ for instance, have served the Court for establishing a firm body of case law concerning the so-called 'Brussels Convention'. ${ }^{107}$ When applying the Brussels Convention, the highest courts of the Member States and those acting as appeal courts are empowered to request preliminary rulings on questions of interpretation raised in a case pending before them. ${ }^{108}$ The same would have applied with regard to the Convention on jurisdiction and the recognition and enforcement of judgments in

\footnotetext{
${ }^{103}$ Some conventions, for example, have been drawn up following the suggestion for negotiations between Member States pursuant to Article 293 EC Treaty (ex Article 220 EC Treaty).

${ }^{104}$ See e.g. Protocol integrating the Schengen acquis into the framework of the European Union, Amsterdam, 2 October 1997, [1997] O.J. C 340/93.

${ }^{105}$ See Article 34 (2) (d) TEU. For a discussion of the jurisdiction of the Court of Justice in disputes concerning acts establishing or implementing such conventions and in disputes over the interpretation or application, see text accompanying notes 95 and 96 , above.

${ }^{106}$ Protocol on the interpretation by the Court of Justice of the Convention of 27 September 1968 on jurisdiction and the enforcement of judgments in civil and commercial matters signed in Luxembourg on 3 June 1971, [1998] O.J. C 27/28 (consolidated version).

${ }_{107}$ Convention on jurisdiction and the enforcement of judgments in civil and commercial matters, done at Brussels on 27 September 1968, [1998] O.J. C 27/3 (consolidated version).

${ }^{108}$ See Articles 2 and 3 of the Protocol.
} 
matrimonial matters ${ }^{109}$ as drawn up pursuant to the original Article K.3 (2) (c) TEU, if the agreements had been ratified by the Member States before becoming a substantial part of a Council Regulation based on new Article 61 EC Treaty. ${ }^{110}$ Now, preliminary references in this area are governed by the provisions of the EC Treaty instead of a Protocol drafted with the Convention. ${ }^{111}$ With effect of 1 March 2002, the Brussels Convention, too, has been incorporated into secondary Community law. ${ }^{112}$ As was noted above, ${ }^{113}$ Article 68 EC Treaty modifies the Court's jurisdiction with respect to Community legislation on judicial co-operation in civil matters.

As another example, the Convention on the law applicable to contractual obligations opened for signature in Rome on 19 June $1980^{114}$ has been complemented by two Protocols conferring on the Court of Justice the jurisdiction to give preliminary rulings on questions of interpretation. Here, again, requests are to be made by the Member States' highest courts or any tribunal acting in appellate capacity. ${ }^{115}$ Although the 'Rome Convention' is completely in force, the Second Protocol has not yet been ratified by every Member State as required for the jurisdiction of the Court to come into effect. ${ }^{116}$

The aforementioned instruments also comprise procedures for a pourvoi dans l'intérêt de la loi of the type recently included in the EC Treaty: ${ }^{117}$ the Member States, through their competent authorities, as well as the procurators general at the national

\footnotetext{
${ }^{109}$ See Council Act of 28 May 1998 drawing up, on the basis of Article K.3 of the Treaty on European Union, the Convention on jurisdiction and the recognition and enforcement of judgments in matrimonial matters, [1998] O.J. C 221/1.

${ }^{110}$ Council Regulation (EC) No $1347 / 2000$ of 29 May 2000 on jurisdiction and the recognition and enforcement of judgments in matrimonial matters and in matters of parental responsibility for children of both spouses, [2000] O.J. L 160/19. The Regulation entered into force on 1 March 2001.

111 See Council Act of 28 May 1998 drawing up, on the basis of Article K.3 of the Treaty on European Union, the Protocol on the interpretation by the Court of Justice of the European Communities of the Convention on jurisdiction and the recognition and enforcement of judgments in matrimonial matters, [1998] O.J. C 221/19, Articles 2 - 4.

112 See Council Regulation (EC) No 44/2001 of 22 December 2000 on jurisdiction and the recognition and enforcement of judgments in civil and commercial matters, [2001] O.J. L 12/1.

${ }^{113}$ At 17.

114 Convention on the law applicable to contractual obligations opened for signature in Rome on 19 June 1980, [1998] O.J. C 27/36 (consolidated version).

${ }^{115}$ See First Protocol on the interpretation by the Court of Justice of the European Communities of the Convention on the law applicable to contractual obligations, opened for signature in Rome on 19 June 1980 done at Brussels on 19 December 1988, [1998] O.J. C 27/47 (consolidated version), Articles 1 and 2.

${ }^{116}$ See Second Protocol conferring on the Court of Justice of the European Communities certain powers to interpret the Convention on the law applicable to contractual obligations, opened for signature in Rome on 19 June 1980 done at Brussels on 19 December 1988, [1998] O.J. C 27/52 (consolidated version), Article 3.

${ }_{117}$ A note on new Article 68 para. 3 EC Treaty is found at 18 , above.
} 
courts of last resort are to be given the power to ask the Court for an interpretation of provisions contained in the respective Convention, if a conflict arises between a court decision and interpretations given in a judgment of another domestic tribunal or of the Court of Justice, and if that decision and the conflicting judgment have become final. ${ }^{118}$ The Court's ruling in response to the request affects none of the preceding decisions. It is therefore by way of complementary Member State agreements that a procedure of this kind was initially introduced to the legal system of the Community.

\section{Protection of intellectual property}

In another field, recent Community legislation has established Community intellectual property rights accompanied by judicial regimes regarding their enforcement. ${ }^{119}$ The rights are granted - and also invalidated, as the case may be - by independent Community agencies whose decisions may be challenged before the Court of Justice. ${ }^{120}$ According to Article 3 (c) of the Council Decision establishing a Court of First Instance as amended by Council Decision 93/350/Euratom, ECSC, EEC, ${ }^{121}$ jurisdiction in these actions is exercised at first instance by the CFI. ${ }^{122}$ In order to challenge a decision of the OHIM or the CPVO, appeal must first be taken to the Boards of Appeal within the respective agency. ${ }^{123}$ These appeal divisions, although included in the organisational

${ }^{118}$ See Article 4 of the Protocol on the interpretation by the Court of Justice of the Brussels Convention, supra n. 106, as well as the corresponding provisions of the First Protocol on the interpretation by the Court of Justice of the Rome Convention, supra n. 115, and the draft Proto$\mathrm{col}$ on the interpretation by the Court of Justice of the European Communities of the Convention on jurisdiction and the recognition and enforcement of judgments in matrimonial matters, supra $\mathrm{n}$. 111.

${ }^{119}$ See Council Regulation (EC) No $40 / 94$ of 20 December 1993 on the Community trade mark, [1994] O.J. L 11/1 [hereinafter Community Trade Mark Regulation], and Council Regulation (EC) No 2100/94 of 27 July 1994 on Community plant variety rights, [1994] O.J. L 227/1 [hereinafter Community Plant Variety Rights Regulation]. Council Regulation (EC) No 6/2002 of 12 December 2001 on Community designs, [2002] O.J. L 3/1 [hereinafter Community Design Regulation] has entered into force on 6 March 2002.

${ }^{120}$ Agencies are the Office for Harmonisation in the Internal Market (Trade Marks and Designs) (OHIM) in Alicante, Spain, and the Community Plant Variety Office (CPVO) in Angers, France.

${ }_{121}$ See Council Decision 93/350/Euratom, ECSC, EEC amending Council Decision 88/591/ECSC, EEC, Euratom establishing a Court of First Instance of the European Communities, supra n. 82, Article 1.

${ }^{122}$ It was found necessary to include in the Community Trade Mark Regulation a $13^{\text {th }}$ Recital confirming that 'the jurisdiction which this Regulation confers on the Court of Justice [...] shall accordingly be exercised at the first instance by the [CFI]'. A similar reference is only found accompanying amendments to the Community Plant Variety Rights Regulation in Council Regulation (EC) No 2506/95 of 25 October 1995 amending Regulation (EC) No 2100/94 on Community plant variety rights, [1995] O.J. L 258/3.

${ }_{123}$ See Articles 57 - 63 Community Trade Mark Regulation and the corresponding provisions of the Community Design Regulation. Also, see Articles 67 - 73 Community Plant Variety Rights 
structure of an administration, exercise an independent function, and the status of their members may be considered resembling the status of judges (e.g. independence; exclusion on the basis of participation in the previous administrative proceedings; and exclusion for conflicts of interest). ${ }^{124}$ According to the general rules, further appeal on points of law only lies from decisions of the CFI to the Court of Justice as a court. One may thus infer that as concerns administrative decisions in respect of Community intellectual property rights, judicial review is presently three-tiered.

Enforcement of intellectual property, on the other hand, is to be carried out almost exclusively by Member State courts. Community plant variety rights are thus protected by a number of harmonised enforcement procedures, ${ }^{125}$ while the CPVO retains permanent exclusive jurisdiction as regards the validity of a right. National courts are required to await the final decision in nullity or cancellation proceedings or otherwise have to treat the right as valid. ${ }^{126}$

In contrast, the validity of Community trade marks and Community designs may be put in issue by way of counterclaim raised in connection with an infringement action. $^{127}$ It is a generally mandatory counterclaim as required for preserving the Community rights' unitary character: any declaration of invalidity necessarily affects a right in respect of the whole Community. ${ }^{128}$ Entrusted with jurisdiction - shared with the OHIM - concerning the validity of trade marks and designs, domestic courts are called upon to apply a sophisticated set of rules of Community law. Therefore, both the Community Trade Mark Regulation and the Community Design Regulation do not only aim at harmonising enforcement proceedings but also at ensuring the necessary expertise for litigation based on the rights they establish. Each Member State is required to designate as limited number as possible of its courts to exercise the function of so-called 'Community Trade Mark Courts'129 (respectively 'Community Design Courts'130) of first and second instance. Without recourse to any appeal body at the level of the Community,

Regulation where the rules on the jurisdiction of the Court of Justice are now brought into line with the provisions for trade marks and designs.

${ }^{124}$ See generally C. Wadlow, Enforcement of Intellectual Property in European and International Law (London: Sweet \& Maxwell, 1998) at $244-245$.

${ }_{125}$ See Articles 94 - 104 Community Plant Variety Rights Regulation.

${ }^{126}$ Articles 105 and 106 (2) Plant Variety Rights Regulation.

${ }^{127}$ See Articles 95 and 96 Community Trade Mark Regulation and Articles 84 and 85 Community Design Regulation.

${ }^{128}$ See Article 1 (3) Community Design Regulation. See also Article 1 (2) Community Trade Mark Regulation and Article 2 Community Plant Variety Rights Regulation.

129 Article 91 Community Trade Mark Regulation.

${ }^{130}$ Article 80 Community Design Regulation. 
preliminary references according to Article 234 EC Treaty are the only way to obtain a ruling of a central Community institution on the legal effects of a Community trade mark or design. This does not deviate from the general judicial architecture, but it is only here that national courts applying Community law are appropriately referred to as 'Community courts'.

Finally, the Community has almost permanently pursued a unitary patent, more recently concentrating on an institutional link to the patent system under the auspices of the European Patent Organisation. ${ }^{131}$ Granting procedures provided by this international organisation offer bundles of separate national patents whose validity and enforcement in the territory of a particular Contracting State are subject to the legal order of that State. $^{132}$

According to the European Commission's most recent approach, ${ }^{133}$ the Community would become a member of the European Patent Organisation, leaving the grant of patents designated to take effect throughout the Community entirely in the hands of this entity. The legal effects (including the continued existence and enforcement of the patent) would then be governed by Community law, patent litigation being exclusively assigned to a central Community Intellectual Property Court with jurisdiction in first and second instance. These ambitious proposals have been made in the wake of an apparent failure of the latest of the Member State agreements concerning patents: the Community Patent Convention of 1989 entailed a different patent granting scheme and the introduction of a Common Appeal Court, which would have exercised limited jurisdiction on the appellate level only besides hearing preliminary references concerning the interpretation of the Convention. ${ }^{134}$ It had been disapproved of by patent proprietors for lack of legal certainty in enforcement procedures, ${ }^{135}$ and ratification of the instruments ultimately halted. However, the example of the striven-for Community patent system

\footnotetext{
${ }^{131}$ For a historical review of some draft agreements, see C. Wadlow, supra n. 124 at $215-222$.

${ }^{132}$ See Convention on the grant of European patents of 5 October 1973, [1982] U.K.T.S. No. 16. A consolidated version can be downloaded from the website of the European Patent Office, <http://www.european-patent-office.org/epc/pdf_e.htm>.

${ }_{133}$ See draft Council Regulation on the Community patent (Commission proposal of 1 August 2000), COM (2000) 412 final.

${ }^{134}$ The draft Community Patent Convention became an integral part of the Agreement relating to Community patents - Done at Luxembourg on 15 December 1989, [1989] O.J. L 401/1, to which was also annexed the Protocol on the settlement of litigation concerning the infringement and validity of Community patents, [1989] O.J. L 401/34, that included the establishment of this court.

${ }^{135}$ See especially European Commission, Promoting innovations through patents - The follow-up to the Green Paper on the Community patent and the patent system in Europe (Communication to the Council, the European Parliament and the Economic and Social Committee of 5 February 1999), COM (1999) 42 final, at $8-12$.
} 
indicates some preparedness of the European Union for creating a specialised court with only limited supervision by the Court of Justice ${ }^{136}$ and thus for dividing off some of the highest Community jurisdiction.

\section{F. Conclusion}

Since the Court of Justice assumed jurisdiction under the EEC and EAEC Treaties, its procedures and organisation have been subject to only a few, though not insignificant changes. As a major structural modification, the CFI was introduced in order to relieve the Court of Justice as a court of the typically complex fact-finding in some circumscribed categories of cases. Subsequent amendments have prepared the ground for more tasks, but neither have they so far been designated nor has the CFI ever formally acquired the independence of a full-blown Community institution.

As was the attachment of the CFI, some changes to the Court of Justice have been made in the name of both the protection of individual interests and the efficiency of the Court. It was reported above that the Court itself regards effective judicial protection as a fundamental principle of the Community legal order. However, affording individuals better judicial protection and enhancing the efficiency of the highest court in a given legal system may be incompatible goals to some extent. Some institutional developments have been further complicated by what appears to be concessions to the sovereignty of the Member States. The Community judicial system has thus lost the uniform structure of the founding years. The former simplicity of the jurisdiction of the Court of Justice as a whole has disappeared.

However, the most important development seems to concern the authority of the Court of Justice and its reputation among national judiciary. Since the early days of the EEC, the Court has successfully defended itself against any attempts by the Member States to limit it to an international law tribunal of sorts. ${ }^{137}$ The Court even created a new type of infringement procedure by introducing a remedy for damages caused by an

\footnotetext{
${ }^{136}$ As far as the draft Council Regulation on the Community Patent, supra $\mathrm{n} .133$, is concerned, see the Explanatory Memorandum at 17 - 18. See also C. Wadlow, supra n. 124 at 235.

${ }^{137}$ Compare e.g. the unsuccessful submissions by the governments of Belgium, Germany, the Netherlands, and in the second case Italy, in Judgment of 5 February 1963, Van Gend en Loos V Nederlandse Administratie der Belastingen, supra n. 46, and Judgment of 15 July 1964, Costa v ENEL, Case 6/64 [1964] E.C.R. 585.
} 
improper application of Community law. It is suggested here that this happened against the will of the Member States. ${ }^{138}$

It was also necessary for the Court of Justice to overcome some resistance or even open defiance by particular domestic courts, but it seems to be accepted now throughout the European Union that the Court is the supreme interpreter of European Union law and that it has exclusive power to declare legal acts of the Communities invalid. This might be the result of the generally prudent and strategic reaction of the Court wherever it faced conflict - and of the Courts efforts to improve mutual understanding by way of conferences and informal meetings with national judiciary. ${ }^{139}$ It may have helped, furthermore, that suggestions by Member State courts influence the jurisprudence of the Court noticeably and at times serve as the basis of, rather than just a stimulus for, a particular interpretation of Community law. ${ }^{140}$ In any case, one may say that the Court's strategy has in fact fostered respect for its authority, and that it has brought into being a spirit of co-operation among the judiciaries at the domestic and the Community levels all of whom are entrusted with applying the Community legal order.

\footnotetext{
${ }^{138}$ During the intergovernmental conference which led to the conclusion of the Treaty of Amsterdam the United Kingdom, indeed, proposed to amend the Treaties to the effect of limiting state liability for loss or damages to cases of serious and manifest breach of Community law under all circumstances, and of excluding any such claims dating from more than three years before the commencement of legal proceedings; see Government of the United Kingdom, IGC 1996: Memorandum by the United Kingdom on the European Court of Justice (July 1996) Annexes A and B. See also the Reports for the Hearing in the cases Francovich and Others v Italy, supra n. 64 at I5369, and Brasserie du Pêcheur v Germany and R. v Secretary of State for Transport, ex parte Factortame and Others, supra n. 64 at $1-1047$, where the German government is repeatedly reported as arguing that the general liability of Member States for infringements of Community law could only be established by way of legislative measures.

${ }^{139}$ See L. N. Brown \& T. Kennedy, supra n. 52 at 401 and 230 , and H. G. Schermers \& D. F. Waelbroeck, supra n. 41 at $\S 690$.

${ }^{140}$ The Court's adoption of the acte clair doctrine beginning with Judgment of 6 October 1982, CILFIT V Ministry of Health, Case 283/81 [1982] E.C.R. 3415 at 3430, is often referred to as an example for the latter type of interaction but see G. F. Mancini \& D. T. Keeling, "From C/LFIT to ERT: The Constitutional Challenge facing the European Court" (1991) 11 Yearbook of European Law 1 at $4-5$.
} 


\section{Part 2 The need for reform}

In the preceding Part 1, I have examined the historical development of the European Union judicial architecture from the legal perspective, including the notion of co-operation between the courts of the Member States on the one hand and the Community judiciary on the other. The emerging authority of the Court of Justice, in itself a question of fact, has been pointed out at the end. The present part deals with the development of factual aspects in the environment of which the Court of Justice is increasingly unable to accomplish its tasks fully. It will become clear that the problems are structural in nature and that except for appropriate changes the entire legal system of the Communities will be put at risk.

\section{A. Case-load}

The most obvious single circumstance with obstructive effect to the performance of judicial functions is the infamous workload of both the CFI and the Court of Justice. Figures for the year 2000 are as follows: ${ }^{1}$

\begin{tabular}{|l|c|c|c|}
\hline & $\begin{array}{c}\text { Cases completed } \\
\text { [Judgments*] }\end{array}$ & Cases brought & $\begin{array}{c}\text { Cases pending } \\
\text { as at 31 }{ }^{\text {st }} \text { Dec. }\end{array}$ \\
\hline Court of Justice & $526[273]$ & 503 & 873 \\
\hline Court of First Instance & $344[116]$ & 398 & 786 \\
\hline
\end{tabular}

* Without orders terminating proceedings by judicial determination (e.g. for inadmissibility) and other orders (e.g. removal from register). The figures for completion by judgment take account of the joining of cases with each series of joined cases being taken as one case. When taking the joining of cases into consideration, the overall number of final decisions is 463 for the Court of Justice and 258 for the Court of First Instance.

It is an exception to the data of recent years that the Court of Justice as a court was able to have a throughput about matching the number of new cases. ${ }^{2}$ This has done little to

\footnotetext{
${ }^{1}$ Source of all figures except where indicated otherwise: Court of Justice, Annual Report (extracts) - Statistics of Judicial Activity of the Court of Justice, Statistics of Judicial Activity of the Court of First Instance, 1998, 1999, $2000<$ http://curia.eu.int/en/pei/rapan.htm>.

${ }^{2}$ In 1998 and 1999 the number of completed cases trailed the number of new cases by 65 and 148 respectively.
} 
the stock of cases still pending before the Court of Justice and the CFI, the combined numbers of which amounted to 1,659 at the end of 2000 - after 1,755 for the year 1998 and 1,628 in 1999.

The overburdening of the judicial institutions is not a temporary phenomenon, nor is it confined to the European Union in particular. The general trend may be linked to a growing preparedness for going to court in the context of increasingly complex social relationships and higher economic and cultural standards. ${ }^{3}$ Nevertheless, the fact that proceedings before the Court of Justice (as a whole) have outgrown its capacities is largely caused by factors specific to the legal system of the European Union. The factors have been analysed by various commentators and continue to indicate an even further expansion of Community litigation in the future. ${ }^{4}$ It suffices here to produce a summary description of the causes some of which will be returned to later as involving structural issues beyond the mere overflow in the case-load: ${ }^{5}$

(1) successive accession of new members to the European Union;

(2) regular extension of Community action to new fields of application including both the harmonization of national laws and the incorporation of new topics into Community law; as in the case of intellectual property protection or judicial cooperation in civil matters, some of these areas may give rise to intense litigation;

\footnotetext{
${ }^{3}$ See Working Party on the Future of the European Court of Justice, Report by the Working Party on the Future of the European Communities' Court System (January 2000) <http:/leuropa.eu.int/ comm/igc2000/offdoc/discussiondocs/index_en.htm> at 2. The Working Party was established by the European Commission, and it consisted of Ole Due, former President of the Court of Justice, José Luis Da Cruz Vilaça, former Advocate-General and former President of the CFI, and three further members, among others, with experience at the Court of Justice: Yves Galmot, Ulrich Everling and Lord Slynn of Hadley.

${ }^{4}$ See G. C. Rodriguez Iglesias, "The EC Court of Justice and the Institutional Reform of the European Union" (Speech, April 2000) <http://curia.eu.int/en/txt/intergov/rod.pdf> at 3 and S. E. Strasser, "Evolution \& Effort: Docket Control and Preliminary References in the European Court of Justice" (1996) 2 Columbia Journal of European Law 49 at 54.

${ }^{5}$ For more details, see T. Koopmans, "The Future of the Court of Justice of the European Communities" (1991) 11 Yearbook of European Law 7 at $18-19$; R. Streinz and S. Leible, "Die Zukunft des Gerichtssystems der Europäischen Gemeinschaft - Reflexionen über Reflexionspapiere" [2001] Europäisches Wirtschafts- \& Steuerrecht 1 at $1-2$; Court of Justice \& Court of First Instance, The Future of the Judicial System of the European Union (Proposals and Reflections (Discussion Paper, 10 May 1999) <http://curia.eu.int/en/txt/intergov/ave.pdf> [hereinafter "1999 Discussion Paper"] at $6-8$. For the following, see also J. L. da Cruz Vilaça \& L. M. Pais Antunes, "The Court of First Instance of the European Communities: A Significant Step towards the Consolidation of the European Community as a Community Governed by the Rule of Law" (1990) 10 Yearbook of European Law 1 at 13, and Members of the EC Section of the British Institute's Advisory Board chaired by The Rt. Hon. the Lord Slynn of Hadley, The Role and Future of the European Court of Justice (London: The British Institute of International and Comparative Law, 1996) at $2-3$.
} 
(3) expansion of the body of Community law in general, which increasingly penetrates into the economic and social relationships of European Union citizens; also, whether directly applicable or not, the Community legal order comprises more and more highly complex provisions;

(4) growing awareness by lawyers and citizens alike of rights and obligations under Community law and an increasing familiarity with mechanisms for the defence of such rights;

(5) institutional developments such as monetary union and the creation of Europol and the European Central Bank;

(6) the sum of new powers and additional jurisdiction of the Court of Justice resulting from treaty amendments and separate Member State agreements;

(7) an actual or potential increase in the proportion of appeals against judgments delivered by the $\mathrm{CFI}$;

(8) more proceedings instituted by the European Commission against Member States for failure to comply with Community law.

Indeed, infringement proceedings against Member States have risen in numbers to constantly account for about one-third of the cases brought before the Court of Justice as a court. This may be based on the growing complexity of the application of Community law, yet it is to some extent simply caused by the unwillingness of Member States to fulfil their obligations. ${ }^{6}$ In more than a few cases, the Member States involved are not seriously disputing the infringement. ${ }^{7}$ Elaborate proceedings before the Court may thus have the sole purpose of providing the final declaration of a breach of Community law. ${ }^{8}$

Nevertheless, the largest single source of cases, which is the number of references for a preliminary ruling, signifies the actual close co-operation between the national courts and the Court of Justice, and thus it stands for the very success of the judicial system. Preliminary references make up roughly half of the workload of the Court of Justice as a court, and in the years from 1998 to 2000, they amounted to between one-quarter and more than one-third of all proceedings before the Court of Justice and the CFI taken as one.

\footnotetext{
${ }^{6}$ See R. Streinz \& S. Leible, ibid. at 11.

${ }^{7}$ See Working Party on the Future of the European Court of Justice, supra n. 3 at 25.

${ }^{8}$ For a comparison of the Commission's role in infringement proceedings under the EC and EAEC Treaties on the one side and under the ECSC Treaty on the other, see Part 1 Section B, above.
} 


\section{B. Length of proceedings}

An inadequate overall number of proceedings terminated compared to the number of new proceedings, and the following backlog of cases, have led to significant delay in both the Court of Justice and the CFI. In 1998, 1999 and 2000, references for a preliminary ruling to be decided by way of judgment or other judicial determination took a constant average of some $21 \frac{1}{2}$ months. In the same period, the average time taken for direct actions to come to decision in the Court of Justice ${ }^{9}$ rose from 21 months to almost 24 months. Available figures for the length of proceedings before the $\mathrm{CFI}$ are not equally representative as they include all cases no matter the way they have been terminated: in 2000, proceedings dealing with intellectual property lasted about nine months on average, staff cases took $151 / 2$ months and other actions took $271 / 2$ months, the latter up from averages of about 20 months in 1998 and $121 / 2$ months in 1999 . Yet, for a case at the CFI to come to actual judgment, an average time of more than 32 months is reported for $1998 .{ }^{10}$

Instead of comparing today's delays with the raw figures from previous years, Neville March Hunnings provides an illustration of a well-working procedure for preliminary references, which shall be reproduced in the following:

[l]n 1974, the position was quite different. In Case 41/74, Van Duyn v. Home Office, the English High Court gave judgment on 14 February 1974, the reference order was made by it on 1 March, it was lodged at the ECJ Registry on 13 June, the Advocate General gave his opinion on 13 November and the ECJ gave its judgment on 4 December 1974. The whole process took some $91 / 2$ months, of which 4 months represented delays in England. The Advocate General drafted and presented his opinion 5 months after the case first reached the Registry and the full Court (with all 9 Judges) took a further $21 / 2$ weeks on what was a politically and legally sensitive case of multiple first impression, involving a major development of the law (direct effect of directives) and consideration for the first time of an important concept (public policy in immigration), an important directive (Dir. 64/221) and an important concept in that directive (personal conduct). ${ }^{11}$

As much as these may be considered successful times for the court system of the Communities, the lengthening of proceedings today endangers the performance of its functions. Moreover, with some of the aforementioned factors potentially pushing the Court's case-load even higher, the situation is likely to aggravate in the future.

With regard to direct actions and especially those against Member States for failure to fulfil their obligations under the Treaties, inefficient procedures easily translate

\footnotetext{
${ }^{9}$ Decisions other than orders terminating a proceeding by removal from register, declaration that the case will not proceed to judgment or referral to the CFI.

${ }^{10}$ See Working Party on the Future of the European Court of Justice, supra n. 3 at 8.

${ }^{11}$ N. M. Hunnings, The European Courts (London: Cartermill, 1996) at 162.
} 
into ineffectiveness of the institution. As long as a final decision is delayed, an illegal practice may continue. ${ }^{12}$ In the case of an infringement proceeding according to Article 226 EC Treaty (ex Article 169 EC Treaty), it is necessary, in addition, to consider the length of the pre-litigation phase and also the period granted to Member States in order to implement an adverse judgment. ${ }^{13}$ If it takes several years to ensure that a Member State complies with particular rules of Community law, the procedural arrangements seem to be rather ineffective, and one may doubt the credibility of the institution that is to safeguard the uniform application and observance of such rules. ${ }^{14}$

The consequences of delay in the Court of Justice are not less significant as concerns the preliminary rulings procedure. It is generally expected that national courts will reconsider their willingness to make references in the light of their need to conduct proceedings as fast and efficient as possible, and that ultimately they may be deterred from involving the Court in the solution of important points of Community law. ${ }^{15}$ The spirit of judicial co-operation, which ensures that appropriate questions are considered by the supreme interpreter of the Community legal order, and thus, the functioning of the entire system are at risk.

Finally, one's concern must turn to the length of proceedings as a question of the distribution of justice in those cases where the procedure is intended to protect individual interests. If the expression "justice delayed is justice denied ${ }^{16}$ is not currently applicable to the Court, then at the very least a further lengthening of the proceedings in the future could infringe on the right 'to a fair and public hearing within a reasonable time' according to Article 6 (1) of the European Convention on human rights. ${ }^{17}$ This and other rights set forth in the ECHR the European Union has bound itself to respect by virtue of Article 6 (2) TEU (ex Article F (2) TEU), although only long after the Court of Justice had begun to regard the Convention and related instruments as a source of the Community legal

\footnotetext{
${ }^{12}$ Interim measures according to Articles 242, 243 EC Treaty (ex Articles 185, 186 EC Treaty) and the corresponding provisions of the EAEC and ECSC Treaties are exceptional.

${ }^{13}$ See Members of the EC Section of the British Institute's Advisory Board chaired by The Rt. Hon. the Lord Slynn of Hadley, supra n. 5 at 3, and J. L. da Cruz Vilaça \& L. M. Pais Antunes, supra n. 5 at 12.

${ }_{14}^{14}$ See J. L. da Cruz Vilaça \& L. M. Pais Antunes, supra n. 5 at 12.

${ }^{15}$ See e.g. J. L. da Cruz Vilaça \& L. M. Pais Antunes, ibid.; T. Koopmans, supra n. 5 at 18; Members of the EC Section of the British Institute's Advisory Board chaired by The Rt. Hon. the Lord Slynn of Hadley, supra n. 5 at 3; G. C. Rodríguez Iglesias, supra n. 4 at 2; S. E. Strasser, supra n. 4 at 53 .

${ }^{16}$ See T. Millett, The Court of First Instance of the European Communities (London: Butterworths, 1990 ) at 1 , and T. Koopmans, supra n. 5 at 31.

${ }^{17}$ Convention for the protection of human rights and fundamental freedoms signed in Rome on 4 November 1950, [1969] E.T.S. No. 5 [hereinafter ECHR].
} 
order. $^{18}$ A provision corresponding to Article 6 (1) ECHR is also part of the Charter of Fundamental Rights, solemnly proclaimed on 7 December 2000 by the European Parliament, the Council and the European Commission. ${ }^{19}$ Finally, the Member States all of whom are Members of the Council of Europe having agreed to the ECHR might find themselves in a conflict of obligations, their courts being required to await preliminary rulings under the Treaties although they would not be given in a timely manner. ${ }^{20}$

In summary, one can say that an increasing case-load and a further lengthening of proceedings jeopardise the functioning, credibility and legitimacy of the procedures of the Court of Justice and its effectiveness as an institution. This cannot but undermine the Court's normative authority. Without this authority, the Court will ultimately fail to ensure the uniform application and observance of the Community legal order and to protect individual interests where appropriate.

\section{Enlargement}

The European Union faces an unprecedented number of applications for accession, and it is preparing itself for the participation of up to 27 Member States in the foreseeable future. ${ }^{21}$ It can be expected that each step of enlargement will eventually be followed by an increase in the volume of litigation based on Community law - with obvious effects for the number of cases brought before the Court of Justice. ${ }^{22}$ More staff and the additional judges arriving in the Court of Justice and the CFI with every accession of a new

\footnotetext{
${ }^{18}$ See Court of Justice, Judgment of 14 May 1974, Nold v Commission, Case 4/73 [1974] E.C.R. 491; Judgment of 28 October 1975, Rutili v Minister for the Interior, Case 36/75 [1975] E.C.R. 1219; Judgment of 13 December 1979; Hauer v Land Rheinland-Pfalz, Case 44/79 [1979] E.C.R. 3727. See also Judgment of 15 May 1986, Johnston v Chief Constable of the Royal Ulster Constabulary, Case 222/84 [1986] E.C.R. 1651, quoted at 12, above. The Court recently had to test the duration of a case before the CFI against the standards of the ECHR, and for doing so it drew an analogy to the case law of the European Court of Human Rights; see Court of Justice, Judgment of 17 December 1998, Baustahlgewerbe v Commission, C-185/95 P [1998] E.C.R. I-8417 at 1-8499.

${ }^{19}$ See Charter of Fundamental Rights of the European Union, Nice, 7 December 2000, [2000] O.J. C 364/1, Article 47. The legal status and effects of the Charter are not yet decided; see the discussion at 37 , below.

${ }^{20}$ So far, though, the European Court of Human Rights has refused to take into consideration the length of time taken by a preliminary ruling under Article 234 EC Treaty in its assessment of the delay of the national proceedings which give rise to the reference to the Court of Justice; see European Court of Human Rights, Judgment of 26 February 1998, Pafitis and Others v Greece, Application No. 20323/92 ECHR Reports 1998-| 436 at 459.

${ }^{21}$ See Declaration (No. 20) on the enlargement of the European Union adopted by the Conference of the Representatives of the Governments of the Member States, Final Act of Nice done on 26 February 2001, [2001] O.J. C 80/70 at 80.

${ }^{22}$ See especially Court of Justice \& Court of First Instance, "1999 Discussion Paper", supra n. 5 at 6 .
} 
Member State may help conducting more proceedings. But at the same time, working conditions will suffer from institutional and structural difficulties of enlargement.

First, it has been repeatedly stated that a large increase in the number of judges will be counterproductive for the operation of the institution..$^{23}$ As regards the Court of Justice as a court, much of the authority of the decisions is said to derive from its collegiate working method and from each judge's personal contribution to the discussion of the case. ${ }^{24}$ Thus, the quality of judgments will be at risk, if personal interaction is hampered by the sheer size of the plenum ${ }^{25}$ or what may be called the transformation from a judicial collegiate to a 'deliberative assembly'. ${ }^{26}$ On the other hand, increasing the number of chambers or chamber proceedings would result in greater fragmentation, thus jeopardising the consistency of the case law at the highest level of the court system. ${ }^{27}$ These operational and functional concerns do not apply to the CFI as it is only exceptionally sitting in plenary session and as its decisions may be appealed against before the Court of Justice. ${ }^{28}$ However, any enlargement of either one or both of the courts will make it more difficult to manage the services and the personnel within a combined judicial institution. ${ }^{29}$ Thus, enlargement will override the primary purpose of attaching the $\mathrm{CFI}$ to the Court of Justice while maintaining a unitary institutional structure.

Every accession to the European Union, secondly, means an additional challenge for the due consideration of all participating legal traditions and the Member

\footnotetext{
${ }^{23}$ See e.g. Working Party on the Future of the European Court of Justice, supra n. 3 at 9.

${ }^{24}$ See P. J. G. Kapteyn, "The Court of Justice of the European Communities after the Year 2000" in D. Curtin \& T. Heukels, eds., Institutional Dynamics of European Integration - Essays in Honour of Henry G. Schermers, vol. 2 (Dordrecht: Martinus Nijhoff, 1994) 135 at 137, and D. Edward, "How the Court of Justice Works" (1995) 20 European Law Review 539 at $555-556$.

${ }^{25}$ See T. Koopmans, supra n. 5 at 24.

${ }^{26}$ See Court of Justice, Report on Certain Aspects of the Application of the Treaty on European Union (22 May 1995), reprinted in German [1995] Zeitschrift für Europäisches Gemeinschaftsrecht 316 [hereinafter "1995 Report"] at 319; accounts on the report are given in English language by A. Arnull, "The Community Judicature and the 1996 IGC" (1995) 20 European Law Review 599, and P. Craig, "The Road to the 1996 Intergovernmental Conference: The Contribution of the European Court of Justice and the Court of First Instance" [1996] Public Law 13.

${ }^{27}$ See N. M. Hunnings, supra n. 11 at 161; Members of the EC Section of the British Institute's Advisory Board chaired by The Rt. Hon. the Lord Slynn of Hadley, supra n. 5 at 45; G. C. Rodriguez Iglesias, supra n. 4 at 1.

${ }^{28}$ See Court of Justice, "1995 Report", supra n. 26 at 319 . In its own report on the operation of the Treaty of European Union, the CFI indeed proposed to raise the number of its members, see Court of First instance, Contribution for the Purposes of the 1996 Intergovernmental Conference (22 May 1995), reprinted in German [1995] Zeitschrift für Europäisches Gemeinschaftsrecht 320 at $321-322$.

${ }^{29}$ See W. van Gerven, "The Role and Structure of the European Judiciary now and in the Future", (1996) 21 European Law Review 211 at 217.
} 
States' diverse political and economic conditions. The principle that both the Court of Justice and the CFI are composed of one judge per Member State has as its strength that precisely these different backgrounds are reflected in the courts' decisions-making process. ${ }^{30}$ The representation of varied legal education and thinking is considered as fuelling the judgments' necessary integrative qualities and as ensuring the operability of Community law in all legal systems. ${ }^{31}$ Yet, with less and less homogeneity among the Member States and the judges, common legal grounds diminish and consensus will be increasingly difficult to achieve. ${ }^{32}$

Lastly, enlargement will aggravate the language problem in the Court of Justice as a whole. According to the principle of linguistic equality ${ }_{,}{ }^{33}$ the language of a case may be one of the eleven official Community languages or Irish. ${ }^{34}$ Consequently, it requires enormous expenditures of money and time to translate all documents into the working language of the Court and to supply translations of all the decisions as required for their publication in each official language..$^{35}$ To some extent, the amount of translation work is primarily a matter of resources of the Court's non-legal services. ${ }^{36}$ However, the arrival of new languages may become more significant than a technical issue. $L$. Neville Brown and Tom Kennedy point out an increase to a mind-boggling number of 240 possible combinations for translation and interpretation for an expected expansion to 21 Member States, in the next round of enlargement only. ${ }^{37}$ The least one may infer is that a growing number of official languages - as the greater variety in the Member States' legal and social systems - will complicate rather than simplify the carrying out of the Court's adjudicative tasks.

\footnotetext{
${ }^{30}$ See D. Edward, supra n. 24 at $548-549$.

31 See R. Streinz \& S. Leible, supra n. 5 at 5, and U. Everling, "The Court of Justice as a Decisionmaking Authority" (1984) 82 Michigan Law Review 1294 at 1295 - 1296.

${ }^{32}$ See U. Everling, supra n. 31 at 1295, and N. M. Hunnings, supra n. 11 at 161 ; see also A. Arnull, "Judicial Architecture or Judicial Folly? The Challenge facing the European Union" (1999) 24 European Law Review 516 [hereinafter "Challenge"] at 516.

${ }^{33}$ See Regulation No 1 determining the languages to be used by the European Economic Community, 15 April 1958, in Dutch, French, German and Italian [1958] O.J. L 17/385.

${ }^{34}$ See Rules of Procedure of the Court of Justice of the European Communities of 19 June 1991, [1991] O.J. L 176/7 and [1992] O.J. L 383/1 (corrigenda) [hereinafter Rules of Procedure (Court of Justice)], Article 29, and Article 35 of the Rules of Procedure (CFI).

${ }^{35}$ See D. Edward, supra n. 24 at $545-548$, and Working Party on the Future of the European Court of Justice, supra n. 3 at $9-10$.

${ }^{36}$ See Court of Justice \& Court of First Instance, "1999 Discussion Paper", supra n. 5 at 9.

${ }^{37}$ L. N. Brown \& T. Kennedy, L. N. Brown and F. G. Jacobs' The Court of Justice of the European Communities, $5^{\text {th }}$ ed. (London: Sweet $\&$ Maxwell, 2000) at 391.
} 


\section{Evolution of the Community legal order}

Further questions as to the future of the judicial system arise from certain developments in Community law.

\section{Proliferation and growing complexity}

If the number of Member States and European Union citizens is rising and if new measures are adopted in areas previously not covered by Community action, the body of Community law will continue to expand in terms of both material scope and territorial and personal applicability. It was noted above ${ }^{38}$ that therefore the volume of proceedings instituted under Community law will in all likelihood further increase in the future. The quantitative effect is accompanied by an ongoing qualitative change in the Community legal order. As will be shown in the following, this development might overburden judicial decision-making in itself.

Community law penetrates into more and more specialist fields of the law by way of harmonisation, supplementation or substitution of national rules. As a consequence, preliminary references and direct actions raise increasingly complex and technical questions of law and, as regards the latter type of procedure, also of fact. ${ }^{39}$ In addition, it will become more difficult, in the context of enlargement, to solve complex legal problems in a way that is operable in the legal systems of all Member States. Apart from different national backgrounds, the present Community judiciary cannot not in person represent legal experience and specialisation to the same extent as problems of Community law become varied and detailed coincidentally. ${ }^{40}$ This is occasionally recognised by former judges of the Court. ${ }^{41}$ At some point, however, lack of personal expertise on the bench cannot but diminish the legality and authority of judgments. The evolution of Community law may thus strain the performance of judicial functions within the present all-embracing structure.

\footnotetext{
${ }^{38}$ At $28-29$.

${ }^{39}$ See R. Streinz \& S. Leible, supra n. 5 at 6.

${ }^{40}$ See R. Streinz \& S. Leible, ibid.

${ }^{41}$ See D. Edward, supra n. 24 at 549, and U. Everling, "Empfiehlt es sich, das System des Rechtsschutzes und der Gerichtsbarkeit in der Europäischen Gemeinschaft weiterzuentwickeln?" (Comment for the $60^{\text {th }}$ German Lawyers' Conference, 21 September 1994) in Ständige Deputation des Deutschen Juristentages, ed., Verhandlungen des Sechzigsten Deutschen Juristentags, vol. 2, book 1 (München: Beck, 1994) N 9 at N 14.
} 


\section{Protection of fundamental rights}

As necessary for the unconditional priority of Community law over rules of domestic law of any (including constitutional ${ }^{42}$ ) status, the respect for fundamental rights has evolved into 'an integral part of the general principles of law protected by the Court of Justice. ${ }^{43}$ Following the case law of the Court, the principle of respect for human rights has gradually entered the Treaties as an obligation of the Union and the Member States. ${ }^{44}$ The Court is thus prepared to examine the lawfulness of Community measures and of their execution by national authorities from the perspective of almost any aspect of the life of European Union citizens.

In contrast, there are strict limits for individuals who assert that their rights are infringed to directly access the Court: according to Article 230 para 4 EC Treaty (ex Article 173 para 4 EC Treaty) and the corresponding provisions of the EAEC Treaty, ${ }^{45}$ natural or legal persons may bring actions only against Community decisions addressed to them, 'or against a decision which, although in the form of a regulation or a decision addressed to another person, is of direct and individual concern for the [applicant].' Locus standi of an individual thus seems to depend on the (true) legal form of the measure and on the fact that, if the individual is not addressed by the act, it directly affects and distinguished him from other persons.

However, the Court's case law in view of these requirements is not free of policy considerations concerning docket control and concerning the separation of jurisdiction in preliminary references from the jurisdiction of the CFI in actions for annulment brought by private parties. ${ }^{46}$ Some authors thus consider the rulings of the Court as incoherent, ${ }^{47}$

\footnotetext{
${ }^{42}$ See Court of Justice, Judgment of 15 July 1964, Costa v ENEL, Case 6/64 [1964] E.C.R. 585.

${ }^{43}$ Court of Justice, Judgment of 17 December 1970, Internationale Hande/sgesellschaft v Einfuhrund Vorratsstelle Getreide, Case 11/70 [1970] E.C.R. 1125 at 1134. For this development, see also Court of Justice, Judgment of 12 November 1969, Stauder v Stadt UIm, Case 29/69 [1969] E.C.R. 419, and the cases cited at 32 (note 18), above.

${ }^{44}$ See Article 6 (2) TEU (ex Article F (2) TEU) and Article 7 TEU, which was inserted by the Treaty of Amsterdam and refers to the principles laid down in Article 6 (1) TEU (ex Article $F(1)$ TEU).

${ }^{45}$ Article 146 para 4 EAEC Treaty; under Article 33 para 2 ECSC, standing to challenge recommendations or general decisions is only conferred on undertakings and certain associations.

${ }^{46}$ See P. Beaumont, "European Court of Justice and Jurisdiction and Enforcement of Judgments in Civil and Commercial Matters" (1999) 48 International and Comparative Law Quarterly 223 at 224; C. Harlow, "Towards a Theory of Access for the European Court of Justice" (1992) 12 Yearbook of European Law 213 at 234 - 236; N. A. E. M. Neuwahl, "Article 173 Paragraph 4 EC: Past, Present, and Possible Future" (1996) 21 European Law Review 17 at $29-30$.

${ }^{47}$ See e.g. A. Arnull, The European Union and its Court of Justice (Oxford: Oxford University Press, 1999) [hereinafter "Court"] at 49, and L. N. Brown \& T. Kennedy, supra n. 37 at 146.
} 
or argue that there is a lack of transparency for the citizen. ${ }^{48}$ This is particularly disturbing with regard to a preclusion of preliminary references on the question of the validity of a Community act, if an individual contesting the act in national proceedings could have brought a direct action under Article 230 para 4 EC Treaty within the time limits set out in the fifth paragraph of that provision. ${ }^{49}$ Nevertheless, the principal way of challenging the legality of Community measures is to seek judicial review of an implementing act before a national court, providing for the opportunity to obtain a reference for a preliminary ruling to the Court of Justice. And it is still the only avenue for a private party to institute judicial review of the compatibility of national acts purporting to implement such measures with the rules of Community law.

From the point of view of the respect for fundamental rights, it is at least questionable whether the system provides for an adequate guarantee of effective judicial protection. $^{50}$ It is not assured that national courts, even those of last resort, will always make a reference to the Court of Justice where the protection of human rights within the Community legal order is at stake. Neither does the procedure provide an as satisfactory mechanism for challenging Community measures as a direct action. ${ }^{51}$ In lack of transparency of the available remedies, the enforcement of fundamental rights seems discouraged. This does not correspond to the fact that with the proclamation of the Charter of Fundamental Rights of the European Union, ${ }^{52}$ it has recently been sought to strengthen such protection. So far, the decision on the legal effects of the Charter has been postponed. ${ }^{53}$ It follows from the foregoing that in conjunction with that decision, the European Union has to review the rules on the standing of individuals to bring actions before the Community courts.

\footnotetext{
${ }^{48}$ See N. A. E. M. Neuwahl, supra n. 46 at 27. Neuwahl interprets the case law of the Court so as to reformulate Article 230 para 4 EC Treaty 'as granting locus standi to individuals in actions against: "any Community measure having legal effect addressed to him or by which he is directly and individually concerned"' (emphasis and quotation marks in original), see ibid. at 31.

49 See Court of Justice, Judgment of 9 March 1994, Textilwerke Deggendorf $\vee$ Germany, C188/92 [1994] E.C.R. I-833 at I-853.

${ }^{50}$ See Court of Justice, "1995 Report", supra n. 26 at 319; Members of the EC Section of the British Institute's Advisory Board chaired by The Rt. Hon. the Lord Slynn of Hadley, supra n. 5 at 94; A. Arnull, "Court", supra n. 47 at 49.

${ }^{51}$ See A. Arnull, "Private Applicants an the Action for Annulment under Article 173 of the EC Treaty" (1995) 32 Common Market Law Review 7 at 41-42.

${ }_{52}$ Charter of Fundamental Rights of the European Union, supra n. 19.

${ }^{53}$ See European Council, Presidency Conclusions - Nice European Council Meeting 7, 8 and 9 December 2000, Doc. No. SN 400/00 at 1.
} 


\section{E. Conclusion - The need for structural reform}

Factual parameters such as the rising case-load, further lengthening of proceedings, accession of new Member States and continuing penetration of Community law into diverse and highly complex fields of the law impede the proper administration of justice in the Court of Justice and pose a threat to the future quality of its decisions. In addition, the Court's expanding function to protect fundamental rights casts doubt on the severe restriction of direct access by individuals and on the lack of transparency regarding the requirements for locus standi. The legitimacy of the Court as a judicial institution is at risk, thus endangering the normative authority of the supreme interpreter and ultimate guardian over the application of Community law. As a consequence, the authority of the entire legal system of the Communities may be undermined.

The analysis has shown that the Court faces problems inherent to, indeed, the success story of the judicial system and the successful proliferation of the Community legal order. The Court is a victim of the prestige and credibility of its own performance in so far as this has contributed to the national courts' referring of preliminary questions, and as it has fostered the inclination of Community institutions, Member States, legal persons of public and private law and of individuals to seek protection of their rights under Community law by way of direct actions. ${ }^{54}$ The very acceptance of the Court's function and competences is thus conducive to the overburdening of the institution. On the other hand, enlargement and progress in the European Union's policy and legislative agendas affect the Court of Justice and the CFI beyond the issues of workload and efficiency: the task of adjudicating in Community law is changing in terms of operational challenge and content. It follows that the Community judicial system needs to be restructured as a whole. ${ }^{55}$

Procedural and organisational improvements may have occasionally soothed the symptoms of a burgeoning case-load in the past. Letting the statistics of the CFI speak for themselves, however, it was the structural innovation of creating a second judicial

\footnotetext{
${ }^{54}$ See e.g. T. Koopmans, supra n. 5 at 1 , and J. L. da Cruz Vilaça \& L. M. Pais Antunes, supra n. 5 at 14.

${ }^{55}$ See also European Commission, Reform of the Community Courts (Additional Commission Contribution to the Intergovernmental Conference on Institutional Reform, 1 March 2000) <http:/leuropa.eu.int/comm/igc2000/offdoc/discussiondocs/cont04022000_en.pdf> at 1 - 2; Court of Justice \& Court of First Instance, "1999 Discussion Paper", supra n. 5 at 27; A. Arnull, "Challenge", supra n. 32 at 516 - 517; W. van Gerven, supra n. 29 at 318; V. Lipp, "Entwicklung und Zukunft der Europäischen Gerichtsbarkeit" [1997] Juristenzeitung 326 at 327 et seq.; D. W. J. Scorey, "A new Model for the Communities' Judicial Architecture in the new Union" (1996) 21 European Law Review 224 at 225.
} 
body that has saved the Court of Justice from certain breakdown. ${ }^{56}$ Today, again, reform is to address more than the mere numbers of throughput and turnaround time. In illustration of the foregoing, this part shall be concluded by briefly considering the effects of changes that would leave the present requirements of direct actions and preliminary references as well as the structure of the Community judiciary unaltered.

As to the Court of Justice as a court, speeding up the proceedings by mechanisms of efficiency alone could seriously detract from the profound deliberation and discussion of cases necessitated by its role as the supreme court of a particular legal order. The increased throughput of recent years is already said to come at the expense of an adequate investigation of the disputes' factual backgrounds. ${ }^{57}$ The limits of minimum individual reflection and collegiate discussion have been reached long ago, particularly with respect to cases of constitutional significance. ${ }^{58}$ On the other hand, the Court's jurisprudential capacity, that is the capacity to contribute to the development of the law as a coherent set of legal rules, may be put at risk as the emphasis is shifting towards a jurisdictional function regarding principled and less important matters alike. ${ }^{59}$ This would especially apply, if more proceedings were to be conducted by chambers or if the assistance given to judges by legally qualified staff were increased. Intensifying the use of chambers could jeopardise the consensus on the direction of the case law and diminish the compelling collegiate and representative basis of the Court's pronouncements discussed above. ${ }^{60}$ Delegating more judicial tasks to legal secretaries or deputy reporting judges ${ }^{61}$ would sacrifice some of the persuasive and legitimising effect of a fully

\footnotetext{
${ }^{56}$ For a brief analysis, see P. Mengozzi, "The Protection of Individual Rights and the Court of First Instance of the European Communities" (2000) 23 Fordham International Law Journal 707 at 711 -712 .

57 See A. Arnull, "Refurbishing the Judicial Architecture of the European Community" (1994) 43 International and Comparative Law Quaterly 296 at 297 - 298, and O. Due, "The Court of First Instance" (1988) 8 Yearbook of European Law 1 at $6-7$.

${ }^{58}$ See O. Due, supra n. 57 at 5, and Court of Justice, "1995 Report", supra n. 26 at 318.

${ }^{59}$ See P. J. G. Kapteyn, supra n. 24 at 137, and J. H. H. Weiler, "The European Court, National Courts and References for Preliminary Rulings - The Paradox of Success: A Revisionist View of Article 177 EEC" (EUI Working Paper 85/203) in EUI Working Papers (Badia Fiesolana: European University Institute, 1985) at 5-7.

${ }^{60}$ See text accompanying notes 30 and 31 . See also P. J. G. Kapteyn, supra n. 24 at 140.

${ }^{61}$ The appointment of assistant rapporteurs is envisaged in the Statutes of the Court of Justice, see Protocol on the Statute of the Court of Justice of the European Economic Community (now: Protocol on the Statute of the Court of Justice of the European Community) done at Brussels on 17 April 1957, (1958) 298 U.N.T.S. 147 [hereinafter Statute (EC)], Article 12, and the corresponding provisions of the Protocol on the Statute of the Court of Justice of the European Atomic Energy Community done at Brussels on 17 April 1957, (1958) 298 U.N.T.S. 256 [hereinafter Statute (EAEC)], and the Statute (ECSC). For the CFI, on the contrary, such assistance is not available.
} 
personal process of decision-making by the judges on the bench. ${ }^{62}$ There seems to be no more room for modifying the operation and procedure of the Court (in order to increase the output) without weakening its unitary voice and legitimacy and without thus compromising its institutional status.

Therefore, the Court of Justice must be relieved of some of its tasks. Supposing that the thresholds for bringing a direct action or making a preliminary reference are not to be raised, ${ }^{63}$ the only possibility to accomplish this relief under the present institutional framework is a transfer of more procedures to the jurisdiction of the CFI. One can say that this, too, would signify a fundamental change. So far, the Community institutions have hesitated to extend the jurisdiction of the CFI beyond the scope envisaged by the Single European Act, although the Maastricht Treaty enabled them to do so. Conferring additional competences on the CFI would lessen the emphasis on fact-finding and change its primary character as an administrative law court and tribunal for staff cases. In any event, the circumstances do not seem to allow allocating more procedures to the CFI while maintaining its present composition. It is already facing an overload of cases, with delays comparable to those in the Court of Justice as a court.

Even if, finally, the CFI were prepared to handle additional cases, the number of appeals to the Court of Justice would inevitably rise. Consequently, the final decision in these proceedings would be delayed by going through an additional instance. ${ }^{64}$ To avoid the accumulation of first instance and appeal proceedings, the right of appeal to the Court of Justice would have to be restricted, thus conferring on the CFI some final jurisdiction in matters of fact and law. After all, this would mean reforming the judicial system structurally and, indeed, to the least extent here argued for.

\footnotetext{
${ }^{62}$ See L. N. Brown \& T. Kennedy, supra n. 37 at 392 , and Court of Justice \& Court of First Instance, Proposals Submitted by the Court of Justice and the Court of First Instance with Regard to the New Intellectual Property Cases (February 1999) <http://curia.eu.int/en/txts/propositions/ index.htm> at $6-7$.

${ }^{63}$ For a discussion of limiting to certain national courts the power to ask the Court of Justice for a preliminary ruling, see Part 3 Section C Subsection III, below.

64 In 1998, 1999 and 2000, the average time taken for appeals to come to decision in the Court of Justice (other than orders terminating a case by removal from register or declaration that the case will not proceed to judgment) amounted to between 19 and 23 months - added on to any delays in the CFI.
} 


\section{Part 3 Identifying possible changes to the judicial}

\section{structure}

Having examined the problems of the Community judicial system as it stands, I now wish to turn to a number of available solutions. Only those approaches will be dealt with that affect the composition of the Community judiciary or redefine its function within a system of national and European courts. Where a development of the procedure is closely linked to any such structural change, it will be considered briefly.

Very few proposals are necessarily part of a complete design for the judicial architecture of the future. It is furthermore contentious whether reform should be brought about radically or in a gradual process. This is a question of the policy of institutional development. However, the evolution of the Community institutions reflects the process of integration, which - as the Treaties foresee - is continuing. ${ }^{1}$ As has been said of the creation of the CFI in the past, ${ }^{2}$ any reform is to mark a step toward the ultimate maturity of the judicial system in the European Union, a goal presumably shared by almost all participants of the debate. ${ }^{3}$

In the following, each approach will be discussed separately. The concluding analysis of the examined proposals, in Part 4, will then lead into the drafting of a model for the judicial structure for the long-term.

\footnotetext{
${ }^{1}$ According to the Preamble of the EC Treaty, the EC is established in order to lay the foundations of an ever closer union among the peoples of Europe', and Article 1 para 2 TEU proclaims a new stage in that process, 'in view of the need of further steps to be taken in order to advance European integration' (Preamble TEU).

${ }^{2}$ See J. L. Da Cruz Vilaça \& L. M. Pais Antunes, "The Court of First Instance of the European Communities: A Significant Step towards the Consolidation of the European Community as a Community Governed by the Rule of Law" (1990) 10 Yearbook of European Law 1 at 4.

${ }^{3}$ It is submitted, however, that the proposals made by the United Kingdom during the intergovernmental conference in 1996 were mainly intended to strengthen the interests of Member State governments and to address some displeasure at the case law of the Court of Justice; see Government of the United Kingdom, A Partnership of Nations: The British Approach to the European Union Intergovernmental Conference 1996 (March 1996), Doc. No. Cm 3181 at para 37, and idem, IGC 1996: Memorandum by the United Kingdom on the European Court of Justice (July 1996). Reports on these documents are given by P. Beaumont, "European Court of Justice and Jurisdiction and Enforcement of Judgments in Civil and Commercial Matters" (1997) 46 International and Comparative Law Quarterly 205 at 208 et seq., and O. Due, "The Impact of the Amsterdam Treaty upon the Court of Justice" (1999) 22 Fordham International Law Journal 48 at 56 et seq.
} 


\section{A. Extending the competences of the court(s) of first instance}

The first approach to be presented here takes up the discussion at the end of the conclusions for the previous part. It goes without saying that a shift of competences away from the Court of Justice as a court would lessen its workload and enable it to concentrate on its core tasks however defined. For the moment, it will be ignored how the judiciary exercising extended competences under the supervision of the Court of Justice should then be structured. Jurisdiction could be given to either the CFI, which would have to be adapted accordingly, or to several courts created by Community law.

\section{Direct actions}

It seems to be widely agreed that, if it does not already exist as a matter of fact, a general jurisdiction for direct actions should be established below the Court of Justice as a court. So far, the Treaties permit only 'certain classes of action or proceeding' to be heard and determined by the CFI. ${ }^{4}$ In the context of the proposed inversion of that principle, the debate concentrates on the types of action to be reserved for the original jurisdiction of the Court of Justice as the European Union's supreme judicial authority.

Some commentators ${ }^{5}$ are not convinced of the necessity for the Court of Justice to retain any jurisdiction at first instance at all in actions for annulment, for failure to act or for damages. According to them, a distinction between actions brought by individuals and undertakings on the one hand and by the Community institutions and the Member States on the other is not compelling. The track record of the CFI is regarded as signifying that jurisdiction in institutional issues may be as satisfactorily exercised by a different court under some kind of supervision by the Court of Justice. ${ }^{6}$ From this viewpoint,

\footnotetext{
${ }^{4}$ See Article 225 (1) and (2) EC Treaty (ex Article 168a (1) and (2) EC Treaty) and Article 140a (1) and (2) EAEC Treaty. Due to its near expiry, provisions of the ECSC Treaty will not be considered in the following.

${ }^{5}$ A. Arnull, "Judicial Architecture or Judicial Folly? The Challenge facing the European Union" (1999) 24 European Law Review 516 [hereinafter "Challenge"] at 518; M. A. Dauses, "Empfiehlt es sich, das System des Rechtsschutzes und der Gerichtsbarkeit in der Europäischen Gemeinschaft weiterzuentwickeln?" (Report for the 60 $0^{\text {th }}$ German Lawyers' Conference, 21 September 1994) in Ständige Deputation des Deutschen Juristentages, ed., Verhandlungen des Sechzigsten Deutschen Juristentags, vol. 1 (München: Beck, 1994) D 1 at D 75; W. van Gerven, "The Role and Structure of the European Judiciary now and in the Future", (1996) 21 European Law Review 211at 218; T. Millett, The Court of First Instance of the European Communities (London: Butterworths, 1990) at $84-85$.

${ }^{6}$ See A. Arnull, "Challenge", supra n. 5 at 518.
} 
proceedings against Member States for failure to fulfil their obligations under the Treaties are to be heard also at the lower level. ${ }^{7}$

The Working Party on the Future of the European Court of Justice, too, has been in favour of a strict principle of assigning the court(s) of first instance to the primary forum for direct actions. ${ }^{8}$ The group considered that the Treaties do not currently permit distinguishing constitutional or quasi-constitutional questions and that in view of the appearance of Community measures, a classification of legislative as opposed to executive forms of action does not hold in general. However, a different distinction has been suggested: some categories of direct actions require a rapid judgment in order to avoid serious obstacles to the functioning of the Community institutions, and they should therefore be settled by the Court of Justice ruling both at first and last instance. ${ }^{9}$ Interestingly, the Working Party contemplated that it is necessary to apply the abovementioned principle in the other cases, since the additional guarantee flowing from two levels of judicial authority 'must benefit the Member States and the Community institutions as much as individuals.'

In contrast, most contributors to the debate argue for the Court of Justice to preserve jurisdiction in all disputes between institutions and, to some extent, in actions by or against Member States as such. ${ }^{11}$ These cases often occupy the Court with questions

\footnotetext{
${ }^{7}$ See especially M. A. Dauses, supra n. 5 at D $76-$ D 79.

${ }^{8}$ See Working Party on the Future of the European Court of Justice, Report by the Working Party on the Future of the European Communities' Court System (Report to the Commission, January 2000) <http://europa.eu.int/comm/igc2000/offdoc/discussiondocs/index_en.htm> at 23-27.

${ }_{9}$ The group proposed to classify infringement proceedings against $\bar{M}$ ember States and those comparable, actions for annulment of decisions taken by the Council in the case of an excessive public deficit, actions for annulment of the authorisation granted by the Council to certain Member States proposing to introduce closer co-operation between themselves, actions for annulment of a Council decisions intended to suspend certain rights of a Member State pursuant to Article 309 (2) and (3) EC Treaty, and actions for annulment of the acts adopting the Community budget, inter alia, as sufficiently urgent and important to be allocated to the Court of Justice.

${ }^{10}$ Working Party on the Future of the European Court of Justice, supra n. 8 at 23.

${ }^{11}$ See Court of First Instance, Reflections on the Future Development of the Community Judicial System (Discussion Paper, 3 December 1990), reprinted (1991) 16 European Law Review 175 [hereinafter "1990 Discussion Paper"] at 182 - 183; European Commission, Reform of the Community Courts (Additional Commission Contribution to the Intergovernmental Conference on Institutional Reform, 1 March 2000) <http://europa.eu.int/comm/igc2000/offdoc/discussiondocs/ cont04022000_en.pdf> at 4; U. Everling, "Empfiehlt es sich, das System des Rechtsschutzes und der Gerichtsbarkeit in der Europäischen Gemeinschaft weiterzuentwickeln?" (Comment for the $60^{\text {th }}$ German Lawyers' Conference, 21 September 1994) in Ständige Deputation des Deutschen Juristentages, ed., Verhandlungen des Sechzigsten Deutschen Juristentags, vol. 2, book 1 (München: Beck, 1994) N 9 [hereinafter "System"] at N 14-N 17; T. Koopmans, "The Future of the Court of Justice of the European Communities" (1991) 11 Yearbook of European Law 15 at 27; C. O. Lenz, "Reform des Europäischen Gerichtshofs im Blick auf die Erweiterung der Europäischen Union" (Forum Constitutionis Europae Lecture 4/00, Humboldt University, Berlin, 8
} 
pertaining to the distribution of powers (between the Community institutions or between the Communities, the European Union and the Member States) and are thus considered institutional or constitutional in character, warranting a rather generous allocation to the highest court of the Union. ${ }^{12}$ Certain areas of law have been identified, however, as giving rise to parallel actions by the Member States and by individuals or undertakings. Such disputes do not as a whole appear constitutional in nature regardless of the standing of the applicant. ${ }^{13}$ Still, they are brought simultaneously before the CFI and the Court of Justice, with only unsatisfactory procedural means to avoid contradictory decisions. The Court of Justice ${ }^{14}$ has therefore requested that jurisdiction be conferred on the CFI in actions brought by Member States so far as they concern Community measures in the fields of: state aid; competition rules applicable to undertakings (especially concerning merger control); protection against imports which are subject to dumping or subsidies; the common transport policy; and the grant of Community financial support by way of funds, financial instruments or action programmes. ${ }^{15}$

It should be noted that the Court regards the request to have been prompted solely by a concern for the proper administration of justice. ${ }^{16}$ Nevertheless, it shows little practical difference to those proposals which take as a point of departure that direct actions should be generally vested in a court of first instance except where the Court of Justice is required to act in its capacity as a 'constitutional court'. In a comprehensive

May 2000) <http://www.whi-berlin.de> at 13; Members of the EC Section of the British Institute's Advisory Board chaired by The Rt. Hon. the Lord Slynn of Hadley, The Role and Future of the European Court of Justice (London: The British Institute of International and Comparative Law, 1996) at 58 - 60; J. L. Da Cruz Vilaça, "La nouvelle Architecture Judiciaire Européene et la Conférence Intergouvernementale" (1996) 32 Cahiers de Droit Européen 3 at 6.

${ }^{12}$ See e.g. C. O. Lenz, supra n. 11 at $14-15$; Members of the EC Section of the British Institute's Advisory Board chaired by The Rt. Hon. the Lord Slynn of Hadley, supra n. 11at 59; J. L. Da Cruz Vilaça, supra n. 11 at 6.

${ }^{13}$ See R. Streinz \& S. Leible, "Die Zukunft des Gerichtssystems der Europäischen Gemeinschaft - Reflexionen über Reflexionspapiere" [2001] Europäisches Wirtschafts- \& Steuerrecht 1 at 11.

${ }^{14}$ Court of Justice, Proposal for Amendment of Council Decision 88/591, with a view to extending the jurisdiction of the Court of First Instance (Proposal submitted to the Council in accordance with former Article 168a EC Treaty, Article 140a EAEC Treaty and Article 32d ECSC Treaty, 27 October 1998) <http://curia.eu.int/en/tsts/propositions/index.htm>.

15 In addition, the Court of Justice proposed a transfer of jurisdiction in actions relating to the clearance of accounts financed by the European Agricultural Guidance and Guarantee Fund, for it considered that such disputes require the appraisal of complex questions of fact, and as an exception the Court called for homogeneity of jurisdiction in all actions based on an arbitration clause so as to assign to the CFI actions brought by natural or legal persons and those brought by Community institutions alike.

${ }^{16}$ See Court of Justice \& Court of First Instance, The Future of the Judicial System of the European Union (Proposals and Reflections) (Discussion Paper, 10 May 1999) <http://curia.eu.int/en/ txt/intergov/ave.pdf> [hereinafter "1999 Discussion Paper"] at 20. 
list, the European Commission has named interinstitutional conflicts as well as actions against legislative instruments of general application and against measures concerning closer co-operation, monetary union, the budget, the title of the EC Treaty on visas, asylum, immigration and other policies related to free movement of persons, the police and judicial co-operation in criminal matters under the TEU, fundamental rights, and the suspension of voting rights of a Member State as pertaining to such a core function. ${ }^{17}$ In that regard, infringement proceedings against the Member States are of varied importance and will be considered later. ${ }^{18}$

\section{Preliminary references}

It is much more controversial whether the competence to give rulings on questions referred by national courts could be shared with, or transferred completely to, one or several courts of first instance.

Some authors ${ }^{19}$ do not see any reason to exclude preliminary references from the jurisdiction at first instance. According to this conception, the Court of Justice would take on the role of a pure court of cassation and constitutional court. ${ }^{20}$ Appeal would lie from rulings on preliminary questions, too, with the Member States and Community institutions having an unrestricted right of appeal. Parties to the proceedings before the national court would also be enabled to lodge an appeal, but in order to prevent a regular prolonging of the preliminary rulings procedure a strict filter would have to be applied. $^{21}$

Others consider the appeal mechanism as generally too time-consuming and also too complex in the context of the system of preliminary references. ${ }^{22}$ It has therefore been contemplated to give the Court of Justice as a court the right to determine, on a case-by-case basis, whether to rule on the question of a domestic court itself or leave

\footnotetext{
${ }^{17}$ See European Commission, supra n. 11 at 4.

${ }^{18}$ See Section E of this part, below.

${ }^{19}$ M. A. Dauses, supra n. 5 at D $84-$ D 85, and U. Everling, "Justiz im Europa von Morgen" [1993] Deutsche Richterzeitung 5 [hereinafter "Justiz"] at 14.

${ }^{20}$ See U. Everling, "System", supra n. 11 at N 16.

${ }^{21}$ See M. A. Dauses, supra n. 5 at D $95-D 98$.

${ }^{22}$ See e.g. Court of Justice, Report on Certain Aspects of the Application of the Treaty on European Union (22 May 1995), reprinted in German [1995] Zeitschrift für Europäisches Gemeinschaftsrecht 316 [hereinafter "1995 Report"] at 318; A. Arnull, "Underpinning the Community's Judicial Architecture" (1997) 22 European Law Review 1 [hereinafter "Architecture"] at 2; V. Lipp, "Entwicklung und Zukunft der Europäischen Gerichtsbarkeit" [1997] Juristenzeitung 326 at 331.
} 
it to the CFI for final decision. ${ }^{23}$ This would require a procedure for delegation or the power of evocation, if preliminary references were to come before the lower court in general. In both cases, the Court of Justice would continue to be occupied with every reference from a national court in order to judge the importance of the question, and thus, the overall workload for the Community judiciary would increase. ${ }^{24}$ Moreover, the idea raises concerns in view of the principle in continental law that the jurisdiction of courts must be determined in advance in abstract and general terms (ius de non evocando; juge légal; gesetzlicher Richter). ${ }^{25}$ It might be said that delegating a case to the CFI is not immediately incompatible with that principle, because the CFI is not a separate institution, but it is attached to the Court of Justice and thus part of it differing not much from the way chambers are. ${ }^{26}$ However, as the Court of Justice and the CFI have two distinct sets of judges, there seems to be a significant difference to the delegation of cases to a chamber composed of members of the same judiciary. This holds true even more, if one agrees with the opinion that the status and function of the CFI (or any other court structure with jurisdiction at first instance at its place) are not appropriately recognised at present by the institutional provisions of the Treaties. ${ }^{27}$

From yet another point of view, preliminary references should be categorised by subject matter or according to the status of the referring court within the domestic legal system so as to share them out between the Court of Justice and the other court(s). ${ }^{28}$ This would establish two separate sets of final jurisdiction in preliminary references. However, the level of domestic jurisdiction from which a question is referred does not in general reflect the significance of the case in the context of Community law and appears

\footnotetext{
${ }^{23}$ See A. Arnull, "Challenge", supra n. 5 at 520; P. J. G. Kapteyn, "The Court of Justice of the European Communities after the Year 2000" in D. Curtin \& T. Heukels, eds., Institutional Dynamics of European Integration - Essays in Honour of Henry G. Schermers, vol. 2 (Dordrecht: Martinus Nijhoff, 1994) 135 at 151; V. Lipp, supra n. 22 at 331; Members of the EC Section of the British Institute's Advisory Board chaired by The Rt. Hon. the Lord Slynn of Hadley, supra n. 11 at $57-58$.

${ }^{24}$ See M. A. Dauses, supra n. 5 at D $83-85$, and Members of the EC Section of the British Institute's Advisory Board chaired by The Rt. Hon. the Lord Slynn of Hadley, supra n. 11 at 58. Giving the CFI an unsupervised discretion whether to rule itself or refer the matter to the Court of Justice would also increase the overall workload and the length of some proceedings and it would compromise the clarity of the tasks assigned to the Court of Justice.

${ }^{25}$ See P. J. G. Kapteyn, supra n. 23 at 151, and Members of the EC Section of the British Institute's Advisory Board chaired by The Rt. Hon. the Lord Slynn of Hadley, supra n. 11 at $57-58$.

${ }^{26}$ See A. Arnull, "Architecture", supra n. 22 at 2, and idem, "Challenge", supra n. 5 at 520.

${ }^{27}$ See e.g. Court of First Instance, Contribution for the Purposes of the 1996 intergovernmental Conference (22 May 1995), reprinted in German [1995] Zeitschrift für Europäisches Gemeinschaftsrecht 320 [hereinafter "1995 Report"] at 322, and J. L. Da Cruz Vilaça, supra n. 11 at 8.

${ }^{28}$ See Court of First Instance," "1990 Discussion Paper", supra n. 11 at $182-183,187$, and C. O. Lenz, supra n. 11 at 13.
} 
to lead to an arbitrary distinction. ${ }^{29}$ Most commentators agree furthermore that it is not feasible on a larger scale to classify subject matters as more or less difficult or more or less important for ensuring uniformity in the interpretation and application of the law. ${ }^{30}$ In view of that obstacle, isolating from each other broad areas of Community law in order to split them among the courts would compromise the main function of the preliminary rulings procedure. Only very few subject matters stand out against the rest by their specialised or highly technical nature, such as the classification under the Common Customs Tariff, the application of the rules on jurisdiction and the enforcement of judgments contained in the former Brussels Convention, and matters referred by the domestic tribunals designated as Community intellectual property courts. With respect to these rather distinguishable categories of cases, some consider it useful to make precisely defined exceptions to the exclusive jurisdiction of the Court of Justice to give preliminary rulings. $^{31}$ But, as the Court of Justice and the CFI have pointed out on various occasions, ${ }^{32}$ such exceptions would have to be accompanied by a mechanism allowing the Court of Justice to act correctively at least in view of subsequent cases. The advantages of transferring some of the jurisdiction in preliminary references are thus confined to references where a contribution of special expertise by a court of first instance outweighs the expenditures of supervision.

In consequence, it is mostly maintained that as a general principle the jurisdiction to rule on preliminary references should be vested in the Court of Justice as a court. ${ }^{33}$ This view is based on the conception that the most important tool for securing the unity

${ }^{29}$ See P. J. G. Kapteyn, supra n. 23 at 151, and A. Arnull, "Challenge", supra n. 5 at 520.

${ }^{30}$ See A. Arnull, "Challenge", supra n. 5 at 520 ; M. A. Dauses, supra n. 5 at D $82-83$; P. J. G. Kapteyn, supra n. 23 at 151; Members of the EC Section of the British Institute's Advisory Board chaired by The Rt. Hon. the Lord Slynn of Hadley, supra n. 11 at 57.

${ }^{31}$ See e.g. Court of Justice \& Court of First Instance, Contribution by the Court of Justice and the Court of First Instance to the Intergovernmental Conference (Contribution to the Intergovernmental Conference on Institutional Reform, February 2000) <http://curia.eu.int/en/txt/intergov/ cig.pdf> [hereinafter "Contribution"] at 4; P. J. G. Kapteyn, supra n. 23 at $150-151$; Members of the EC Section of the British Institute's Advisory Board chaired by The Rt. Hon. the Lord Slynn of Hadley, supra n. 11 at 57 . The Working Party suggested to also consider the jurisdiction in cases of competition law and concerning the police and judicial co-operation in criminal matters and the provisions on visas, asylum and immigration for pooling in the CFI, if certain expected development in these fields of the law would take place; see Working Party on the Future of the European Court of Justice, supra n. 8 at $33-35$.

${ }^{32}$ Court of Justice \& Court of First Instance, "Contribution", supra n. 31 at 4; Court of Justice \& Court of First Instance, "1999 Discussion Paper", supra n. 16 at 26; Court of First Instance, "1990 Discussion Paper", supra n. 11 at $183-184$. See also C. O. Lenz, supra n. 11 at $14-15$.

${ }_{33}$ See Court of Justice, "1995 Report", supra n. 22 at 318; Working Party on the Future of the European Court of Justice, supra n. 8 at 22; W. van Gerven, supra n. 5 at 218; P. J. G. Kapteyn, supra $n .23$ at 151 ; T. Koopmans, supra n. 11 at 27 ; V. Lipp, supra n. 22 at $331 ;$ T. Millett, supra n. 5 at $84-85$. 
and consistency of European Union law is to be assigned to the highest level of the judicial system. ${ }^{34}$ Accordingly, in order 'to avoid the juxtaposition of more than one supreme judicial authority in the Community legal order', ${ }^{35}$ the Court of Justice must retain some kind of supervisory function where it seems favourable for other reasons to allocate even small ranges of preliminary questions to another part of the court system of the Communities.

\section{Standing of individuals to bring actions for annulment}

Another way of increasing the tasks of the court(s) of first instance is to broaden locus standi of natural and legal persons under Article 230 para 4 EC Treaty (ex Article 173 para 4 EC Treaty) and Article 146 para 4 EAEC Treaty. Actions brought under these provisions are currently part of the jurisdiction of the CFI. Contrary to the concern that too generous a standing of individuals will lead to an actio popularis against Community legislation, ${ }^{36}$ many authors argue for lowering the thresholds in order to enable private applicants to take action against any binding Community measure adversely affecting them - regardless of the formal status of the act. ${ }^{37}$ It was stated above ${ }^{38}$ that this point seems particularly strong with regard to cases that call in question the respect for fundamental rights. There is yet an additional advantage: if and in so far as individuals do not depend on the preliminary rulings procedure but are instead to take the avenue of direct action for annulment of Community acts, ${ }^{39}$ the Court of Justice as a court will be effectively relieved of a number of references for preliminary rulings on questions of validity relating to those acts. ${ }^{40}$

\footnotetext{
${ }^{34}$ See e.g. Working Party on the Future of the European Court of Justice, supra n. 8 at 22.

${ }^{35}$ Court of First Instance, "1990 Discussion Paper", supra n. 11 at 176.

${ }^{36}$ See U. Everling, "System", supra n. 11 at N 19, and N. A. E. M. Neuwahl, "Article 173 Paragraph 4 EC: Past, Present, and Possible Future" (1996) 21 European Law Review 17 at 18.

37 See A. Arnull, The European Union and its Court of Justice (Oxford: Oxford University Press, 1999) [hereinafter "Court"] at 49; W. van Gerven, supra n. 5 at 213; Members of the EC Section of the British Institute's Advisory Board chaired by The Rt. Hon. the Lord Slynn of Hadley, supra n. 11 at $93-94$; J. Sedemund, "Empfiehlt es sich, das System des Rechtsschutzes und der Gerichtsbarkeit in der Europäischen Gemeinschaft weiterzuentwickeln?" (Comment for the $60^{\text {th }}$ German Lawyers' Conference, 21 September 1994) in Ständige Deputation des Deutschen Juristentages, supra $\mathrm{n} .11$, at $\mathrm{N} 41$ et seq.

${ }^{38}$ At 37.

${ }^{39}$ In accordance with the present case law of the Court of Justice, preliminary references on the same matter would then be precluded; see Judgment of 9 March 1994, Textilwerke Deggendorf v Germany, C-188/92 [1994] E.C.R. I-833 at I-853.

${ }^{40}$ See Members of the EC Section of the British Institute's Advisory Board chaired by The Rt. Hon. the Lord Slynn of Hadley, supra n. 11 at 94, and L. N. Brown, "National Protection of
} 


\section{Opinions concerning international agreements}

According to Article 300 (6) EC Treaty (ex Article 228 (6) EC Treaty), the Council, the European Commission and the Member States may ask the Court of Justice for an opinion as to whether an international agreement envisaged by the Community is compatible with Community law, in particular in view of the competence to enter into that agreement. ${ }^{41}$ As the opinions are of utmost significance for the development of the Community constitutional order and for the functioning of the Community's participation in international legal activities, it is generally held that this task should not be shifted from the Court of Justice to a court of first instance. ${ }^{42}$ The same applies to a similar procedure under Article 103 (3) EAEC Treaty.

\section{Conclusions}

In contrast to the competence to give preliminary rulings and opinions, one may observe a rather broad understanding that more direct actions should be transferred to the jurisdiction of the CFI or any other structure of courts with jurisdiction at first instance. Currently, however, the docket of the Court of Justice as a court contains only around 40 of these cases per year. Even fewer proceedings would be affected, if the transfer of jurisdiction were confined to actions where the applicants are Member States. ${ }^{43}$ In order to shift more cases from the Court of Justice to the lower court(s) without dividing the jurisdiction in preliminary rulings, it is necessary to give favour to increased direct challenging of Community acts. Such an effect could be achieved by way of broadening the standing of individuals (before the court(s) of first instance) to bring actions for annulment of all forms of Community measures by which they are adversely affected.

At least with any change in the aforementioned direction, it is agreed by many that the CFI or the tribunal replacing it in the future should acquire the status of an

Community Rights: Reconciling Autonomy and Effectiveness" in J. Lonbay \& A. Biondi, eds., Remedies for Breach of EC Law (Chichester: John Wiley \& Sons, 1997) 67 at 67.

${ }^{41}$ See Rules of Procedure (Court of Justice), Article 107 (2).

${ }^{42}$ See M. A. Dauses, supra n. 5 at D 85-86; U. Everling, "System", supra n. 11 at N 15; Working Party on the Future of the European Court of Justice, supra n. 8 at 27.

${ }^{43}$ During the negotiations leading to the conclusion of the Treaty of Nice, for example, the French delegation opposed any changes to the distribution of jurisdiction in direct actions because of modest practical effects, and it rather advocated transferring a proportion of preliminary references to the CFl; see Conference of the Representatives of the Governments of the Member States, IGC 2000: Contribution from the French Delegation on Reform of the Judicial System of the European Union (Information Note, 27 March 2000), Doc. No. CONFER 4726/00 at $7-8$. 
autonomous ordinary court, necessitating an amendment of the treaty provisions on the institutions of the Communities. ${ }^{44}$

Finally, it can be inferred from the discussion that it is not seriously considered to establish any other jurisdiction vested in a court next to the Court of Justice at the top of the judicial hierarchy. The Court of Justice has always had the function to ensure the uniform and consistent application of Community law and to trace the development of the Community legal system, ${ }^{45}$ including where constitutional questions such as the division of power or the compatibility of a measure with rules of a higher order are concerned. ${ }^{46}$ These tasks must be given to a supreme court the singularity of which avoids jurisdictional conflicts and diverging lines of judicial authority. ${ }^{47}$ It seems to be widely held, therefore, that the Court of Justice as a court should preserve its function as single ultimate interpreter of the Community legal order. The Court of Justice may only be relieved of some of its workload by way of shifting proceedings to one or several lower courts under its supervision.

\section{B. Mechanisms for limiting the flow of appeals to the Court of Justice}

In order to avoid congestion in the courts and a general disproportionate prolonging of proceedings, various proposals have been made by which the number of appeals reaching the highest level of the judicial system would be reduced. One will certainly have to think about such mechanisms, if the jurisdiction of the court(s) below the Court of Justice is extended. On the other hand, barring access to the Court of Justice should not be considered wherever the Court continues to exercise jurisdiction at first instance,

\footnotetext{
${ }^{44}$ See European Commission, supra n. 11 at 5, and Working Party on the Future of the European Court of Justice, supra n. 8 at 36 . See also text accompanying note 27, above.

${ }^{45}$ See especially Court of Justice \& Court of First Instance, "1999 Discussion Paper", supra n. 16 at 8; H. G. Schermers \& D. F. Waelbroeck, Judicial Protection in the European Communities, $5^{\text {th }}$ ed. (Deventer: Kluwer, 1992) at $§ 876$; J. L. Da Cruz Vilaça \& L. M. Pais Antunes, supra n. 2 at $55 ;$ J. H. H. Weiler, "The European Court, National Courts and References for Preliminary Rulings - The Paradox of Success: A Revisionist View of Article 177 EEC" (EUI Working Paper 85/203) in EUI Working Papers (Badia Fiesolana: European University Institute, 1985) at 5.

${ }^{46}$ See Court of Justice \& Court of First Instance, "1999 Discussion Paper", supra n. 16 at 8, and J. L. Da Cruz Vilaça, supra n. 11 at 5-6. See also A. M. Donner, "The Constitutional Powers of the Court of Justice of the European Communities", (1974) 11 Common Market Law Review 127. ${ }^{47}$ See Court of First Instance, "1990 Discussion Paper", supra n. 11 at $176-177$; P. J. G. Kapteyn, supra n. 23 at 146; T. Koopmans, supra n. 11 at 32; V. Lipp, supra n. 22 at 331; Members of the EC Section of the British Institute's Advisory Board chaired by The Rt. Hon. the Lord Slynn of Hadley, supra n. 11 at 56; J. L. Da Cruz Vilaça, supra n. 11 at 6; Working Party on the Future of the European Court of Justice, supra n. 8 at 22.
} 
for this could lead to a denial of justice. ${ }^{48}$ Filters to be applied to preliminary questions directly referred from the national courts will be examined later. ${ }^{49}$ The discussion thus focuses on how the Court of Justice could fulfil a supervisory function regarding the decisions of the court(s) of first instance without overstretching both its own capacities and the resources of the parties who seek a final settlement in their dispute.

\section{Leave to appeal and selection}

Many contributors to the debate ${ }^{50}$ are in favour of introducing restrictions on the right of appeal, in particular where proceedings have to be commenced before judicial or quasijudicial organs before the matter may be heard by a court of first instance. ${ }^{51}$ This is currently required for actions against decisions of the OHIM and the CPVO, with the Boards of Appeal of these agencies providing an independent review of the decision prior to any proceedings before the $\mathrm{CFI}$.

As to the test of whether the right of appeal should be given, the least farreaching restriction would be a summary mechanism for rejecting clearly inadmissible or clearly unfounded appeals. In fact, the Rules of Procedure already allow the Court of Justice to rule on appeals of this kind by reasoned order, acting on a report from the judge rapporteur and after hearing the advocate general. ${ }^{52}$ This possibility is used frequently. ${ }^{53}$ On the grounds that the CFI may be considered deciding at second instance where the case has already been heard by a judicial or quasi-judicial organ, the Court of Justice has now proposed the use of filters applied by it in a preliminary proce-

\footnotetext{
${ }^{48}$ See e.g. Members of the EC Section of the British Institute's Advisory Board chaired by The Rt. Hon. the Lord Slynn of Hadley, supra $n .11$ at 117.

${ }^{49}$ See Section C Subsection IV of this part, below.

${ }^{50}$ See Court of Justice \& Court of First Instance, "1999 Discussion Paper", supra n. 16 at 15; European Commission, supra n. 11 at 5; A. Arnull, "Challenge", supra n. 5 at 518; M. A. Dauses, supra n. 5 at D $89-93$; U. Everling, "System", supra n. 11 at N 16; Working Party on the Future of the European Court of Justice, supra n. 8 at $28-29$. Contra C. O. Lenz, supra n. 11 at $13-$ 14 , and Members of the EC Section of the British Institute's Advisory Board chaired by The Rt. Hon. the Lord Slynn of Hadley, supra n. 11 at $118-119$.

${ }^{51}$ See especially Court of Justice \& Court of First Instance, "Contribution", supra n. 31 at 3 , and Court of Justice \& Court of First Instance, Proposals Submitted by the Court of Justice and the Court of First Instance with Regard to the New intellectual Property Cases (February 1999) $<$ http://curia.eu.int/en/txts/propositions/index.htm> [hereinafter "Proposals Intellectual Property Cases"] at 9.

${ }^{52}$ See Article 119 of the Rules of Procedure (Court of Justice).

${ }^{53}$ See Members of the EC Section of the British Institute's Advisory Board chaired by The Rt. Hon. the Lord Slynn of Hadley, supra n. 11 at 60.
} 
dure to determine 'the expediency' of appeal against a particular judgment of the CFI. ${ }^{54}$ Upon request, the Court of Justice as a court would decide on granting or denying leave without oral proceedings. According to the proposal, the categories of cases requiring leave to appeal would be laid down in the Statutes of the Court of Justice by way of unanimous vote of the Council. ${ }^{55}$

Others suggest a general filtering of appeals so as to subject every appeal against a decision of a court of first instance to an initial assessment by the Court of Justice. The following filtering criteria have been contemplated inter alia: ${ }^{56}$ significance of the case for the development of the Community legal order or significance for the solution of a general point of law going beyond the circumstances of that case, and also risk of divergence in the case law of the Court of Justice and that of a lower court or in the decisions of separate chambers or separate courts with jurisdiction at first instance. Again, this reflects that the function of ensuring the uniform and consistent application of Community law and tracing the evolution of the law in principled cases is ultimately attributed to the Court of Justice as a court.

Applying filtering criteria such as those mentioned above may be in the form of an admissibility-test the conditions of which are laid down in the relevant legislation or case law - or it may be at the discretion of the court to select the appeals it will hear. ${ }^{57}$ To draw a comparison, the Supreme Court of the United States and the Supreme Court of Canada both have a power of selection of the second type, except in a rather narrow range of cases where there is an appeal as of right. Access to the Supreme Court of the United States almost always depends on the grant of a writ of certiorari, which is not a matter of right, but of judicial discretion. ${ }^{58}$ The Court may thus deny certiorari for reasons of judicial policy, and as a matter of principle it does not formulate the reasons for a denial. ${ }^{59}$ In Canada, the primary function of the Supreme Court is to hear appeals

${ }^{54}$ See Court of Justice \& Court of First Instance, "Proposals Intellectual Property Cases", supra n. 51 at 9, and Court of Justice \& Court of First Instance, "1999 Discussion Paper", supra n. 16 at 15.

${ }^{55}$ See Court of Justice \& Court of First Instance, "Contribution", supra n. 31 at 3.

${ }^{56}$ See A. Arnull, "Challenge", supra n. 5 at 518; M. A. Dauses, supra n. 5 at D 90; U. Everling, "System", supra n. 11 at $\mathrm{N} \mathrm{16;} \mathrm{Working} \mathrm{Party} \mathrm{on} \mathrm{the} \mathrm{Future} \mathrm{of} \mathrm{the} \mathrm{European} \mathrm{Court} \mathrm{of} \mathrm{Justice,}$ supra n. 8 at 28 .

${ }^{57}$ See Members of the EC Section of the British Institute's Advisory Board chaired by The Rt. Hon. the Lord Slynn of Hadley, supra n. 11 at $114-116$, and M. A. Dauses, supra n. 5 at D $88-$ 90.

${ }^{58}$ Rules of the Supreme Court of the United States adopted 26 July 1995, [2001] U.S.C.S. Court Rules - Supreme Court, Rule 10.

${ }^{59}$ See G. R. Stone et al., Constitutional Law, $4^{\text {th }}$ ed. (Gaithersburg: Aspen Law \& Business, 2001) at $135-136$. 
from both provincial and federal courts of appeal. ${ }^{60}$ In most cases, the Court has the power to decide whether to grant leave, and it does so according to the 'public importance' of the questions involved, or for any other perceived necessity for the particular case to be decided at the highest level of the judicial system. ${ }^{61}$ Here, too, the considerations of the Court are not reflected in a body of case law, as it does not give reasons for the grant or denial of leave to appeal. ${ }^{62}$

\section{Appeals brought by Member States or Community institutions}

Some authors arguing for the general initial filtering of appeals specify that there should be an appeal as of right for institutional applicants and the Member States, especially in conjunction with a complete or partial transfer of direct actions to the jurisdiction of the court(s) of first instance. ${ }^{63}$ According to the Statutes of the Court of Justice, the Community institutions and the Member States currently have standing to bring appeals even where they are neither party to the dispute nor have intervened in the proceedings before the $\mathrm{CFI}{ }^{64}$

It is submitted that preserving this privilege would not harmonise well with a limitation on appeals to the Court of Justice in other cases, as influential private parties, to give just one example, might urge the governments of their countries to lodge an appeal on their behalf. So far as the unrestricted appeal as of right is based on the idea that the Community institutions and the Member States may act as additional guardians of the evolution of Community law, ${ }^{65}$ the system might be replaced by a generally applicable pourvoi dans lintérêt de la loi. Recourse in the interest of the law does not prevent judgments from becoming final nor does it affect them later on, but it may re-establish the unity and consistent interpretation of the law in future cases. ${ }^{66}$ The Court of Justice as a court would thus be enabled to concentrate on its main task performed without delaying any proceedings the parties to which have not chosen to appeal or have not

\footnotetext{
${ }^{60}$ As an exception, the Supreme Court of Canada has jurisdiction to rule on questions directly referred to it by the federal government; see Supreme Court Act, formerly Supreme and Exchequer Courts Act, 1875, now R.S.C. 1985 c. S-26, Section 53.

${ }^{61}$ See ibid., Section 40 (1).

62 See P. W. Hogg, Constitutional Law of Canada, $4^{\text {th }}$ ed. (loose-leaf) (Scarborough: Carswell, 1997) at 8-12 and 8-13.

63 See M. A. Dauses, supra n. 5 at D 90, and U. Everling, "System", supra n. 11 at N 16.

${ }^{64}$ Article 49 para 3 of the Statute (EC) and Article 50 para 3 of the Statute (EAEC).

${ }^{65}$ See U. Everling, "System", supra n. 11 at N 16.

${ }^{66}$ See C. O. Lenz, supra n. 11 at 12, and K. Borgsmidt, "The Advocate General at the European Court of Justice: A Comparative Study" (1988) 13 European Law Review 106 at 113
} 
been granted leave. It has been proposed that only the Commission ${ }^{67}$ or only the advocates general at the Court of Justice ${ }^{68}$ may propose a review in the interest of the law in order to limit the power of instituting the procedure according to its exceptional nature.

Similarly, it does not seem justified to maintain an unconditioned standing of Community institutions and Member States to appeal decisions affecting them as a party or as an intervener to a case. If all direct actions by or against these parties were to be brought before the court(s) of first instance, leave to appeal could be guaranteed in appropriate cases by adding to the filtering criteria that of constitutional significance. ${ }^{69}$ The Member States and the Community institutions would thus benefit from an additional special basis for granting leave to appeal, but only in so far as they would be affected by a decision as constitutional agents as such. The same privilege could apply after their having intervened in the proceedings before a court of first instance.

Limited direct access of Member States and institutional applicants to the Court of Justice as a court and the subjecting of their appeals to the test whether the issues at stake are of constitutional nature (where not fulfilling another criterion) would signify a specialisation of the Court of Justice in that regard. From this perspective, if it were for the Court of Justice to select from the requests for leave to appeal the cases or parts of cases comprising constitutional issues, the system would have sufficient flexibility, indeed, to permit a specialisation of this kind (in addition, for example, to the task of ensuring the unity of the law). ${ }^{70}$ The obstacle of defining constitutional matters in abstract has often been named as prohibiting a specialisation and a more general division of jurisdiction between the Court of Justice and the court(s) of first instance in direct actions. $^{71}$ It is submitted that the precise distinction of cases of constitutional importance, whether by selection or in abstract, will become more feasible as soon as the European Union is set to reorganise the Treaties so as to extract a Basic Treaty, which would contain the fundamental rules of European Union law, or formulate a constitutional

\footnotetext{
${ }^{67}$ See Working Party on the Future of the European Court of Justice, supra n. 8 at 37.

${ }^{68}$ See C. O. Lenz, supra n. 11 at $16-17$.

${ }^{69}$ See generally Members of the EC Section of the British Institute's Advisory Board chaired by The Rt. Hon. the Lord Slynn of Hadley, supra n. 11 at 115.

${ }^{70}$ In favour of an explicit specialisation of the Court of Justice as 'constitutional court': Court of First Instance, "1990 Discussion Paper", supra n. 11 at 181; A. Bzdera, "L'Enjeu Politique de la Réforme Institutionelle de la Cour de Justice de la Communauté Européene" (1992) 356 Revue du Marché Commun et de I"Union Européene 240 at 249; U. Everling, "Justiz", supra n. 19 at 13; C. O. Lenz, supra n. 11 at $14-15$; R. Streinz \& S. Leible, supra n. 13 at $11-12$.

${ }^{71}$ See P. J. G. Kapteyn, supra n. 23 at $147-148$; V. Lipp, supra n. 22 at 332 ; J. L. Da Cruz Vilaça, supra n. 11 at $5-6$; Working Party on the Future of the European Court of Justice, supra n. 8 at 24 . See also Section A Subsection I of this part, above.
} 
text. This project is now under examination by the Convention on the Future of the European Union summoned by the European Council. ${ }^{72}$ The Convention is composed of representatives of the European Parliament, the European Commission and the governments and national parliaments of the Member States and the accession candidate countries. ${ }^{73}$ It has held its inaugural meeting on 28 February 2002 and is expected to draw up a final report within a period of one year.

\section{Protection of fundamental rights}

It can be inferred from the above discussion that the filtering of appeals will primarily bar natural and legal persons from access to the Court of Justice as a court. Therefore, if the introduction of double judicial control has strengthened the judicial protection of individual interests, ${ }^{74}$ one may say that restricting the right of appeal translates into diminishing that protection. This might be balanced by a certain design of the system of courts below the Court of Justice. The protection of fundamental rights, however, is appropriately part of the function of the Court of Justice as the supreme court of the Community legal order. ${ }^{75}$ Thus, the significance of a case in the light of the respect for fundamental rights should be considered another criterion for granting leave to appeal. ${ }^{76}$ This would especially harmonise with including the Charter of Fundamental Rights ${ }^{77}$ in the envisaged Basic Treaty or constitutional text, a possibility the Convention on the Future of the European Union has been asked to examine. ${ }^{78}$

\footnotetext{
${ }^{72}$ See European Council, Laeken Declaration on the future of the European Union adopted on 14 and 15 December 2001, Doc. No. SN 300/01 ADD 1 at 2 et seq. The initiative is connected to the encouragement of a deeper and wider debate about the future of the European Union as called for in Declaration (No. 23) on the future of the Union adopted by the Conference of the Representatives of the Governments of the Member States, Final Act of Nice done on 26 February 2001, [2001] O.J. C 80/70 at $85-86$.

${ }^{33}$ The European Council has appointed Valerie Giscard d'Estaing, former President of France, as chairman of the Convention.

${ }^{74}$ See J. L. Da Cruz Vilaça \& L. M. Pais Antunes, supra n. 2 at 54 ; see also Council Decision 88/591/ECSC, EEC, Euratom of 24 October 1988 establishing a Court of First Instance of the European Communities, [1988] O.J. L $319 / 1$ and [1989] O.J. L 241/4 (corrigenda), $14^{\text {th }}$ Recital.

${ }^{75}$ See generally Court of First Instance, "1990 Discussion Paper", supra n. 11 at 182 - 183; European Commission, supra n. 11 at $4-5 ;$ J. L. Da Cruz Vilaça \& L. M. Pais Antunes, supra n. 2 at 55.

${ }^{76}$ See U. Everling, "System", supra n. 11 at N 16, and Working Party on the Future of the European Court of Justice, supra n. 8 at 28.

17 Charter of Fundamental Rights of the European Union solemnly proclaimed by the European Parliament, the Council and the European Commission, Nice, 7 December 2000, [2000] O.J. C $364 / 1$.

${ }^{78}$ See European Council, Laeken Declaration on the future of the European Union adopted on 14 and 15 December 2001, supra n. 72 at 7.
} 
In the form of an appeal, access to the Court of Justice as a court on grounds of an alleged infringement of fundamental rights would depend on the full exhaustion of other remedies. The responsibility for the protection of human rights should continue to be shared by all Community courts. The tendency that 'applicants dress up cases as involving fundamental rights in order to take advantage of the more generous standing rules $^{79}$ would have to be forestalled by a strict and transparent application of the conditions for granting leave - or if this proved an insufficient barrier, by a more flexible filtering mechanism following the model of the certiorari jurisdiction of the Supreme Court of the United States or the system of selection exercised by the Supreme Court of Canada.

A reform along these lines is close to establishing a special direct recourse to the Court of Justice for breach of fundamental rights as known in the Verfassungsbeschwerde before the German Bundesverfassungsgericht and in similar procedures of the constitutional courts of Austria, Italy, Portugal and Spain. ${ }^{80}$ It would seem that the mechanism could thus be extended to all measures of the European Union (including those currently adopted under the third pillar) and to legislative, administrative and, not least, judicial decisions of the Member States taken in implementation of European Union law. The latter extension, however, would lead to an excessively high number of proceedings before the Court of Justice even if the exhaustion of domestic remedies were required. The Court of Justice would risk being hailed as ultimate court of cassation, contrary to the system of co-operation, and also to the national courts' own responsibility for the protection of human rights. Therefore, it seems preferable, on the one hand, to increase the judicial protection of individual interests by broadening locus standi of natural and legal persons in proceedings before the court(s) of first instance followed by the opportunity to seek leave to appeal on the basis of an alleged infringement of fundamental rights, and on the other, to preserve for the domestic courts the review of national implementing acts in conjunction with the courts' competence - and sometimes obligation - to ask the Court of Justice for a preliminary ruling.

\footnotetext{
${ }^{79}$ This is anticipated as a consequence of an amendment to Article 230 para 4 EC Treaty that would take possible infringements of fundamental rights into account, see A. Arnull, "Court", supra n. 37 at 49 .

${ }^{80}$ See M. A. Dauses, supra n. 5 at D $139-140$. Introduction of a corresponding recourse to the Court of Justice is proposed by J. L. Da Cruz Vilaça, supra n. 11 at 5, and R. Voß, "Empfiehlt es sich, das System des Rechtsschutzes und der Gerichtsbarkeit in der Europäischen Gemeinschaft weiterzuentwickeln?" (Comment for the $60^{\text {th }}$ German Lawyers' Conference, 21 September 1994) in Ständige Deputation des Deutschen Juristentages, supra n. 11, N 25 at N 27; see also W. van Gerven, supra n. 5 at 213, and U. Everling, "System", supra n. 11 at N 19.
} 
Finally, a reform of the rules on the standing and the right of appeal of individuals may serve to clarify the relationship between the Community court system and the enforcement mechanism applying to the protection of human rights under the ECHR. Neither the Communities nor the Member States in their collectiveness as European Union are party to the ECHR. Moreover, so far as the Treaties confer on the Court of Justice the competence to exercise judicial review, the Community judicial system is recognised for its control of the respect for fundamental rights. Applications to the European Court of Human Rights are thus held inadmissible when implicating one of the Communities or when directed at a Member State executing Community acts, as far as the measures concerned are subject to review or guidance by the Court of Justice. ${ }^{81}$ Clarification seems useful, however, with regard to activities under the provisions of the police and judicial co-operation in criminal matters (Title VI of the TEU) and to Commum nity measures which although in the form of a normative act are binding on, and adversely affect, particular individuals. On the other hand, establishing a link between the judicial system of the Communities and the European Court of Human Rights would require accession to the ECHR the merits of which cannot be discussed here. ${ }^{82}$ However, it is suggested here that for the sake of effective judicial protection, the European Union will have to continue to provide for appropriate recourse to its supreme court where the respect for fundamental rights is seriously called in question, regardless of whether it submits to the jurisdiction of the European Court of Human Rights.

\section{Appeals against preliminary rulings}

It is conceivable that certain filtering criteria would also be applicable in appeals against decisions in preliminary references, if the competence to give these rulings were trans-

${ }^{81}$ See European Commission of Human Rights, Decision of 10 July 1978, CFDT $\vee$ European Communities and Others, Application No. 8030/77, 13 D.R. 231 at 240, and Decision of 9 February 1990, M. \& Co. v Germany, Application No. 13258/87, 64 D.R. 138 at $144-146$.

82 Upon request for an opinion under Article 228 (6) EC Treaty (now Article 300 (6) EC Treaty), the Court of Justice has held that the Community currently lacks the competence to accede to the ECHR; see Opinion of 28 March 1996, Accession by the Community to the European Convention for the Protection of Human Rights and Fundamental Freedoms, Opinion 2/94 [1996] E.C.R. I1759 at $1-1789$. In general, however, the Community's capacity 'to conclude international agreements necessarily entails the power to submit to the decisions of a court which is created or designated by such an agreement as regards the interpretation and application of its provisions'; see Court of Justice, Opinion of 14 December 1991, Draft agreement between the Community, on the one hand, and the countries of the European Free Trade Association, on the other, relating to the creation of the European Economic Area, Opinion 1/91 [1991] E.C.R. I-6079 at 1-6106. A debate on the accession by the Communities to the ECHR has now been put on the agenda of the Convention on the Future of the European Union; see European Council, Laeken Declaration on the future of the European Union adopted on 14 and 15 December 2001, supra n. 72 at 7. 
ferred partly or in total to one or several courts of first instance. However, it will be recalled that most commentators disapprove of an appeal mechanism inserted in the preliminary reference procedure. It might be preferable, therefore, to establish a pourvoi dans l'intérêt de la loi for preliminary rulings given by a court of first instance. ${ }^{83}$ Here, again, the procedure would enable the Court of Justice to ensure uniformity and consistency in the interpretation of Community law and to oversee the development of fundamental legal principles without overburdening the proceedings in the present case. It is submitted, however, that the potential drawbacks for the administration of justice would be justified only on an exceptional basis and in the context of an overall gain in judicial protection, following for instance from the general acceleration of decisions in urgent matters or the provision of special expertise in particular cases.

\section{Increasing the responsibility of the courts of the Member States}

This section will deal with different proposals according to which national courts would assume more responsibilities as forums for matters of Community law. Most reflections on the future of the preliminary rulings procedure centre on this idea. It is obvious that the more independently domestic courts proceed in the interpretation and application of the Community legal order, the more the Community judiciary will be relieved of this task by way of preliminary references in particular cases. The debate is thus really about the future design of the system of co-operation.

In contrast, it appears that there are no suggestions for giving national courts jurisdiction in matters currently settled by any of the other procedures under the Treaties. $^{84}$ Disputes of institutional or constitutional nature are naturally part of the exclusive jurisdiction of the courts belonging to the institutional framework at stake. The same applies to all procedures in which the Court of Justice or the CFI take on the role of ordi-

\footnotetext{
${ }^{83}$ See C. O. Lenz, supra n. 11 at 13 , and Working Party on the Future of the European Court of Justice, supra n. 8 at 37 . In its own contribution to the intergovernmental conference in 2000 , the Court of Justice has not specified the review procedure it considered 'necessary in order to safeguard the unity and coherence of Community law', if jurisdiction in preliminary references is conferred on a court of first instance, see Court of Justice \& Court of First Instance, "Contribution", supra n. 31 at 4.

${ }^{84}$ As an exception, it has been proposed to allow the European Commission to bring actions for failure to comply to Community law directly before the courts of the Member States concerned; see J. P. Jacqué \& J. H.H. Weiler, "On the road to European Union - A new Judicial Architecture: An Agenda for the Intergovernmental Conference" (1990) 27 Common Market Law Review 185. This will be discussed together with other proposals concerning infringement proceedings against Member States in Section $E$ of this part, below.
} 
nary courts vis-à-vis the execution of the law by institutions of the Communities: in the light of the principle of strict division of competence, the national court systems cannot be sufficiently harmonised in order to provide equal and coherent judicial protection against administrative Community measures in all the Member States, and to preserve the unitary character of such measures. ${ }^{85}$ It would seem that the decentralised jurisdiction in disputes over Community intellectual property rights constitutes an example to the contrary. But this is an exception. The power to invalidate Community trade marks and Community designs is vested in some domestic courts as a solution for the inseparability of the question of validity from the matters of private law which these courts are to decide. It was noted above ${ }^{86}$ that similar solutions have already proven unacceptable for the envisaged unitary patent system.

\section{Encouraging independence}

The first proposition is directed at the national courts' attitude towards ruling on the application of Community law themselves. Some contributors to the debate ${ }^{87}$ are in favour of clarifying the treaty provisions on preliminary references so as to reaffirm that it is for the domestic courts in the first place to apply Community law to the legal disputes before them and that the function of the Court of Justice is confined to offering assistance in appropriate cases. ${ }^{88}$ Moreover, the use of discretion whether to consult the Court of Justice could be encouraged in courts other than those of last resort by introducing criteria for the assessment of the advisability of asking for a preliminary ruling. ${ }^{89}$ With regard to references failing to meet such conditions, the Court of Justice could also simply go over to give general judgments recalling the principles and rules of interpretation developed in previous cases and leaving it to the referring court to rule on the

\footnotetext{
${ }^{85}$ See V. Lipp, supra n. 22 at 330 . See also Members of the EC Section of the British Institute's Advisory Board chaired by The Rt. Hon. the Lord Slynn of Hadley, supra n. 11 at $110-113$.

${ }^{86}$ At 24.

${ }^{87}$ See European Commission, supra n. 11 at 3; R. Streinz \& S. Leible, supra n. 13 at 10; Working Party on the Future of the European Court of Justice, supra n. 8 at 14.

${ }^{88}$ Clarity would then require incorporating a provision according to which all national courts must refer to the Court of Justice when doubting the validity of a Community act; see European Commission, supra n. 11 at 4, and Working Party on the Future of the European Court of Justice, supra n. 8 at 14

${ }_{89}$ The Working Party on the Future of the European Court of Justice, supra n. 8 at $14-15$, has suggested the combination of the following two criteria: significance of the question in terms of Community law and reasonable doubt about the answer.
} 
particular matter, possibly after a declaration of self-restraint by the Court. ${ }^{90}$ In this context, the Rules of Procedure have recently been amended to permit the Court of Justice giving its decision by reasoned order, where a question from a national court is identical to a question on which the Court has already ruled, where the answer to such a question may be clearly deduced from existing case law or where the answer to the question admits of no reasonable doubt'. ${ }^{91}$ Finally, as the Court of Justice has done before, ${ }^{92}$ it may exert some influence on the future operation of the system of co-operation by issuing information notes addressed to the courts of the Member States.

It is to be recalled here that most domestic courts have discretion whether to ask for a preliminary ruling under the Treaties, and that they do make use of it already. ${ }^{93}$ In the light of a perceived need for further encouragement, the main question is how to address the national courts without running too great a risk of affecting their willingness to consult the Court of Justice in appropriate cases. ${ }^{94}$ The necessary prediction is difficult to make, but the question itself argues for a cautious and organic approach when it comes to changes to the system of co-operation. ${ }^{95}$

Encouraging lower courts to solve problems of Community law for themselves also raises the question whether national courts of last resort should continue to be obliged to refer all matters to the Court of Justice or whether this obligation should be confined to questions where it would have been appropriate for a lower court to make a reference for a preliminary ruling. ${ }^{96}$ The danger is obvious: the courts of last instance some of which have struggled to accept the supreme authority of the Court of Justice may misunderstand, if not strain, the limits to their duties. ${ }^{97}$ According to one proposal, ${ }^{98}$

\footnotetext{
${ }^{90}$ See the Opinion of Advocate General Francis G. Jacobs delivered on 10 July 1997, Court of Justice (Judgment of 20 November 1997), Wiener S/ v Hauptzollamt Emmerich, C-338/95 [1997] E.C.R. 1-6495 at $1-6502-1-6503$.

${ }_{91}$ See Amendments to the Rules of Procedure of the Court of Justice of 16 May 2000, [2000] 0.J. $L 122 / 43$, Article $1(6)$ amending Article 104 (3) of the Rules of Procedure (Court of Justice).

${ }^{92}$ See Court of Justice, Information Note on References by National Courts for Preliminary Rulings (9 December 1996) <http://curia.eu.int/en/txts/others/index.htm>.

${ }^{93}$ See S. E. Strasser, "Evolution and Effort: Docket Control and Preliminary References in the European Court of Justice" (1996) 2 Columbia Journal of European Law 49 at 73.

${ }_{94}$ See A. Arnull, "Challenge", supra n. 5 at 521 , and R. Streinz \& S. Leible, supra n. 13 at $10-11$.

${ }^{95}$ See generally P. J. G. Kapteyn, supra n. 23 at 150, and J. H. H. Weiler, supra n. 45 at 19.

${ }^{96}$ In support of partly or completely abolishing the obligation of the national courts of last resort: F. G. Jacobs in his Opinion delivered in the case Wiener SI v Hauptzollamt Emmerich, supra $n$. 90 at 1-6513; Working Party on the Future of the European Court of Justice, supra n. 8 at 15; A. Arnull, "Challenge", supra n. 5 at 521. Contra European Commission, supra n. 11 at 4; Members of the EC Section of the British Institute's Advisory Board chaired by The Rt. Hon. the Lord Slynn of Hadley, supra n. 11 at 76 ; J. H. H. Weiler, supra n. 45 at $22-23$.

${ }^{97}$ See A. Arnull, "Challenge", supra n. 5 at 521.
} 
this could be sufficiently remedied by instituting infringement proceedings against the Member States concerned, or by way of a pourvoi dans l'intérêt de la loi to be inserted in the Treaties in order to restore the unity of the law wherever the system of co-operation has failed. To this it is submitted that preserving the current functioning of co-operation seems to be a more worthwhile task. Therefore, so far as the courts of the Member States are indeed to be encouraged to more independence, it should be for the Court of Justice to do so by using its case law and other flexible means by way of which it has significantly shaped the spirit of co-operation in the first place.

\section{Submission of draft answers to the question referred}

It has been contemplated to introduce a summary procedure for preliminary references containing a reasoned draft reply in order for the Court of Justice to state that there is no objection to the interpretation proposed ('green light procedure'). ${ }^{99}$ This idea is based on the assumption that the courts of the Member States, encouraged by the benefit of shorter delays in the disputes before them, would become more involved in the application and the development of Community law, if it were for them to formulate replies to their questions. However, it seems to be agreed that no obligation of such kind should be imposed on the referring courts, as it might discourage references from judges who are less experienced with matters of Community law and, as concerns the courts of last instance, deteriorate compliance to the obligation to refer in the first place. ${ }^{100}$

In so far as the submission of a draft answer and reasoning is considered helpful for the clarity of the reference and for the domestic court's closer examination of the relevance of the question, it might be more efficient to address this directly. By way of case law and further informal recommendations the Court could set out additional guidelines as to the background information included in preliminary references. ${ }^{101}$ Moreover, recent amendments to the Rule of Procedure enable the Court of Justice to request

\footnotetext{
${ }^{98}$ See Working Party on the Future of the European Court of Justice, supra n. 8 at 16.

${ }^{99}$ See especially J. H. H. Weiler, supra n. 45 at $19-22$, and S. E. Strasser, supra n. 93 at $87-$ 88.

${ }^{100}$ See M. A. Dauses, supra n. 5 at D 131; U. Everling, "System", supra n. 11 at N 13-14; S. E. Strasser, supra n. 93 at 88 . See also Members of the EC Section of the British Institute's Advisory Board chaired by The Rt. Hon. the Lord Slynn of Hadley, supra n. 11 at 82, and Working Party on the Future of the European Court of Justice, supra n. 8 at 18.

${ }^{101}$ Some standardisation of preliminary references is suggested by S. E. Strasser, supra $\mathrm{n} .93$ at $86-87$, and Working Party on the Future of the European Court of Justice, supra n. 8 at 17.
} 
clarification from the referring tribunal. ${ }^{102}$ Finally, if accelerated procedures are to remain an exception in order to safeguard the authority of the body of preliminary rulings, the Court of Justice should remain as flexible as possible in applying provisions which simplify the proceedings before it. ${ }^{103}$ Where suggestions from national courts appear advantageous in general, it should be left to the Court of Justice, thus again, to innovate and strengthen the co-operation between courts by its familiar means.

\section{Limiting the courts entitled to make preliminary references}

In the attempt to reserve the preliminary rulings procedure for important and wellprepared cases, the power to refer questions to the Court of Justice could be confined to the national courts of last resort or at least to those ruling at the appellate level. Proponents of this idea claim that it would streamline the handling of preliminary references by the courts of the Member States and that the Community legal system would then appropriately reflect the unifying tasks and powers which the higher or highest domestic courts assume under national law. ${ }^{104}$ Others are not convinced. ${ }^{105}$ They attach utmost importance to the preliminary rulings system as the means of ensuring the uniform interpretation and application of Community law and as a vehicle for the Court of Justice to contribute to a consistent development of the Community legal order. ${ }^{106}$ From this perspective, questions arising in proceedings before inferior domestic courts and those encountered by the courts of higher instance seem to be at least equally important, and

\footnotetext{
${ }^{102}$ See Amendments to the Rules of Procedure of the Court of Justice of 16 May 2000, supra $\mathrm{n}$. 91. Article 1 (8) inserting a new text as Paragraph 5 in Article 104 of the Rules of Procedure (Court of Justice).

${ }^{103}$ The Rules of Procedure (Court of Justice) now permit dispensing with the oral hearing and using an expedited procedure, upon request of the referring court, for references of exceptional urgency; see Articles 104 (4) and 104a of the Rules of Procedure (Court of Justice) as amended by Amendments to the Rules of Procedure of the Court of Justice of 16 May 2000, supra n. 91, Article 1 (7) and (9).

${ }^{104}$ See V. Lipp, supra n. 22 at $331-332$, and S. E. Strasser, supra n. 93 at $76-77$.

105 See Court of Justice \& Court of First Instance, "1999 Discussion Paper", supra n. 16 at $22-$ 23; Working Party on the Future of the European Court of Justice, supra n. 8 at $12-13$; A. Arnull, "Challenge", supra n. 5 at 519; L. N. Brown \& T. Kennedy, L. N. Brown and F. G. Jacobs' The Court of Justice of the European Communities, $5^{\text {th }}$ ed. (London: Sweet \& Maxwell, 2000) at $394-$ 395; M. A. Dauses, supra n. 5 at D 121 - 123; U. Everling, "System", supra n. 11 at N 14; R. Streinz \& S. Leible, supra n. 13 at 10;

${ }^{106}$ See e.g. Court of Justice, "1995 Report", supra n. 22 at 318, and Working Party on the Future of the European Court of Justice, supra n. 8 at 12.
} 
so is the participation of all the respective judges in the dialogue with the Court of Justice. ${ }^{107}$

Opting for an exclusion of some or all of the lower courts from the preliminary reference procedure might be based on the perception that the Community legal order now comprises a firm body of law contained in books, reports and databases, and that it is increasingly part of the legal education in the Member States. However, the acquaintance with Community law, and the function that the referring of questions to the Court of Justice may have in this respect for the formation of national courts, differ widely between the judicial systems of the Member States. ${ }^{108}$ This will be reinforced by the envisaged large number of accessions to the European Union in the near future, and there is no reason to assume that the courts of the acceding countries would benefit to a lesser extent from the support by the Court of Justice than the other judiciaries have done (and still do) when accustoming themselves to the effects of Community law. ${ }^{109}$ It seems, therefore, that to deprive a group of courts of the power to ask the Court of Justice for preliminary rulings is too crude a mechanism for strengthening the responsibility of the domestic courts in the foreseeable time.

Finally, if limitations were to apply, individual litigants would have to bring appeals up to a certain level in order to gain access to the Court of Justice by way of a preliminary reference. In view of the necessary exclusive power of the Community courts to hold acts of the Communities illegal, this would compromise the judicial protection of individuals, ${ }^{110}$ although the effects might be significantly mitigated by broadening the standing of natural and legal persons to bring direct actions against such acts. And even if it was only for seeking favourable interpretations by the Court of Justice, the requirement of bringing appeals could be detrimental to procedural economy in the national court systems. ${ }^{111}$ The major drawback, however, seems to follow from the severe

${ }^{107}$ See A. Arnull, "Court", supra n. 37 at $49-50$; L. N. Brown \& T. Kennedy, supra n. 105 at 395; M. A. Dauses, supra n. 5 at D $122-123$; O. Due, supra n. 3 at $63-64$.

${ }^{108}$ See especially J. H. H. Weiler, supra n. 45 at $10-12$, and S. E. Strasser, supra n. 93 at $84-$ 85.

${ }^{109}$ See Working Party on the Future of the European Court of Justice, supra n. 8 at 12.

${ }^{110}$ See M. A. Dauses, supra n. 5 at D 121 and 123, and L. N. Brown \& T. Kennedy, supra n. 105 at 395 ; for an early analysis of preliminary references as a system affording individuals the necessary judicial protection, see the Opinion of Advocate General Karl J. Roemer delivered on 16 December 1963, Court of Justice (Judgment of 18 February 1964), Crediet- en Handelsvereiniging Rotterdam and Suikerfabriek en Raffinaderij Puttershoek $v$ Minister van Landbouw en Visserij, Cases 73 and 74/63 [1964] E.C.R. 1 at 22.

${ }^{111}$ See Court of Justice \& Court of First Instance, "1999 Discussion Paper", supra n. 16 at 23, and Working Party on the Future of the European Court of Justice, supra n. 8 at 13. 
discouragement of litigants initiating judicial review of the compatibility of a Member State's behaviour with the rules of Community law: the more restricted the path to a preliminary ruling is the less interpretative support is given to domestic courts and, in consequence, to individuals whose 'vigilance...to protect their rights amounts to an effective supervision in addition to the supervision entrusted by Article 169 and 170 [now Articles 226 and 227 EC Treaty] to the diligence of the Commission and of the Member States. $^{112}$

\section{Selection of questions by the Court of Justice}

Another way of reducing the load of cases to be terminated by preliminary rulings is to give the Court of Justice the power to assess the expediency of dealing with questions referred to it and to select those it wishes to answer. This would be a flexible instrument to shift responsibility to the national courts, and it would enable the Court of Justice to focus on matters which it considers sufficiently important from the perspective of the unity and development of Community law. However, such a variation on the certiorari jurisdiction or the system of granting leave to appeal according to the public importance of the case seems to be disapproved of almost unanimously. ${ }^{113}$

As a major technical obstacle, the refusal of the Court of Justice to take a case would not simply mean that the decision of the referring court remained final (as is for instance the effect of 'certiorari denied'), but it would leave that court without support for establishing the law of the case in the first place. ${ }^{114}$ Secondly, so far as national courts have discretion to make a preliminary reference, a selection has already occurred at that level, entailing a more or less significant amount of work for determining the expediency of a reference and for preparing the case for the Court of Justice. ${ }^{115}$ To interfere in this selection would be out of keeping with the proper appraisal of the function of the refer-

\footnotetext{
112 Court of Justice, Judgment of 5 February 1963, Van Gend en Loos v Nederlandse Administratie der Belastingen, Case 26/62 [1963] E.C.R. 1 at 13.

${ }^{113}$ See Court of Justice \& Court of First Instance, "1999 Discussion Paper", supra n. 16 at 23 25; A. Arnull, "Challenge", supra n. 5 at 519; L. N. Brown, supra n. 40 at 70 ; M. A. Dauses, supra n. 5 at D $93-95$; U. Everling, "System", supra n. 11 at N $12-N 13$; T. Koopmans, supra n. 11 at $29-30$; V. Lipp, supra n. 22 at 332; Members of the EC Section of the British Institute's Advisory Board chaired by The Rt. Hon. the Lord Slynn of Hadley, supra n. 11 at $117-119 ; \mathrm{S}$. E. Strasser, supra n. 93 at $77-78$; Working Party on the Future of the European Court of Justice, supra n. 8 at 21.

${ }_{114}$ See T. Koopmans, supra n. 11 at 29, and M. A. Dauses, supra n. 5 at D 94 (annotation 238).

115 See Members of the EC Section of the British institute's Advisory Board chaired by The Rt. Hon. the Lord Slynn of Hadley, supra n. 11 at $117-118$.
} 
ring court. ${ }^{116}$ On the contrary, the possibility of a question being refused for lack of importance is expected to deter domestic courts, in upsetting the mutual co-operation, from asking for preliminary rulings in general. ${ }^{117}$ References might thus fail to arrive even where it is be clearly appropriate to involve the Court of Justice. Lastly, a selective mechanism is considered undesirable in view of an ongoing formation of the Community legal order following from changes in the membership of the European Union and in the constitutional system. ${ }^{118}$ In this light, the significance of a preliminary reference for the development of Community law seems difficult to assess at first sight, or it may simply be advantageous to rely on the selection from the point of view of the national proceedings, compelling the Court of Justice to deal with any questions referred to it upon discretion or by one of the highest courts of the Member States. ${ }^{119}$ This point seems especially strong given the general difficulty in identifying the real implication of a particular reference from a domestic court in matters of Community law as opposed to factual issues and those of national law. ${ }^{120}$

In order to avoid the abovementioned obstacles, the preliminary reference procedure could be transformed into an appeal mechanism, enabling the Court of Justice to make its selection of cases in knowledge of the complete context of the judgments given by the national courts and conscious of the effects of the interpretations of Community law adopted therein. ${ }^{121}$ The national courts would thus have full responsibility for applying and interpreting Community law by themselves, subject to review by the Court of Justice. This, however, would abolish judicial co-operation altogether and replace it with

\footnotetext{
${ }^{116}$ As the Court of Justice has expressed in Judgment of 1 December 1965, Schwarze v. Einfuhrund Vorratsstelle für Getreide und Futtermittel, Case 16/65 [1965] E.C.R. 877 at 886 (emphasis added):
}

[T] he special field of cooperation under Article 177 [now Article 234 EC Treaty]...requires the national court and the Court of Justice, both keeping within their respective jurisdiction, and with the aim of ensuring that Community law is applied in a unified manner, to make direct and complementary contributions to the working out of a decision.

117 See e.g. Working Party on the Future of the European Court of Justice, supra n. 8 at 21 ; Members of the EC Section of the British Institute's Advisory Board chaired by The Rt. Hon. the Lord Slynn of Hadley, supra n. 11 at 118; A. Arnull, "Challenge", supra n. 5 at 519.

${ }_{118}$ See T. Koopmans, supra n. 11 at 30 , and S. E. Strasser, supra n. 93 at 78.

${ }_{119}^{11}$ See especially T. Koopmans, supra $n .11$ at 30.

120 See D. Edward, "How the Court of Justice Works" (1995) 20 European Law Review 539 at 545.

${ }^{121}$ See C. Harlow, "A Common European Law of Remedies?" in C. Kilpatrick, T. Novitz \& P. Skidmore, eds., The Future of Remedies in Europe (Oxford: Hart, 2000) 69 at $82-83$, and Court of Justice \& Court of First Instance, "1999 Discussion Paper", supra n. 16 at 24. 
a decidedly hierarchical system. ${ }^{122}$ It is in line with arguments stated throughout this thesis to assume that the co-operative element in the relations between the domestic courts and the Court of Justice, currently functioning well on the basis of mutual respect and confidence, should be preserved in essence. It has extraordinarily contributed to the uniformity, coherence and effectiveness of the Community legal order and can be expected to continue to succeed in doing so.

\section{Designation of decentralised judicial bodies with limited jurisdiction to rule on preliminary references}

A different fundamental change to the existing system would be brought about by setting up judicial bodies in each Member State that would specialise in Community law and deal with preliminary references from the courts of that State. ${ }^{123}$ Such bodies would have to decide, according to the importance of the matter, whether to rule on the questions referred or make yet another reference to the Court of Justice - or they would have jurisdiction to give a ruling in every case, subject to the power of the Court of Justice to review the decision on appeal or in a procedure in the interest of the law. Decentralisation of this kind would have the advantage of the preliminary reference system getting closer to the Member States' legal orders, the domestic courts and the citizens, ${ }^{124}$ and that enormous savings in time and money would follow from the possibility to leave out the translation of documents in the first round of the procedure. ${ }^{125}$

However, the objections raised in general against a two-step procedure for preliminary references would apply. ${ }^{126}$ The same holds true with respect to the suggestion that each question from a national court could be assessed as to its significance at the outset: the Court of Justice would be occupied with every reference in order to determine whether to re-delegate or in order to exercise the power of evocation, thus diminishing the striven-for relief in its workload ${ }^{127}$ and requiring once again full translation

\footnotetext{
${ }^{122}$ See Court of Justice \& Court of First Instance, "1999 Discussion Paper", supra n. 16 at 25, and Working Party on the Future of the European Court of Justice, supra n. 8 at 13-14.

${ }^{123}$ See Court of Justice \& Court of First Instance, "1999 Discussion Paper", supra n. 16 at 26 27 , and Working Party on the Future of the European Court of Justice, supra n. 8 at $20-21$.

${ }_{124}$ See e.g. P. J. G. Kapteyn, supra n. 23 at 148, and Members of the EC Section of the British Institute's Advisory Board chaired by The Rt. Hon. the Lord Slynn of Hadley, supra n. 11 at 102, assuming the same advantages for regional courts having jurisdiction with regard to a limited number of Member States.

${ }^{125}$ See Court of Justice \& Court of First Instance, "1999 Discussion Paper", supra n. 16 at 26, and Working Party on the Future of the European Court of Justice, supra n. 8 at 20.

${ }_{126}$ See the discussion at 45 and 58 , above.

${ }^{127}$ See Working Party on the Future of the European Court of Justice, supra n. 8 at 21.
} 
of the court file. ${ }^{128}$ Yet, the primary objection against transferring some of the jurisdiction in preliminary references to national judicial bodies is that it would put at risk the uniform interpretation and application of Community law and run counter to the consistent development of the legal order that the system is intended to bring about. ${ }^{129}$

Fewer drawbacks have been attributed to the creation of decentralised courts forming part of the Community court structure. ${ }^{130}$ It is to be pointed out that this would not have the effect of redistributing judicial competences between the Member States and the European Union, which has been the subject of this section so far. According to the proposal by Jacqué and Weiler, a number of regional courts would have jurisdiction, among other tasks, to rule on preliminary references from national courts within each territorial area, subject to a right of appeal to the Court of Justice. ${ }^{131}$ Every regional Community court would be composed of judges from the Member States covered by its jurisdiction and from a selection of other Member States. ${ }^{132}$

Most commentators, however, consider the Community legal order as too vulnerable to sustain decentralising the major instrument of ensuring its unity even in the long term. ${ }^{133}$ By comparison with federal states which might gain from a structure of regional federal law courts, the law of the Member States taken as a whole consists of much more diverse legal systems. Both the operability of preliminary rulings in every legal

${ }^{128}$ It is questionable whether the judicial institutions can be relieved of the translation burden by structural reforms in general: leaving aside the political dimension of the principle of linguistic equality, it is considered necessary for the effectiveness and legitimacy of any jurisprudence of Community-wide significance (including the opinions of the advocates general) that it is available in all official languages - at least so if it does not merely repeat the existing case law; see e.g. A. Arnull, "Challenge", supra n. 5 at $522-523$, and Working Party on the Future of the European Court of Justice, supra n. 8 at 45 . This would equally apply to judicial bodies within the national court structure whose decisions in preliminary references would sometimes become final. Furthermore, the necessary monitoring of the proceedings before such national bodies, whether by the Court of Justice, the Community institutions, the Member States and their courts, or the European public, would at some point require translation of the essential documents into one or several 'working languages'. It is proposed here to look at the multilingualism of the European Union as a feature of cultural diversity that calls for appropriate technical and financial support rather than institutional changes; see generally $D$. Edward, supra $n .120$ at $545-547$, and $R$. Streinz \& S. Leible, supra n. 13 at 10.

${ }^{129}$ See Court of Justice \& Court of First Instance, "1999 Discussion Paper", supra n. 16 at 26; A. Arnull, "Challenge", supra n. 5 at $519-520$; C. O. Lenz, supra n. 11 at 12; R. Streinz \& S. Leible, supra n. 13 at 5; Working Party on the Future of the European Court of Justice, supra n. 8 at 21.

${ }_{131}^{130}$ See J.P. Jacqué \& J. H.H. Weiler, supra n. 84 at $196-197$.

${ }^{131}$ See J.P. Jacqué \& J. H.H. Weiler, supra n. 84 at $192-193$.

${ }^{132}$ See J. P. Jacqué \& J. H.H. Weiler, supran. 84 at 194.

${ }^{133}$ See Court of Justice \& Court of First Instance, "1999 Discussion Paper", supra n. 16 at 26; M. A. Dauses, supra n. 5 at D 100; U. Everling, "Justiz", supra n. 19 at 13; P. J. G. Kapteyn, supra n. 23 at $148-149$; V. Lipp, supra n. 22 at 331; Members of the EC Section of the British Institute's Advisory Board chaired by The Rt. Hon. the Lord Slynn of Hadley, supra n. 11 at $103-104$; R. Streinz \& S. Leible, supra n. 13 at 5. 
system and their successful contribution to the development of Community law are said to derive from the presence of all the different legal backgrounds on the bench - or at least from their pooling in a single judicial institution. ${ }^{134}$ In this context, the assumed advantage that regional courts would acquire special expertise as concerns the legal systems within their territorial jurisdiction ${ }^{135}$ appears to turn into quite the opposite. It follows that it is undesirable to divide by regions the power to rule on questions concerning the interpretation and validity of Community law, and so is in general any intrusion in the direct interaction between the domestic courts (the ordinary Community law courts) and the Community court which, single by principle, is entrusted with safeguarding the unity of the law and tracing the development of the Community legal order.

\section{Institutionalising chambers; creation of specialised tribunals}

The representation of varied legal traditions in the Community judiciary leads to the discussion of the use of chambers and other divisions formally constituted and to the question whether to promote the specialisation of such divisions or of separate judicial bodies with jurisdiction at first instance in particular fields of Community law.

\section{Court divisions and the principle of representation}

It seems to be widely agreed, not just for reasons of political feasibility, that the membership of the Court of Justice at the top of the Community court structure should continue to reflect the whole variety of national legal orders comprised by the European Union. ${ }^{136}$ Full representation is usually regarded as ensuring that major developments in Community law are informed by the riches of the different traditions ${ }^{137}$ and that the most impor-

${ }^{134}$ See especially U. Everling, “Justiz”, supra n. 19 at 13; P. J. G. Kapteyn, supra n. 23 at 148 $149 ;$ R. Streinz \& S. Leible, supra n. 13 at 5.

${ }^{135}$ See J.P. Jacqué \& J. H.H. Weiler, supra n. 84 at 197.

${ }^{136}$ See A. Arnull, "Challenge", supra n. 5 at 522; U. Everling, "System", supra n. 11 at N 17; C. O. Lenz, supra n. 11 at 18; V. Lipp, supra n. 22 at 331; Members of the EC Section of the British Institute's Advisory Board chaired by The Rt. Hon. the Lord Slynn of Hadley, supra n. 11 at 44 46; R. Streinz \& S. Leible, supra n. 13 at $4-5$; Working Party on the Future of the European Court of Justice, supra n. 8 at 46 . For a statement on an early understanding by the Member States to this effect during the intergovernmental conference in 2000 , see Conference of the Representatives of the Governments of the Member States, Intergovernmental Conference on Institutional Reform (Report to the Feira European Council, 14 June 2000), Doc. No. CONFER 4750/00 at 40 .

${ }^{137}$ See Court of First Instance, "1990 Discussion Paper", supra n. 11 at 177; Working Party on the Future of the European Court of Justice, supra n. 8 at 46; U. Everling, "The Court of Justice as a Decisionmaking Authority" (1984) 82 Michigan Law Review 1294 at 1295 - 1296; V. Lipp, 
tant judicial decisions benefit from the Court's expertise in all the legal systems (and widest linguistic skills) and are thus comprehensible and applicable in every Member State. ${ }^{138}$ This may foster compliance by national courts and enhance the general acceptance of the jurisprudence of the Court of Justice. ${ }^{139}$

In order to preserve the workability and quality of judicial decision-making, it appears necessary, then, to further restrict the use of the complete plenum, as a substantial enlargement of the Court of Justice as a court will follow from the envisaged accessions of new Member States. Some commentators ${ }^{140}$ suggest fully developing the system of chambers of three or five judges. According to this idea, a chamber would have a fairly constant membership and jurisdiction in a number of predetermined fields of the law. The Court of Justice would sit in plenary session only when it decides to do so for maintaining the unity of its case law. The formalised constitution of the Court's chambers would have the advantage of respecting some of the aforementioned conceptions of the need for transparency and certainty in the allocation of cases to a particular judge. ${ }^{141}$ But the principle of representation would be mostly lost. ${ }^{142}$

In view of that objection, others propose institutionalising a form of the so-called petit plenum. $^{143}$ The petit plenum is currently based on the quorum of nine judges for decisions of the full Court, ${ }^{144}$ with two additional judges sitting to allow for subsequent absences. ${ }^{145}$ It is considered a successful mechanism of balancing the use of chambers and plenary sessions and of providing a cross section of the views represented in the judiciary. ${ }^{146}$ If, according to the proposals, the number of judges in the plenum were

supra n. 22 at 331; Members of the EC Section of the British Institute's Advisory Board chaired by The Rt. Hon. the Lord Slynn of Hadley, supra n. 11 at 103.

${ }^{138}$ See especially D. Edward, supra n. 120 at 548 and 553; H. G. Schermers \& D. Waelbroeck, supra $\mathrm{n} .45$ at $\S 773$; Members of the EC Section of the British Institute's Advisory Board chaired by The Rt. Hon. the Lord Slynn of Hadley, supra n. 11 at $45-46$.

139 See Court of Justice, "1995 Report", supra n. 22 at 319; C. O. Lenz, supra n. 11 at 18; R. Streinz \& S. Leible, supra n. 13 at 5; Working Party on the Future of the European Court of Justice, supra n. 8 at 46.

${ }^{140}$ R. Streinz \& S. Leible, supra n. 13 at $6-7$; M. A. Dauses, supra n. 5 at D $101-104$; C. O. Lenz, supra $\mathrm{n} .11$ at $18-19$.

${ }^{141}$ See the discussion at 46 , above. See also M. A. Dauses, supra n. 5 at D $103-104$, and W. van Gerven, supra n. 5 at 222.

${ }^{142}$ See R. Streinz \& S. Leible, supran. 13 at 7.

${ }^{143}$ See Working Party on the Future of the European Court of Justice, supra n. 8 at $46-47$, and A. Arnull, "Challenge", supra n. 5 at 522

${ }_{145}$ See Article 15 of the Statute (EC) and the corresponding provisions of the Statute (EAEC).

${ }^{145}$ See D. Edward, supra n. 120 at 542.

${ }^{146}$ See Members of the EC Section of the British Institute's Advisory Board chaired by The Rt. Hon. the Lord Slynn of Hadley, supra n. 11 at $49-50$, and D. Edward, supra n. 120 at 542. 
generally limited to thirteen, plenary formations could eventually sit more frequently. ${ }^{147}$ The composition of such formations could either follow a certain scheme to be determined on a case-by-case basis, or stay fixed for a limited period of time. It has been suggested to enable a grand plenum to be called upon exceptionally in order to forestall inconsistencies in the case law of different plenary formations. ${ }^{148}$

In the debate about the future composition of the CFI, in contrast, the nationalities of the judges are hardly an issue. If the CFI (or any other structure of courts at its place) is given an enhanced function, the rising workload will require an increase in size following which there will be at least as many posts for judges as there are Member States in any case. ${ }^{149}$ Furthermore, the number of chambers may be raised without posing the risk of fragmentation, as long as the Court of Justice as a court continues to ensure the coherence of the case law, ${ }^{150}$ whether by way of its appellate jurisdiction or through other mechanisms such as a pourvoi dans l'intérêt de la loi or an interlocutory procedure for questions referred to it by the court(s) of first instance. ${ }^{151}$ From this perspective, the composition of the lower courts may be determined solely by the requirements of an effective administration of justice in the cases before them ${ }^{152}$ and regardless of the (equal) representation of nationalities. ${ }^{153}$

\section{Specialisation}

Institutionalising chambers or other divisions of the CFI may serve another development: in order to gain from some rationalization and from gathering expertise in ever more

${ }^{147}$ See A. Arnull, "Challenge", supra n. 5 at 522, and L. N. Brown \& T. Kennedy, supra n. 105 at 389

148 See A. Arnull, "Challenge", supra n. 5 at 522 . This system is known in the German Bundesverfassungsgericht sitting in two separate formations of permanent composition, the socalled 'senates'; see R. Streinz \& S. Leible, supra n. 13 at 6 (annotation 41).

149 The Court of Justice and the CFI have already requested to increase the number of members of the latter with respect to the expected influx of cases concerning Community intellectual property rights, and they suggest that the same will be necessary in general, if the competences of the CFI are extended. See Court of First Instance, "1995 Report", supra n. 27 at $321-322$; Court of Justice \& Court of First Instance, "1999 Discussion Paper", supra n. 16 at 25; Court of Justice \& Court of First Instance, "Proposals Intellectual Property Cases", supra n. 51 at 6-7.

${ }_{150}$ See A. Arnull, "Refurbishing the Judicial Architecture of the European Community" (1994) 43 International and Comparative Law Quaterly 296 at 313 - 314, and Members of the EC Section of the British Institute's Advisory Board chaired by The Rt. Hon. the Lord Slynn of Hadley, supra n. 11 at $46-47$.

151 For a proposition of the latter, see Court of Justice, "1995 Report", supra n. 22 at 319.

152 As an example, amendments to the Rules of Procedure (CFI) have recently introduced the possibility to assign or delegate cases to a single judge; see Amendments to the Rules of Procedure of the Court of First Instance of the European Communities to enable it to give decisions in cases when constituted by a single judge of 17 May 1999, [1999] O.J. L 135/92.

${ }^{153}$ See European Commission, supra n. 11 at 8, and J. L. Da Cruz Vilaça, supra n. 11 at 7. 
technical and complex fields of the law, chambers formally constituted could specialise in particular categories of disputes ${ }^{154}$ or even form separate specialised divisions within the one court. ${ }^{155}$ Customs law, anti-dumping, state aids, competition law, Community intellectual property rights, staff cases and those concerning the common agricultural policy, and also social security, taxation, environmental law, company law, product responsibility, private international law and the rules on jurisdiction and the recognition and enforcement of judgements have all been named as likely fields of specialisation of one or several chambers of the CFI. ${ }^{156}$ The latter categories, of course, would require that the $\mathrm{CFI}$ be given jurisdiction to rule on preliminary references concerning these more or less specialist fields of the law. ${ }^{157}$

Having come thus far, it is also conceivable to divide off some areas of jurisdiction in order to confer them on specialised courts of first instance, with the CFI remaining the Community court of first instance of general jurisdiction. ${ }^{158}$ The evolution of the twotier structure of Court of Justice and CFI has always been the mark of a desired Community patent system, ${ }^{159}$ and as a model, the CFI itself was in practice initially a court specialised in staff and competition cases and in actions brought by steel and coal producers. However, an extension of the notion of establishing other courts of first instance at the level of the CFI beyond jurisdiction in disputes over intellectual property law is highly contentious. ${ }^{160}$ Leaving aside budgetary restraints, the primary objection is that

\footnotetext{
${ }^{154}$ See especially Court of Justice, "1995 Report", supra n. 22 at 319; Court of First Instance, “1995 Report", supra n. 27 at 321; U. Everling, "System”, supra n. 11 at N $16-17$; J. L. Da Cruz Vilaça, supra n. 11 at 7.

${ }^{155}$ A structure following the divisions in the English High Court is proposed by D. W. J. Scorey, "A new Model for the Communities' Judicial Architecture in the new Union" (1996) 21 European Law Review 224 at $229-230$.

${ }^{156}$ See U. Everling, “Justiz”, supra n. 19 at 14 (annotation 64); C. O. Lenz, supra n. 11 at 13; Members of the EC Section of the British Institute's Advisory Board chaired by The Rt. Hon. the Lord Slynn of Hadley, supra n. 11 at 50.

${ }^{157}$ Conferring the jurisdiction to rule on certain preliminary references and appeals to expert chambers formally constituted within the Court of Justice as a court is proposed by M. A. Dauses, supra n. 5 at D $102-103$, and W. van Gerven, supra n. 5 at $221-222$; contra e.g. U. Everling, "System", supra n. 11 at N 17, and Members of the EC Section of the British Institute's Advisory Board chaired by The Rt. Hon. the Lord Slynn of Hadley, supra n. 11 at 50 . The Working Party on the Future of the European Court of Justice, on the other hand, contemplates withdrawing preliminary references concerning the judicial co-operation in civil matters from the Court of Justice and assigning them to a separate specialised Community court composed of judges with a background in private international law; see Working Party on the Future of the European Court of Justice, supra n. 8 at $32-33$.

${ }^{158}$ See especially W. van Gerven, supra n. 5 at 218 , and M. A. Dauses, supra n. 5 at D $98-99$.

${ }^{159}$ See the discussion at $24-25$, above.

160 In contrast to the Court of Justice, the CFI has always opposed the creation of other courts next to itself, except where Community intellectual property rights were concerned; see Court of
} 
the co-ordination of the case law is much more difficult between several judicial institutions than within a single court allowing not only for plenary sessions but also for informal communication between the judges. ${ }^{161}$ This is based on the idea that the more homogenous the jurisprudence is at first instance, the less it will be for the Court of Justice as a court to resolve conflicts, with obvious gains for the efficient distribution of justice in particular cases. Also, the organisation of specialised divisions within a court, even if formally constituted, seems to be more flexible than a structure of several courts of first instance. ${ }^{162}$ Some authors, finally, consider that the fields of specialisation should rotate among the judges from time to time ${ }^{163}$ which would be hampered by a system of separate courts.

\section{Tribunals below the Court of First Instance}

Another approach to specialisation to be considered here is the creation of separate judicial bodies from whose decisions at first instance appeal would lie to the CFI. ${ }^{164}$ The CFI could thus be relieved of categories of easily identifiable cases emanating from legal orders which stand out as specialised and less interwoven with other areas of Community law. ${ }^{165}$ The new bodies would have the nature of law courts, and the right of appeal against their decisions would be confined to points of law only. Two models for this development are found, for instance, in the Tax Courts of the United States and of Canada both of which have replaced administrative boards within the federal executive branch. ${ }^{166}$

A specialised tribunal of first instance seems to be of immediate use for the handling of staff cases. Not only do matters relating to Community staff constantly

First Instance, "1990 Discussion Paper", supra n. 11 at $179-181$, and Court of First Instance, "1995 Report", supra n. 27 at 321.

${ }^{161}$ See Members of the EC Section of the British Institute's Advisory Board chaired by The Rt. Hon. the Lord Slynn of Hadley, supra n. 11 at $108-109$; M. A. Dauses, supra n. 5 at D 100; U. Everling, "Justiz", supra n. 19 at 14 . See also T. Koopmans, supra n. 11 at $28-29$.

162 See M. A. Dauses, supra n. 5 at D 100, and V. Lipp, supra n. 22 at 330.

${ }^{163}$ See P. J. G. Kapteyn, supra n. 23 at 149; Members of the EC Section of the British Institute's Advisory Board chaired by The Rt. Hon. the Lord Slynn of Hadley, supra n. 11 at 109 . See also Working Party on the Future of the European Court of Justice, supra n. 8 at $49-50$.

${ }^{164}$ For this proposition, see Court of Justice \& Court of First Instance, "Contribution", supra n. 31 at $4-5$; European Commission, supra n. 11 at $6-7$; C. O. Lenz, supra n. 11 at $13-14$; Working Party on the Future of the European Court of Justice, supra n. 8 at $29-32$.

${ }^{165}$ See Working Party on the Future of the European Court of Justice, supra n. 8 at 36, and European Commission, supra n. 11 at $6-7$.

${ }_{166}$ See Tax Court of Canada Act, 1983, now R.S.C. 1985 c. T-2, and R. H. Fallon, D. J. Meltzer \& D. L. Shapiro, Hart and Wechsler's The Federal Courts and the Federal System, $4^{\text {th }}$ ed. (Westbury: The Foundation Press, 1996) at 44. 
account for one-forth to one-third of the proceedings before the $\mathrm{CFI}_{3}{ }^{167}$ but they also require detailed investigation as to the facts of the dispute. ${ }^{168}$ Furthermore, the composition of a separate staff tribunal would differ from that of a chamber of the CFI and enable it to exercise a special conciliatory function. ${ }^{169}$ Another natural field of application appears to be the jurisdiction in actions against decision of the OHIM and the CPVO. Along with changes to the jurisdiction in staff cases, it has been proposed separating the Boards of Appeal of the OHIM from the agency's institutional structure and transforming them into a special tribunal for actions concerning the grant and validity of Community trade marks and Community designs. ${ }^{170}$ A similar system is conceivable to replace the Boards of Appeal of the CPVO, and it could be institutionally merged with the trade mark and design tribunal.

However, it is difficult to imagine advancing further towards a two-tier structure below the Court of Justice as a court. ${ }^{171}$ Apart from staff cases and actions against separate administrative agencies, classifying the nature of proceedings, say, in actions brought by individuals against the European Commission, seems not feasible and also difficult to justify, if that determines whether the CFI has jurisdiction at first or second instance. The disadvantages of separate specialist courts are all the more applicable where jurisdictions compete on different levels of the judicial hierarchy, for example: inflexibility in the allotment of categories of cases; added complexity; and obstacles for the rotation of judges. In its present formations, furthermore, the CFI might not be able to perform the task of preserving the coherence of the case law originating in several courts below. If the Court of Justice were thus to retain that function in full, it would often have to step in at third instance or upon an application in the interest of the law. This would either mean further delaying the proceedings or compromising the distribution of justice in individual cases. ${ }^{172}$ On the other hand, there seem to be no good reasons for restructuring the $\mathrm{CFI}$ so as to enable it to act as the guardian of the unity of the law in

\footnotetext{
167 These are the ratios for the years 1998 to 2000 .

${ }^{168}$ See Members of the EC Section of the British Institute's Advisory Board chaired by The Rt. Hon. the Lord Slynn of Hadley, supra n. 11 at 109.

${ }^{169}$ See Court of Justice \& Court of First Instance, "1999 Discussion Paper", supra n. 16 at 16, and Working Party on the Future of the European Court of Justice, supra n. 8 at $30-31$.

${ }^{170}$ See European Commission, supra n. 11 at $6-7$, and Working Party on the Future of the European Court of Justice, supra n. 8 at 31.

${ }_{171}$ See generally W. van Gerven, supra n. 5 at 218.

172 Interestingly, so far as the abovementioned proposals deal with the general introduction of special tribunals below the $\mathrm{CFI}$, they remain rather vague regarding limitations on further appeals to the Court of Justice as a court; see Court of Justice \& Court of First Instance, "Contribution", supra n. 31 at $4-5$, and European Commission, supra n. 11 at 7.
} 
general, when the Court of Justice as a court is well prepared to fulfil this task. ${ }^{173}$ Therefore, any general improvements in expertise and capacity are to be sought for by enlarging the CFI as a single unitary court of first instance and institutionalising the use of its chambers or divisions.

\section{Decentralisation}

The objections raised against a general scheme of separating different courts of first instance, whether at the level of the CFI or within a three-tiered structure, apply also to the idea of establishing regional Community courts. According to a proposal that was discussed above ${ }^{174}$ with respect to preliminary references, regional Community courts would take over, among other competences, the function currently exercised by the CFI. ${ }^{175}$ Jurisdiction at first instance would be geographically divided among them, and from their decisions appeal would lie to the Court of Justice. ${ }^{176}$ The decision of whether or not to hear a particular appeal would be at the discretion of that court. One may say that this would closely follow the structure of the twelve circuits of the United States Courts of Appeals (formerly 'circuit courts') ${ }^{177}$ whose decisions may be reviewed on petition for certiorari by the Supreme Court of the United States.

Most commentators, however, are not convinced. ${ }^{178}$ Leaving aside the expenses of full infrastructure in several cities, ${ }^{179}$ the principal drawback is seen in the loss of interaction between all the legal systems and thus of the opportunity to forestall disharmonies and diverging lines of judicial authority as early as possible in the procedures

${ }^{173}$ In analogy, the idea of establishing a second tier of judges in the Court of Justice, with an internal appeal lying from decisions of the lower tier to the higher formation, does not offer a compelling alternative to the extension of the jurisdiction of the CFI in conjunction with an increase in the number of judges of that court. For a discussion, see Members of the EC Section of the British Institute's Advisory Board chaired by The Rt. Hon. the Lord Slynn of Hadley, supra n. 11 at $104-106 ;$ O. Due, supran. 3 at 58; P. Beaumont, supra n. 3 at 210.

${ }^{174}$ At $67-68$.

${ }^{175}$ See J.P. Jacqué \& J. H.H. Weiler, supra n. 84 at $192-195$.

${ }^{176}$ According to the proposal by Jacqué and Weiler, the court at the apex of the system would be renamed 'European High Court of Justice'; see ibid. at 192.

177 See United States Code Title 28 Section 41, originally enacted on 25 June 1948, [2001] 28 U.S.C.S. $\S 41$. One of the judicial circuits covers not more than the District of Columbia and is not included in the numbering of circuits from one to eleven. The (thirteenth) Federal Circuit is composed of all federal judicial districts.

${ }^{178}$ See Court of First Instance, "1990 Discussion Paper", supra n. 11 at 177 ; M. A. Dauses, supra n. 5 at D 100; U. Everling, "System", supra n. 11 at N 12; P. J. G. Kapteyn, supra n. 23 at 148 149; T. Koopmans, supra n. 11 at $27-28$; V. Lipp, supra n. 22 at 330; J. L. Da Cruz Vilaça, supra n. 11 at 4; Members of the EC Section of the British Institute's Advisory Board chaired by The Rt. Hon. the Lord Slynn of Hadley, supra n. 11 at $103-104$

${ }^{179}$ For this concern, see e.g. T. Koopmans, supra n. 11 at 28. 
under Community law. ${ }^{180}$ Furthermore, a fully developed decentralised court structure would not correspond to the character of the institutional framework of the European Union in general: in contrast to the federal system of the United States, ${ }^{181}$ the execution of Community and European Union activities is mostly carried out by the institutions of the Member States, whereas the administrative and judicial powers of the entity established by the common legal order are strictly limited. Covering the Member States with a net of Community courts would thus create an imbalance between the limited executive power and the court struciure. ${ }^{182}$

This does not rule out decentralisation altogether. If separate specialised courts were to be created, their location could be chosen elsewhere in the European Union without causing any additional drawbacks. ${ }^{183}$ On the contrary, this would have the advantage of bringing the administration of justice geographically closer to where the disputes arise. A tribunal emerging from the Boards of Appeal of the OHIM, for instance, might be located at the seat of the agency in Alicante, Spain, whereas it seems preferable for the envisaged court with jurisdiction in disputes over Community patents to move near the headquarters of the European Patent Organisation in Germany. ${ }^{184}$

Finally, in order to bring justice nearer to the citizen in general, the CFI as the ordinary Community court of first instance could adopt a travelling system of sorts. The Federal Court of Canada is an example for the functioning of this idea. Although the judges of the Federal Court have to reside in or near the capital city, Ottawa, ${ }^{185}$ both the Trial Division and the Court of Appeal contained in the structure of the Federal Court may hold sittings at any location in Canada. ${ }^{186}$ In addition, the tasks of the registry of the

${ }^{180}$ See especially Court of First Instance, "1990 Discussion Paper", supra n. 11 at 177 ; U. Everling, "Justiz", supra n. 19 at 13; P. J. G. Kapteyn, supra n. 23 at $148-149$; Members of the EC Section of the British Institute's Advisory Board chaired by The Rt. Hon. the Lord Siynn of Hadley, supra n. 11 at $103-104$.

${ }^{181}$ For example, there are 94 district courts established by federal law below the United States Courts of Appeals that handle a large amount of civil and criminal cases; see R. H. Fallon, D. J. Meltzer \& D. L. Shapiro, supra n. 166 at $47-52$.

${ }^{182}$ See V. Lipp, supra n. 22 at 330, and U. Everling, "System", supra n. 11 at N 12 . See also the appreciation of Luxembourg as 'neutral ground' in Members of the EC Section of the British Institute's Advisory Board chaired by The Rt. Hon. the Lord Slynn of Hadley, supra n. 11 at 103.

${ }^{183}$ Decentralisation of this kind is suggested by W. van Gerven, supra n. 5 at 218.

${ }^{184} \mathrm{~A}$ note on the envisaged link between the Community patent system and the European Patent Organisation is found at 24, above.

${ }_{185}$ See Federal Court Act, 1970 , now R.S.C. 1985 c. F-7, Section 7 (1).

186 The Federal Court Act, ibid., provides in Section 15 (1) that 'any judge of the Trial Division may sit and act at any time and at any place in Canada for the transaction of the business of the Court or any part thereof and, when he so sits or acts, he constitutes the Court', and Section 16 
Federal Court are not only carried out by the principal office in Ottawa but also by 16 local offices across the country. ${ }^{187}$ Any party may use the office of his choice for any business to be done with the registry including the filing of documents for the proceedings. ${ }^{188}$ Some of the local offices of the registry host permanent courtrooms for sittings of the Federal Court.

For an enlarged CFI to avoid over-centralisation, establishing new infrastructure along these lines seems to be worthwhile considering. Offices of the registry and courtrooms could be located in different parts of the European Union, thus shortening the geographical distance to the parties - or more precisely in order to shorten the distance to individuals and corporations when bringing actions against Community institutions. Local offices of the CFI could operate efficiently in a limited number of languages, while the distribution of the case-load and the assignment of judges to different chambers (including in rotating the fields of specialisation) would remain as flexible as within a central institution. The many disadvantages of a system of regional Community courts would thus be avoided.

\section{E. Empowering the European Commission to decide treaty infringements}

It is mostly held that proceedings instituted against the Member States for failure to fulfil their obligations under Community law are appropriately allocated to the Court of Justice as the Communities' supreme court. ${ }^{189}$ In treaty infringement cases, the division of competence is involved, and the parties on both sides are constitutional agents of the European Union. In addition, the jurisdiction to impose financial sanctions in proceedings for failure to adhere to a previous judgment in a treaty infringement case is considered as touching upon politically sensitive issues.

However, a significant number of these actions do not raise any factual or legal difficulties, and thus, 'they do not bear upon the actual principle of distribution of powers

(3) reads: 'The place of each sitting of the Court of Appeal shall be arranged by the Chief Justice to suit, as nearly as may be, the convenience of the parties.'

${ }_{187}^{187}$ See Federal Court Rules, 1998, P.C. 1998-125, C. Gaz. 1998.II.424, Rule 17.

${ }^{188}$ See ibid., Rules 14 and 25.

189 See European Commission, supra n. 11 at 4; Working Party on the Future of the European Court of Justice, supra n. 8 at $25-26$; Members of the EC Section of the British Institute's Advisory Board chaired by The Rt. Hon. the Lord Slynn of Hadley, supra n. 11 at 59-60; U. Everling, "System", supra n. 11 at N 15; T. Koopmans, supra n. 11 at 27 ; C. O. Lenz, supra n. 11 at 13; R. Streinz \& S. Leible, supra n. 13 at 11. 
but merely upon the way in which effect is given to that distribution of powers. ${ }^{, 190}$ In particular, in many cases of failure to transpose a directive into national law within the specified time limits, the Member States implicated do not seriously dispute the actual treaty infringement but submit a defence as a matter of form only. ${ }^{191}$ Some contributors to the debate conclude, therefore, that a certain range of infringement proceedings should be transferred to the jurisdiction of the CFI. ${ }^{192}$

Another and, it is submitted, preferable way of relieving the Court of Justice of tasks which do not merit complex court proceedings is to give the European Commission the power to determine treaty infringements by way of decision following the model of Article 88 ECSC Treaty. ${ }^{193}$ Member States choosing to contest the decision would have to bring an action against the European Commission, thus enabling the Court of Justice to decide whether to suspend the act on a case-by-case basis ${ }^{194}$ and arguably deterring Member States from occupying the Court in hopeless cases.

It has been argued that a judicial function of this kind would not be in harmony with the status of the European Commission as a political body, especially as it may use the infringement procedure in order to assert a particular legal opinion vis-à-vis the Member States after having failed to convince them on the political level as members of the Council. ${ }^{195}$ It has been furthermore contended that neither the process of decisionmaking in the European Commission nor its basic administrative function would be compatible with the task to give judicial determinations of the rule of law. ${ }^{196}$ To this it is replied that the European Commission is in fact well acquainted with judicial functions and elaborate procedures as is shown, for instance, by its investigative powers, its competence to impose provisional measures and its role in the final decision in anti-dumping and anti-subsidy cases. ${ }^{197}$ Moreover, the only legal consequence of the decision of a

${ }^{190}$ Court of First Instance, "1990 Discussion Paper", supra n. 11 at 182.

191 See e.g. M. A. Dauses, supra n. 5 at D 77.

192 See Court of First Instance, "1990 Discussion Paper", supra n. 11 at 182, and M. A. Dauses, supra $\mathrm{n} .5$ at $\mathrm{D} 76-79$.

${ }^{193}$ In favour of this proposal: European Commission, supra n. 11 at 5 ; C. O. Lenz, supra n. 11 at 13; Working Party on the Future of the European Court of Justice, supra n. 8 at $25-26$.

${ }^{194}$ See Article 242 EC Treaty (ex Article 185 EC Treaty) and Article 157 EAEC Treaty.

${ }^{195}$ See especially M. A. Dauses, supra n. 5 at D $105-106$.

${ }^{196}$ See Members of the EC Section of the British Institute's Advisory Board chaired by The Rt. Hon. the Lord Slynn of Hadley, supra n. 11 at 64.

197 See Council Regulation (EC) No 384/96 of 22 December 1995 on protection against dumped imports from countries not members of the European Community. [1996] O.J. L 56/1, Articles 6 9, and Council Regulation (EC) No 2026/97 of 6 October 1997 on protection against subsidized imports from countries not members of the European Community, [1997] O.J. L 288/1, Articles 11 -15 . 
treaty infringement becoming final is the establishment of an actual failure to comply with Community law, all other consequences (such as financial sanctions or the rights of individuals flowing from that failure) being left for determination in proceedings before the courts.

If the European Commission were given the choice whether to decide the infringement itself or bring an action before the Court of Justice, it would be able to confine the use of its enhanced powers to appropriate cases. Where the alleged infringement is not undisputed as to fact and law but involves contentious and politically sensitive matters, the case could be brought directly to the Court of Justice, as an action by the Member State would be certain from the outset.

Lastly, a reform along these lines seems to be more effective and feasible than the proposition of introducing the option to institute proceedings against a Member State before one of its own courts: ${ }^{198}$ it is very doubtful which courts in the varied legal systems of the Member States could be designated for this function, not to mention the uncertainty concerning the legal effects of the courts' judgments within their own legal order and throughout the European Union. The efficiency of investigating and sanctioning treaty infringements by the Member States should rather be increased by way of improvements at the level of the Community institutions.

${ }^{198}$ For this proposition, see J.P. Jacqué \& J. H.H. Weiler, supra n. 84 at $198-199$. 


\section{Part 4 A model for the future}

Thus far, the emphasis has been on discussing different possible reforms in order to remedy increasingly unacceptable delays in the Community courts and adapt the whole judicial system to a rising case-load, the envisaged numerous accessions of new Member States and the qualitative change in the substantial law of the European Union. The impact of the growing significance of the protection of fundamental rights has been identified. The examined approaches to a reform of the Community court system follow notions such as: concentration on judicial tasks; refinement of the two-tier structure; differentiation of constitutional and administrative or ordinary matters; creation of three instances; specialisation; decentralisation; and even a devolution of sorts, involving either regional Community courts or new responsibilities of courts at the national level.

The arguments for or against individual proposals are repetitious to some extent. This is particularly the case where the function of the Community judiciary in general or as separated into different branches might be implicated in a particular suggestion for reform. In the present part, I will explore the attribution of judicial functions and infer a model for the evolution of the court system in the European Union in the future.

\section{A. The conflict of objectives}

The discussion of the reform proposals reveals a conflict that goes beyond the challenge of increasing the efficiency of the Community courts measured by their throughput and turnaround time, all the same while maintaining the quality of judicial decisions. ${ }^{1}$ It is the dialectics of general themes for the design of the court system: giving effective judicial protection to the interests of citizens and corporations as well as to those of the Member States and the Community institutions and guaranteeing the uniform interpretation and application of the law throughout the European Union. ${ }^{2}$ In the Community context, for

\footnotetext{
${ }^{1}$ These competing goals are taken as the point of departure by Members of the EC Section of the British Institute's Advisory Board chaired by The Rt. Hon. the Lord Slynn of Hadley, The Role and Future of the European Court of Justice (London: The British Institute of International and Comparative Law, 1996) at 4, and M. A. Dauses, "Empfiehlt es sich, das System des Rechtsschutzes und der Gerichtsbarkeit in der Europäischen Gemeinschaft weiterzuentwickeln?" (Report for the $60^{\text {th }}$ German Lawyers' Conference, 21 September 1994) in Ständige Deputation des Deutschen Juristentages, ed., Verhandlungen des Sechzigsten Deutschen Juristentags, vol. 1 (München: Beck, 1994) D 1 at D 73.

${ }^{2}$ The only authors to consider this conflict in such clarity seem to be P. J. G. Kapteyn, "The Court of Justice of the European Communities after the Year 2000" in D. Curtin \& T. Heukels, eds., Institutional Dynamics of European Integration - Essays in Honour of Henry G. Schermers, vol. 2
} 
the judiciary to be able to ensure the rule of law, the judicial system has to be designed so as to accomplish these tasks equally well.

\section{The rule of law and European integration}

Throughout the debate, the safeguarding of the unity of Community law is invoked repeatedly to argue for or against particular changes. Arguably, uniformity and coherence of the law are part of the rule of law in every legal order subscribing to this principle. But in the case of the European Union the task is specifically complex and central. This is founded on the way the Community system functions.

The Communities are a federal system in so far as the competence to set rules binding upon those to whom they are addressed is divided between separate entities, and common court enforces this division. ${ }^{3}$ The application of rules belonging to Community law is carried out by institutions at the level of both the Communities and the Member States. It follows that the task of securing the unity of the law has several dimensions: national institutions have to be urged to actually observe and apply the Community order; the effect of rules of Community law within the different legal systems must be the same in all circumstances; the interpretation of the law by different sections in the Community judiciary is to be as uniform as possible; and finally, major developments in Community law in general require supervision regarding their coherence and their successful operation within the national legal orders. This does not differ significantly from other federal structures. But what distinguishes the Communities is that the unity of the law in all of its dimensions is of utmost importance for the functioning of the system. As the European Union and the Communities do not have executive force comparable to a nation state, their continued existence depends on their being underpinned, without reservation, by a legal order. ${ }^{4}$ It is a constantly renewed task to ensure

(Dordrecht: Martinus Nijhoff, 1994) 135 at 145-146, and T. Koopmans, "The Future of the Court of Justice of the European Communities" (1991) 11 Yearbook of European Law 15 at 32.

${ }^{3}$ Compare e.g. the definition by K. Lenaerts, "Constitutionalism and the Many Faces of Federalism" (1990) 38 The American Journal of Comparative Law 205 at 263:

Federalism is present whenever a divided sovereignty is guaranteed by the national or supranational constitution and umpired by the supreme court of the common legal order. Both sovereigns enact laws with direct operation upon those to whom they are addressed.

${ }^{4}$ See especially T. Koopmans, supra n. 2, and U. Everling, "Justiz im Europa von Morgen" [1993] Deutsche Richterzeitung 5 at 5 . See also Court of Justice, Report on Certain Aspects of the Application of the Treaty on European Union (22 May 1995), reprinted in German [1995] Zeitschrift für Europäisches Gemeinschaftsrecht 316 at 318 , for a statement on the significance of the uniform application and interpretation of the law with respect to the operation of the common market, a key activity of the European Community. While reaffirming this analysis, the Court has 
the effectiveness of that legal order and to provide for its proper interaction with the legal systems of the Member States. ${ }^{5}$

The above statements essentially reflect an integrationist view of the role of Community law. This perspective has been criticized as underpinning inappropriate judicial activism wherever it was thought to be detected as the sole or principal basis for the jurisprudence of the Court of Justice. ${ }^{6}$ Far from trying to determine the correct jurisprudential approach to Community law, for the discussion of institutional reforms, including that of the judiciary, the Member States' continued determination to achieve an ever closer union among the peoples of Europe must be assumed, and also that it is their wish that the institutional structure is adequately designed for promoting the goals which are set out in the Treaties.

The authors of the Treaties have originally framed the rule of law as the principal vehicle for the Community institutions to use in fulfilment of their purpose. Even if the Member States had not been aware of the effect this would eventually have on their legal systems (and thus on their sovereignty), ${ }^{7}$ they have never changed their stance so as to revise the Community system. From this perspective, the role of Community law is indeed insolubly linked to European integration and so is the function of the courts, if it is

recently stated that the unity of Community law... constitutes one of the cornerstones of the Union... and will become still more vital and vulnerable as a result of enlargement of the Union'; see Court of Justice \& Court of First Instance, The Future of the Judicial System of the European Union (Proposals and Reflections) (Discussion Paper, 10 May 1999) <http://curia.eu.int/en/txt/ intergov/ave.pdf> at 22 and 26.

${ }^{5}$ See V. Lipp, "Entwicklung und Zukunft der Europäischen Gerichtsbarkeit" [1997] Juristenzeitung 326 at 331.

${ }^{6}$ See e.g. H. Rasmussen, On Law and Policy in the European Court of Justice (Dordrecht: Martinus Nijhoff, 1986); T. C. Hartley, The Foundations of European Community Law, $4^{\text {th }}$ ed. (Oxford: Oxford University Press, 1998) 78 - 81; idem, "The European Court, Judicial Objectivity and the Constitution of the European Union" (1996) 112 The Law Quarterly Review 95. Contra e.g. M. Cappelletti, "Is the European Court of Justice 'Running Wild'?" (1987) 12 European Law Review 3; The Rt. Hon. The Lord Howe of Aberavon, "Euro-Justice: Yes or No?" (1996) 21 European Law Review 187; T. Tridimas, "The Court of Justice and Judicial Activism" (1996) 21 European Law Review 199; A. Arnull, "The European Court and Judicial Objectivity: A Reply to Professor Hartley" (1996) 112 The Law Quarterly Review 411; M. Shapiro, "The European Court of Justice" in P. Craig \& G. de Búrca, eds., The Evolution of EU Law (Oxford: Oxford University Press, 1999) 321 at $339-340$.

${ }^{7}$ This is acknowledged also by commentators who do not share the criticism of judicial activism; see e.g. M. Shapiro, supra n. 6, at 330-331, and R. Craufurd Smith, "Remedies for Breaches of EU Law in National Courts: Legal Variation and Selection" in P. Craig \& G. de Búrca, supra n. 6, 287 at $287-290$. See also G. F. Manchini, "The Making of a Constitution for Europe" (1989) 26 Common Market Law Review 595. 
for them to ensure the rule of law, or as one commentator has formulated, "to strive for the objectivity of known rules impartially administered ${ }^{\prime 8}$ in the European Union.

The task to give judicial determinations of the rule of law in disputes involving matters of Community law is mainly entrusted to the courts of the Member States - at least so according to the number of cases. This is in keeping with the general principle of limited empowerment of the Communities, and it is the way the notion of decentralisation, that is to take decisions 'as closely as possible to the citizen', 9 is translated into the institutional structure. As a counterbalance, it is one of the fundamental tasks of the judiciary at the Community level to ensure that the rule of law is uniformly applied by the national courts and that new developments in the Community legal order meet the requirements of consistency and operability in all of the participating legal systems.

The power given to the Community judiciary in order to discharge this task is contained in the preliminary rulings procedure. The co-operative character of the procedure is compared favourably to mechanism based on a hierarchical relationship in the way it enhances loyalty of the domestic courts and their becoming agents of the supreme legal order. ${ }^{10}$ Moreover, the system of preliminary references has been identified as a tool of legal integration with a drive of its own, as it involves the widest range of participants such as private litigants, their lawyers and even lower courts in opposition to the national courts they are subordinate to, ${ }^{11}$ and as it motivates them effectively to use Community law and its procedures in the pursuit of their autonomous interests. ${ }^{12}$ This

${ }^{8}$ D. Edward, "What Kind of Law Does Europe Need? The Role of Law, Lawyers and Judges in Contemporary European Integration" (1998/1999) 5 Columbia Journal of European Law 1 at 14.

${ }^{9}$ Article 1 para 2 TEU (ex Article 1 para 2 TEU).

${ }^{10}$ Based on this analysis, Jeffrey C. Cohen suggests extending the use of certification known in the American judicial system so as to enable state courts to certify questions to the Supreme Court of the United States and avoid confrontation with the Supreme Court's certiorari jurisdiction; see "The European Preliminary Reference and U.S. Supreme Court Review of State Court Judgments: A Study in Comparative Judicial Federalism" (1996) 44 The American Journal of Comparative Law 421.

${ }^{11}$ See e.g. A.-M. Burley \& W. Mattli, "Europe before the Court: A Political Theory of Legal Integration" (1993) 47 International Organization 41; W. Mattli \& A.-M. Slaughter, "Revisiting the European Court of Justice" (1998) 52 International Organization 177; K. Alter, "Explaining National Court Acceptance of European Court Jurisprudence: A Critical Evaluation of Theories of Legal Integration" in A.-M. Slaughter, A. Stone Sweet \& J. H. H. Weiler, eds., The European Court and National Courts - Doctrine and Jurisprudence (Oxford: Hart, 1998) 227; A. Stone Sweet \& T. L. Brunell, "Constructing a Supranational Constitution: Dispute Resolution and Governance in the European Community" (1998) 92 American Political Science Review 63.

${ }^{12}$ As such, the finding does not determine whether the judiciary in the European Union, in particular the Court of Justice, carries legal integration further than the Member States accept on the basis of national interest calculations ('spill-over'), or whether the Court of Justice merely acts in the interest of the national governments; for recent discussion see e.g. G. Garrett, R. D. Kelemen \& H. Schulz, "The European Court of Justice, National Governments, and Legal Integration in the 
confirms in essence the success of the idea of private enforcement of Community law and additional supervision of the Member States from the inside, which the Court of Justice set out when establishing the direct effect and supremacy of the newly created legal order of the Communities. ${ }^{13}$

It follows from all of the above that the system of preserving the unity of the law by way of interlocutory procedures and co-operation between the courts is to function properly in order for the Community judicial system to fulfil one of its fundamental tasks. Any restructuring of the courts in the European Union has to be largely measured by this requirement.

\section{The rule of law and the protection of individual rights}

The requirement of judicial control... reflects a general principle of law which underlies the constitutional traditions common to the Member States. That principle is also laid down in Articles 6 and 13 of the European Convention for the Protection of Human Rights and Fundamental Freedoms of 4 November $1950 .^{14}$

It was stated above that the Court of Justice, in the judgment from which the passage is taken, has established the right to an effective judicial remedy before the national courts. This applies in so far as Community law reaches into the legal systems of the Member States. However, there can be no doubt that the effective judicial protection of individual interests is also part of the rule of law as applying to the institutions of the Communities themselves. ${ }^{15}$

So far as the Member States and the Community institutions are concerned, it has been clear since the beginning that the Community judiciary is to protect particular interests and prerogatives. From perspective of these parties, the Court of Justice was created in order to guard the division of powers, to control the validity of norms in view of rules of a higher order, and in general to determine the law in conflicts between principal

European Union" (1998) 52 International Organization 149; R. D. Brewster, "Calling the Tune or Following the Lead: The European Court of Justice in European Policy Making" (1998) 13 Tulane European and Civil Law Forum 1; K. Alter, "The European Union's Legal System and Domestic Policy: Spillover or Backlash?” (2000) 54 International Organization 489.

${ }^{13}$ The relevant passage from Court of Justice, Judgment of 5 February 1963, Van Gend en Loos $\checkmark$ Nederlandse Administratie der Belastingen, Case 26/62 [1963] E.C.R. 1, is quoted at 64, above. See also P. Craig, "Once Upon a Time in the West: Direct Effect and the Federalization of EEC Law" (1992) 12 Oxford Journal of Legal Studies 453 at $454-458$.

${ }^{14}$ Court of Justice, Judgment of 15 May 1986, Johnston v Chief Constable of the Royal Ulster Constabulary, Case 222/84 [1986] E.C.R. 1651 at 1682.

${ }^{15}$ On such grounds, the Court ruled less than a month before delivering the abovementioned judgment that an action for annulment could be brought against a resolution adopted by the European Parliament; see Court of Justice, Judgment of 23 April 1986, Les Verts v Parliament, Case 294/83 [1986] E.C.R. 1339 at 1365. 
(the Member States) and agent (mainly the Commission/High Authority) as a 'predetermined third party dispute resolver'. ${ }^{16}$ This can be understood as the typical role of a constitutional court. ${ }^{17}$

In contrast, the protection of the interests of private parties, and in particular the protection of fundamental rights, had to evolve gradually. The standing of individuals of all sorts to bring actions against Community acts emerged only with the EEC and EAEC Treaties. The same can be said about the use of preliminary references as a procedure affording individuals judicial protection vis-à-vis the Communities. After the recognition of the principle of respect for fundamental rights in the jurisprudence of the Court of Justice, the textual implementation of such rights in the Community legal order has had a long way to go and is not fully achieved yet.

However, the Community institutions and the Member States have repeatedly confirmed their attachment to the rule of law as including the protection of the rights and interests of individuals. ${ }^{18}$ Given the Member States' common legal traditions, this must be considered a necessary precondition of creating a federal or federative entity vested with powers that stem from either the limitation of national sovereignty or the transfer of powers from the participating states. It follows that the requirements of an effective distribution of justice in cases concerning the protection of citizens and undertakings against illegal measures adopted by the Community institutions are of particular significance for the design of the judicial system. As guidelines they are equally important not only to the proper functioning of constitutional dispute resolution but also to the requirements of an effective system of preliminary references.

\footnotetext{
${ }^{16}$ M. Shapiro, supra n. 6 , at 327.

${ }^{17}$ See e.g. J. Mischo, "Un Rôle nouveau pour la Cour de Justice?" (1990) 342 Revue du Marché Commun 681 at $681-684$; J. Rinze, "The Role of the European Court of Justice as a Federal Constitutional Court" [1993] Public Law 426; G. C. Rodríguez Iglesias, "Der Gerichtshof der Europäischen Gemeinschaften als Verfassungsgericht" [1992] Europarecht 225.

${ }^{18}$ See e.g. the $4^{\text {th }}$ Recital and Article 2 line 3 of the TEU (ex Article B line 3 TEU). See also the $14^{\text {th }}$ Recital of Council Decision 88/591/ECSC, EEC, Euratom of 24 October 1988 establishing a Court of First Instance of the European Communities, [1988] O.J. L 319/1 and [1989] O.J. L 241/4 (corrigenda), stating that a second court was to be created in order to improve the judicial protection of individual interests'. A long time before Article 6 (2) TEU (ex Article F (2) TEU) and the Charter of Fundamental Rights of the European Union were drawn up, the European Parliament, the Council and the European Commission had issued a declaration acknowledging the importance they attached to the respect for fundamental rights; see Joint Declaration by the European Parliament, the Council and the Commission done on 5 April 1977, [1977] O.J. C $103 / 1$.
} 


\section{B. Reconciling competing principles}

The judicial system of the European Union is to provide for effective judicial protection in each case of infringement of an individual right; it must serve as a mechanism for the resolution of disputes between constitutional agents, especially where the division of competence is called in question; and it must comprise a procedure in which the courts of the Member States and the Community judiciary co-operate effectively in order to ensure the unity of the law and contribute to the consistent development of the common legal order. These requirements coincide with notions found in the case law of the Court of Justice that have been analysed as delineating the 'essential functions' of the courts in the European Union. ${ }^{19}$ Unlike jurisprudential emphases, however, the model for a judicial system must reconcile the guidelines in a single structure. It can be inferred from the discussion in Part 3 that depending on the function underlying a particular competence of the Community courts, different ideal structures emerge.

For the preliminary reference procedure to have the preferable effects it can thus be concluded:

- rulings on questions from national courts must be given exclusively by the Community judiciary;

- all domestic courts should be able to take part in the dialogue, not only those of higher instance;

- each court should co-operate directly with the Community judiciary, not through national intermediaries; the language of communication should not differ from the language used in the domestic forum;

- every acceptable question from a national court is to be answered; there should be no selection as to the importance of a question from the perspective of Community law;

- in principle, the jurisdiction to rule on preliminary references should be vested in one (central) Community court;

- on an exceptional basis, predefined specialised categories of questions may be allocated to other sections of the Community judiciary; the gain from expertise must outweigh the drawback of the possibility of inconsistencies;

\footnotetext{
${ }^{19}$ See P. R. Dubinsky, "The Essential Function of Federal Courts: The European Union and the United States Compared" (1994) 42 The American Journal of Comparative Law 295.
} 
- there is no appeal, but the Community court of general jurisdiction in preliminary references must retain a supervisory function allowing it, if necessary, to reestablish the consistent interpretation of the law;

- the court of general jurisdiction in preliminary references should consist of one judge per Member State;

- the court should sit in chambers or in limited plenary formations according to the significance of the question referred; it may choose to refer a case to the grand plenum on grounds of extraordinary importance;

- through its case law, the court may encourage national courts to apply Community law without reassuring themselves by way of a preliminary reference; for doing so, the Community court must consider the state of legal integration and the varied experience of the courts of the Member States in applying provisions of the Community legal order;

- any domestic court must remain under the obligation to ask for a preliminary ruling, if it seriously doubts the validity of a rule of Community law it would otherwise have to apply.

In summary, these guidelines match almost perfectly the present function of the Court of Justice as a court according to Article 234 EC Treaty and Article 150 EAEC Treaty, and the principles of the Court's composition would not have to be altered dramatically even at the prospect of numerous accessions of new Member States. Preserving for the Court of Justice as a court the jurisdiction to give preliminary rulings would also correspond to any appellate jurisdiction or power to rule on applications in the interest of the law that might be conferred on it. In all of these cases, the Court of Justice acts as the ultimate interpreter of Community law, and in doing so it has to rely on its singularity as the supreme court of the European Union.

Different structural guidelines follow from the discussion as concerns the judicial protection of individual interests:

- protection against the illegal execution of Community law by institutions of the Member States is to be sought before national courts supported by the Court of Justice through the preliminary rulings procedure; these courts must ensure the right to an effective judicial remedy;

- in this context, the enforcement of fundamental rights should be preserved for the courts of the Member States and ultimately the European Court of Human 
Rights, except where the alleged infringement originates in a measure adopted by the Communities or the European Union;

- private parties must have standing to bring actions against any binding Community or European Union measure adversely affecting them, regardless of the formal status of the act;

- in principle, jurisdiction in these direct actions must be conferred on a single unitary Community court;

- the court of general jurisdiction in direct actions by private parties is to sit in small chambers or may be constituted by a single judge in order to provide for efficient procedures and the capacities for an adequate evaluation of the factual background;

- chambers formally constituted or divisions comprising several chambers should be specialised in order to gain from rationalization and expertise; a case may be referred to the plenary session for the purpose of forestalling obvious inconsistencies in the case law of different chambers;

- the court of general jurisdiction in direct actions by private parties should have infrastructure in different parts of the European Union; while its seat may be in Luxembourg, sittings are to be held wherever it is convenient with respect to the residence of the parties;

- the number of judges in the court is to be determined solely by the objective needs, as long as there is at least one judge from each Member State;

- below the court, there should be a special tribunal for the particular category of staff cases; from the decisions of this tribunal appeal on points of law only may lie to a specialised chamber of the court;

- as another exception, jurisdiction in disputes over patents, trade marks, designs and plant variety rights should be vested exclusively in a specialised court at the level of the court of general jurisdiction in direct actions by private parties;

- the Boards of Appeal of the OHIM and the CPVO may be incorporated as a lower tier in the court with jurisdiction in intellectual property law or become a separate expert tribunal from whose decisions appeal on points of law only may lie to that court. $^{20}$

\footnotetext{
${ }^{20}$ As long as the Community patent system is not established, appeals against the tribunal's decisions in cases involving Community trade marks, designs and plant variety rights will have to be brought before the court of general jurisdiction in direct actions by private parties.
} 
It follows from these principles that some changes would have to be made to the powers, the composition and the organisation of the $\mathrm{CFl}$, if it were to live up to the model court of general jurisdiction in direct actions by private parties. On the other hand, the function of the Court of Justice as a court in the composition outlined above must be confined, in this context, to hearing appeals against decisions of the CFI so adapted. ${ }^{21}$ In addition, in order to keep the case-load in the single supreme court of the European Union at a workable level, appeals must be filtered on the basis of an admissibility-test or by way of discretionary selection by the Court of Justice. In both cases, the filtering criteria would result in an assessment of the significance of the appeal from the perspective of Community law, but particular importance must be attached to the principle of the respect for fundamental rights. In order to reflect the significance of the role of the CFI within this structure, it would have to be given the status of an autonomous judicial institution of the Communities. ${ }^{22}$ Moreover, in cases commenced before a tribunal below the CFI or below a court with jurisdiction in intellectual property law or in those commenced before the lower tier of that court, the Court of Justice should in principle not rule at third instance. The only form of appeal in these cases should require the claim that fundamental rights are infringed by a previous judgment.

Broad locus standi in a lower tier which is decentralised and sufficiently specialised, strictly limited access to a supreme court also co-operating with the courts of the Member States - this is the key to reconciling the requirements of the protection of individual rights on the one hand and of effectively securing the unity of Community law on the other. From the perspective of the individual litigant, the Court of Justice as a court will not anymore ensure that all errors are corrected. However, a filtering mechanism that takes into account that the effective protection of fundamental rights is the basis for the legitimacy of a legal order will provide for access to the highest Community court in all appropriate cases. From the point of view of the uniform application and consistent development of the law, the limitation on appeals will be sufficiently remedied by way of a generally applicable pourvoi dans lintérêt de la loi to be exercised by the European Commission or the advocates general in the Court of Justice.

Finally, the model must consider the task of the Community courts to resolve interinstitutional conflicts and those between Member States and between Member

${ }^{21}$ The Court of Justice as a court would also hear appeals against decisions of the court with jurisdiction in intellectual property law.

${ }_{22}$ The same applies to a court with as broad a jurisdiction in intellectual property law as recommended above. 
States and Community institutions. In opposite to the principles following from each of the other two essential functions, these cases do not require any separate and unitary structural solution.

As far as infringement proceedings under Article 226 EC Treaty and Article 141 EAEC Treaty are concerned, it was argued above that the European Commission should be empowered to decide the failure of a Member States to comply with Community law. Jurisdiction in actions brought by Member States against such a decision of the European Commission and also in any other action relating directly to treaty infringements ${ }^{23}$ should be vested in the Court of Justice as the supreme court of the European Union. The same applies to opinions according to Article 300 (6) EC Treaty and Article 103 (3) EAEC Treaty requested in respect of the conclusion of international agreements. All of the abovementioned procedures are most likely to call into question the division of competence or to involve the Member States' mutual obligations originally entered into by way of a treaty of international law. They warrant, therefore, being assigned to the court at the top of the Community judicial system and composed according to the principle of representation.

As concerns other direct actions brought by the Member State or by institutional applicants in order to challenge the legality of an act of a Community institution or to establish its failure to act in infringement of the Treaties, it can be concluded from the discussion in Part 3 that only those of constitutional significance should be heard by the supreme court of the European Union. The filtering of appeals according to the mechanism generally applied was identified as being the most feasible way to select issues of constitutional nature. This means that jurisdiction at first instance in all of these actions must be conferred on another court below the Court of Justice. Many of the cases concerned raise the same issues as direct actions brought by private parties, and some equally require sufficient capacities for the evaluation of the factual background. Jurisdiction at first instance should thus be vested in the $\mathrm{CFI}$ as a court of general jurisdiction in direct action in the composition outlined above.

\footnotetext{
${ }^{23}$ See e.g. Articles 227, 228 (2), 237 and 239 EC Treaty.
} 


\section{Conclusion - The Treaty of Nice}

The model described in the preceding part in essence sets out a two-tier structure of Community courts (with narrow exceptions) and recommends the retention of the successful preliminary rulings procedure involving all the courts of the Member States. The higher tier is necessarily confined to the function of ensuring the unity of the law and overseeing the development of the legal order in principled cases, especially those of constitutional nature or bearing upon the respect for fundamental rights. The function of the lower tier is to provide effective judicial protection against illegal acts of the Communities and of the European Union - for citizens and corporations and for the Member States and Community institutions alike. In the following, this model will be briefly compared with the reform of the judicial system as intended by the Treaty of Nice.

If the Treaty of Nice enters into force, all the provisions on the judicial structure and court organisation contained in the EC and EAEC Treaties will be revised. ${ }^{1}$ In contrast, no changes will take effect regarding Community jurisdiction in general and as concerns the powers of the Court of Justice (as a whole). ${ }^{2}$ The system of preliminary references will thus be left unaltered, but this will also apply to the inconsistent limitations according to Article 68 (1) and (2) EC Treaty. It follows furthermore that the lack of judicial protection against acts adopted under the European Union institutional framework will persist, and so will the uncertainty surrounding a possible reaction on the part of the European Court of Human Rights.

The Treaty of Nice recognises the $\mathrm{CFI}$ as an autonomous judicial organ with original jurisdiction. ${ }^{3}$ However, the CFI will neither be included in the list of Community institutions according to Article 7 (1) EC Treaty (ex Article 4 (1) EC Treaty) and Article 3 (1) EAEC Treaty, nor will the provisions conferring jurisdiction on the 'Court of Justice' be adapted accordingly. Instead, revised Article 225 EC Treaty will lay down the jurisdiction of the CFI as follows: ${ }^{4}$

\footnotetext{
${ }^{1}$ See Treaty of Nice, Article $2(26)-(35)$ and Article $3(8)-(16)$.

2 Sole exception is a revision of the standing rules with respect to the European Parliament under Article 230 para 2 and para 3 EC Treaty (ex Article 173 para 2 and para 3 EC Treaty) and the corresponding paragraphs of Article 146 EAEC Treaty: the European Parliament will be accorded standing before the Court of Justice and the CFI in the same way as the Member States, the Council and the European Commission.

${ }^{3}$ It will be stated in Article 220 para 1 EC Treaty and in identical terms in Article 136 para 1 EAEC Treaty that both ' $[\mathrm{t}] \mathrm{he}$ Court of Justice and the Court of First Instance, each within its jurisdiction, shall ensure that in the interpretation and application of this Treaty the law is observed.'

${ }^{4}$ See also revised Article 140a EAEC Treaty.
} 
1. The Court of First Instance shall have jurisdiction to hear and determine at first instance actions or proceedings referred to in Article 230,232, 235, 236 and 238, with exception of those assigned to a judicial panel and those reserved in the Statute for the Court of Justice. The Statute may provide for the Court of First Instance to have jurisdiction for other classes of action or proceeding.

Decisions given by the Court of First Instance under this paragraph may be subject to a right of appeal to the Court of Justice on points of law only, under the conditions and within the limits laid down by the Statute.

3. The Court of First Instance shall have jurisdiction to hear and determine questions referred for a preliminary ruling under Article 234, in specific areas laid down by the Statute.

Where the Court of First Instance considers that the case requires a decision of principle likely to affect the unity or consistency of Community law, it may refer the case to the Court of Justice for a ruling.

Decisions given by the Court of First Instance on questions referred for a preliminary ruling may exceptionally be subject to review by the Court of Justice, under the conditions and within the limits laid down by the Statute, where there is a serious risk of the unity or consistency of Community law being affected.

The Council will be empowered to attach to the $\mathrm{CFI}$, by way of a procedure resembling the creation of the CFI itself, so-called 'judicial panels' with jurisdiction to hear and determine at first instance certain specific categories of cases. ${ }^{5}$ The members of these panels have to possess the ability required for appointment to judicial office. ${ }^{6}$ An appeal, which may be confined to points of law only, ${ }^{7}$ will lie from the decision of a panel to the Court of First Instance. Revised Article 225 (2) will provide: ${ }^{8}$

The Court of First Instance shall have jurisdiction to hear and determine actions or proceedings brought against decisions of the judicial panels set up under Article 225a.

Decisions given by the Court of First Instance under this paragraph may exceptionally be subject to review by the Court of Justice, under the conditions and within the limits laid down by the Statute, where there is a serious risk of the unity or consistency of Community law being affected.

Contrary to the model here argued for, the authors of the Treaty have thus opted for the general possibility to establish a three-tiered structure. Although the speedy creation of a judicial panel for staff cases seems certain, ${ }^{9}$ one may identify flexibility as the major

\footnotetext{
${ }^{5}$ See new Article 220 para 2, new Article 225a EC Treaty and the corresponding provisions to be inserted in the EAEC Treaty.

${ }_{7}^{6}$ See new Article 225a para 4 EC Treaty.

${ }^{7}$ See new Article 225a para 3 EC Treaty.

${ }^{8}$ See also revised Article $140 a$ (2) EAEC Treaty.

${ }^{9}$ A declaration adopted by the Conference of the Representatives of the Governments of the Member States calls on the Court of Justice and the European Commission to prepare a draft decision to that end as swiftly as possible; see Declaration (No. 16) on Article 225a of the Treaty
} 
objective of the reform as a whole: it will be left to future Council decisions amending the Statute of the Court of Justice to determine the range of jurisdiction of the CFI and the rules on appeals and other forms of review concerning judgments given by the CFI at first or second instance. ${ }^{10}$ These questions are still largely unresolved, and the Conference of the Representatives of the Governments of the Member States has restricted itself to a number of declarations reflecting the new structure. Two of them shall be reproduced here:

The Conference calls on the Court of Justice and the Commission to give overall consideration as soon as possible to the division of competence between the Court of Justice and the Court of First Instance, in particular in the area of direct actions, and to submit suitable proposals for examination by the competent bodies as soon as the revised Treaty enters into force."

The Conference considers that the essential provisions of the review procedure in Article 225 (2) and (3) should be defined in the Statute of the Court of Justice. Those provisions should in particular specify:

- the role of the parties in proceedings before the Court of Justice, in order to safeguard their rights;

- the effect of the review procedure on the enforceability of the decision of the Court of First Instance;

- the effect of the Court of Justice decision on the dispute between the parties. ${ }^{12}$

For the time being, the new Statute of the Court of Justice will provide that the Court of Justice as a court shall retain jurisdiction in actions brought by the Member States and the Community institutions including the ECB. ${ }^{13}$ Subject to future amendments of the Statute, the First Advocate General will be enabled to institute the review procedure for appeal decisions and preliminary rulings given by the CFI before the Court of Justice. ${ }^{14}$

It can be inferred from all of the above that the authors of the Treaty chose to draft flexible provisions in order to overcome a certain amount of indecision. Moreover, they have laid out a framework for reform despite the lack of precise solutions for all the identified drawbacks. A particular problem is the possibility of an unrestricted transfer of

establishing the European Community, Final Act of Nice done on 26 February 2001, [2001] O.J. C $80 / 70$ at 80 .

${ }^{10}$ According to revised Article 245 EC Treaty and revised Article 160 EAEC Treaty, the Council will be able to amend the Statute of the Court of Justice by way of unanimous decision, except for the provisions on the status of the judges and advocates general of the Court.

${ }_{11}$ Declaration (No. 12) on Article 225 of the Treaty establishing the European Community adopted by the Conference of the Representatives of the Governments of the Member States, Final Act of Nice, supra n. 9 at 79.

${ }_{12}$ Declaration (No. 13) on Article 225 (2) and (3) of the Treaty establishing the European Community adopted by the Conference of the Representatives of the Governments of the Member States, Final Act of Nice, supra n. 9 at 79.

${ }_{13}$ See Article 51 Statute of the Court of Justice (Nice).

${ }^{14}$ See Article 62 Statute of the Court of Justice (Nice). 
certain categories of preliminary references to the jurisdiction of the CFI. It is equally disturbing that the Treaties will not prohibit any broader use of judicial bodies from whose decisions appeal will lie to the CFI ruling at second instance. ${ }^{15}$ The most regrettable failure, however, concerns the lack of courage to reform the standing rules in order to provide for adequate access to the CFI and relieve the Court of Justice as a court of a significant number of preliminary references. A reform following the analysis of essential functions of the Community judiciary would have avoided these insufficiencies, and it would have produced a principled structure to be appropriately included in the provisions of the Treaties.

Apart from the fact that the Treaty of Nice puts an emphasis on the attachment of judicial panels to the $\mathrm{CFI}$, the new provisions on the composition of the courts take a few steps in the direction of the model here presented. Revised Article 221 para 1 EC Treaty will explicitly relate the number of judges in the Court of Justice as a court to the number of Member States of the European Union. ${ }^{16}$ The Court of Justice will generally sit in chambers of three or five judges or in a Grand Chamber consisting of eleven judges. ${ }^{17}$ On an exceptional basis, the Court of Justice may decide to refer a case to the full Court, ${ }^{18}$ which will have a quorum of eleven judges. ${ }^{19}$

The CFI, in contrast, will comprise at least on judge per Member State, with the actual size of the membership being determined by the Statute of the Court of Justice. ${ }^{20}$ It will sit in chambers of three or five judges, ${ }^{21}$ and the assignment of cases to the chambers will be governed by the Rules of Procedure of the CFI. ${ }^{22}$ This is currently the law under Article 2 (4) of Council Decision 88/591/ECSC, EEC, Euratom of 24 October $1988,{ }^{23}$ but according to new Article 224 para 5 EC Treaty, the Rules of Procedure adopted by the CFI in agreement with the Court of Justice will have to be approved only

\footnotetext{
${ }^{15}$ In contradiction to this openness, the Treaty of Nice will not change the name of the CFI that indicates that it has merely jurisdiction at first instance.

${ }^{16} \mathrm{See}$ also revised Article 137 para 1 EAEC Treaty.

${ }^{17}$ See revised Article 221 para 2 EC Treaty and revised Article 137 para 2 EAEC Treaty; see also Article 16 Statute of the Court of Justice (Nice).

${ }^{18}$ See Article 16 para 5 Statute of the Court of Justice (Nice). Also, the Statute will prescribe that the Court of Justice sit in plenary session in some very exceptional procedures, see Article 16 para 4 Statute of the Court of Justice (Nice).

${ }_{19}$ Article 17 para 4 Statute of the Court of Justice (Nice).

${ }^{20}$ See new Article 224 para 1 EC Treaty and new Article 140 para 1 EAEC Treaty.

${ }^{21}$ See Article 50 para 1 Statute of the Court of Justice (Nice).

22 See Article 50 para 2 Statute of the Court of Justice (Nice).

${ }^{23}$ Council Decision 88/591/ECSC, EEC, Euratom of 24 October 1988 establishing a Court of First Instance of the European Communities, [1988] O.J. L 319/1 and [1989] O.J. L 241/4 (corrigenda).
} 
by a qualified majority in the Council. ${ }^{24}$ Therefore, it might be easier for the CFI to formally constitute its chambers and to achieve a certain specialisation. The Rules of Procedure will also determine the cases in which the CFI is to sit in plenary session or be constituted by a single judge, and they may provide for the creation of a Grand Chamber. ${ }^{25}$ The CFI might thus choose to establish the possibility of referring a case to the plenary session or the Grand Chamber in order to ensure consistency in the case law of different ordinary chambers.

The Treaty of Nice does not take up the idea of decentralised infrastructure and travelling judges. To some extent, this may be linked to the difficulties of the Member States to agree on the seats of Community institutions in general, and to convince Luxembourg in particular not to insist that judicial institutions be located exclusively on its territory. ${ }^{26}$ However, the Conference of the Representatives of the Governments of the Member States took note of a unilateral declaration by Luxembourg that

[w]ithout prejudice to the Decision of 8 April 1965 and the provisions and possibilities contained therein regarding the seats of institutions, bodies and departments to be set up, the Luxembourg Government undertakes not to claim the seat of the Boards of Appeal of the Office for Harmonisation in the Internal Market (trade marks and designs), which will remain in Alicante, even if the Boards were to become judicial panels within the meaning of Article 220 of the Treaty establishing the European Community. ${ }^{27}$

It is to be expected that this will remain the only notion of decentralisation in the judicial structure for the foreseeable time.

Finally, as the declaration by Luxembourg indicates, the Boards of the OHIM might soon be transformed into an independent judicial body. At present, there is no indication that the Boards of the CPVO will share the same fate. From the point of view of a coherent judicial structure, this is difficult to understand, as it determines whether or not the Court of Justice will have appellate jurisdiction. However, if Luxembourg insists on locating any judicial panel for Community plant variety rights on its territory, chances will be dim.

It also seems that the authors of the Treaty have opted against any pooling of jurisdiction in intellectual property law. If judicial panels for actions concerning trade marks, designs or plant variety rights are created, they will be attached to the CFI. In contrast, jurisdiction in disputes over industrial property, in particular the striven-for

\footnotetext{
${ }^{24}$ See also new Article 140 para 5 EAEC Treaty.

${ }^{25}$ See Article 50 para 2 and para 3 Statute of the Court of Justice (Nice)

${ }^{26}$ A discussion of the provisions concerning the seat of the Communities' judicial bodies is found at $4-5$, above.

${ }_{27}$ Declaration (No. 1) by Luxembourg of which the Conference of the Representatives of the Governments of the Member States took note, Final Act of Nice, supra n. 9 at 87.
} 
Community patent, will be separately governed by new Article 229a EC Treaty. According to this provision, the Council will be empowered to recommend to the Member States the adoption of provisions conferring on the Court of Justice, to the extent determined in the recommendation, jurisdiction in disputes relating to Community acts which establish industrial property rights. Instead of indicating any progress in the effort to set up a patent system that includes an adequate judicial structure, the new Article, by binding any such measures to another ratification process, reflects how contentious the Community patent is among the Member States.

In summary, while there is some agreement with the model here argued for, the Treaty of Nice will introduce a number of notions to the system of Community courts that cannot be commended. Most surprisingly, however, the Treaty fails to give a clear direction as to how the judicial system in the European Union will be structured in the long term. This is regrettable, as the Treaty has been drafted at a time of unique understanding as to the need for reform. Now, the provisions of the EC and EAEC Treaties will be open to gradual adaptations, and it will be difficult for a judicial architecture according to principles to prevail. 